\title{
ARTICLES \\ TAX AND DISABILITY: ABILITY TO PAY AND THE TAXATION OF DIFFERENCE
}

\author{
THEODORE P. SETO ${ }^{\dagger}$ \\ SANDE L. BUHAI ${ }^{\dagger+}$
}

Although people with disabilities make up some $20 \%$ of the American population, scholars have largely ignored U.S. tax provisions of particular relevance to them. This Article undertakes the first such systematic study. In the process, it reexamines disability theory, tax theory, and the mechanical structure of the individual income tax system. Disability theory has changed dramatically over the past century, to the point that many tax rules important to people with disabilities are no longer justified by modern disability theory. Standard tax theory turns out to be inadequate to deal with the problems of people with disabilities because, consistent with its utilitarian origins, standard tax policy analysis generally assumes that taxpayers are identical except with respect to income; as a result, it lacks the capacity to deal with other individual differences in ability to pay. The failure of tax theory to deal adequately with ability to pay, in turn, has placed serious strains on the mechanical structure of the individual income tax system as a whole, which has become increasingly incoherent. This Article analyzes existing tax provisions of particular relevance to people with disabilities using an ability-to-pay approach to individual income taxation and a human variation paradigm of disability rights, justifying or reframing some provisions and recommending repeal of others. Ultimately, the Article suggests, if the individual income tax system as a whole were to be reframed in terms of individual taxpayers' ability to pay, the mechanical complexity of that system could be rationalized and significantly reduced.

\footnotetext{
${ }^{\dagger}$ Professor, Loyola Law School, Los Angeles. The authors would like to thank Ellen Aprill, David Duff, Rob Kar, Katie Pratt, and Michael Waterstone for their thoughtful and extensive comments on preliminary drafts.

\# Clinical Professor, Loyola Law School, Los Angeles, and former Director, Western Law Center for Disability Rights. This Article is dedicated to Kira Seto, for her patience and support.
} 
INTRODUCTION 1055

I. AN INTRODUCTION TO DISABILITY LAW AND THEORY: STRUGGLING TO FIND A PARADIGM ....................................... 1058

A. The Affliction Paradigm .......................................................... 1058

B. The Medical/Charity Paradigm............................................... 1059

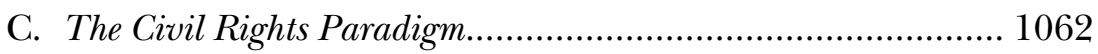

D. Emergence of a Human Variation Paradigm ............................ 1071

II. AN INTRODUCTION TO THE FEDERAL INCOME TAXATION OF INDIVIDUALS: FROM THE THEORETICALLY ELEGANT TO THE

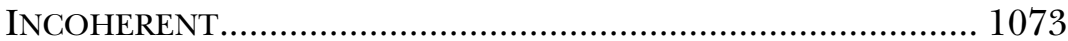

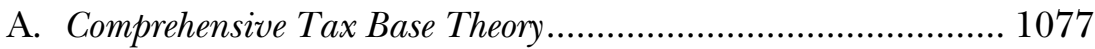

B. Theories of Progressive Taxation .............................................. 1081

C. Mechanical Structure of the Individual Income Tax ................. 1086

D. Reframing the Income Tax, in Part, as a Tax on Ability To Pay 1100

III. TAX PROVISIONS OF PARTICULAR RELEVANCE TO PEOPLE WITH DISABILITIES................................................. 1105

A. Provisions Consistent with the Medical/Charitable Model of Disability.

B. Provisions Consistent with the Civil Rights Model of Disability....

C. Provisions Consistent with the Human Variation Model of Disability.

IV. PROPOSAls FOR CHANGE.

A. First-Best: Proposals for the Retention, Amendment, or Repeal of Tax Provisions of Particular Relevance to People with Disabilities Within the Context of an Ability-to-Pay Income Tax.

B. Second-Best: Proposals for the Retention, Amendment, or Repeal of Tax Provisions of Particular Relevance to People with Disabilities Within the Context of the Current Income Tax..... 


\section{INTRODUCTION}

The Census Bureau estimates that at the end of 1994, approximately 54 million Americans (over $20 \%$ of the U.S. population ${ }^{1}$ ) had some type of disability; 26 million, a severe disability. ${ }^{2}$ Since that time, the U.S. population has both grown and aged $;^{3}$ the number of people with disabilities is therefore probably larger today. ${ }^{4}$ The Internal Revenue Code contains numerous discrete and largely uncoordinated provisions dealing with or of particular relevance to people with disabilities. Yet so far as we have been able to ascertain, no serious academic analysis of the policy issues underlying the U.S. taxation of people with disabilities or of those who interact most closely with them has ever been published. ${ }^{5} \quad$ Disability and tax scholars, each

${ }^{1}$ See U.S. Census Bureau, Intercensal Estimates of the United States Population BY SEX, 1990-2000: SELECTED MONTHS (2002), http://www.census.gov/ popest/archives/EST90INTERCENSAL/US-EST90INT-01.html (estimating that the U.S. resident population on July 1, 1994, was 263,125,821).

2 John M. MCNeil, U.S. Census Bureau, Current Population Reports: AMERICANS WITH DISABILITIES: 1994-95, at 1 (1997), http://www.census.gov/prod/3/ 97pubs/p70-61.pdf.

${ }^{3}$ In 1990, the population of the United States was 249 million and had a median age of 32.9. U.S. Census Bureau, 1990 Census of POPUlation: General POPUlation CHARACTERISTICS: UNITED STATES 19 tbl.14 (1992), http:// www.census.gov/prod/cen1990/cp1/cp-1-1.pdf. By 2003, it had risen to 291 million and had a median age of 35.9. U.S. CENSUS BUREAU, ANNUAL Estimates OF THE Population by SEX AND Five-YeAR Age GROUPS FOR THE United STATES: APRIL 1, 2000 TO JULY 1, 2003, at 1 (2004), http://www.census.gov/popest/national/asrh/ NC-EST2003/NC-EST2003-01.pdf.

${ }^{4}$ The disability rights movement uses the term "people with disabilities" in place of "handicapped people" or "the disabled" because it places the person first and the impairment second. The term "people with disabilities" is used in the Americans with Disabilities Act as well. 42 U.S.C. $§ 12101$ (a) (6) (2000). This Article will follow the same convention.

${ }^{5}$ We have found few publications discussing the portions of the Internal Revenue Code relevant to people with disabilities. The two most extensive are I.R.S. Publication 907: Tax Highlights for Persons with Disabilities (2005), available at http:// www.irs.gov/pub/irs-pdf/p907.pdf, which is purely descriptive; and STEVEN B. Mendelsohn, TAX Options and STRATEgies for PEOPle with Disabilities, at vii (2d ed. 1996), a practitioner's manual intended to provide "information on how the tax system could be used to reduce the economic costs of living productively with a disability." Francine Lipman has written on three specific Code provisions relevant to people with disabilities. See Francine J. Lipman, Enabling Work for People with Disabilities: A Post-Integrationist Revision of Underutilized Tax Incentives, 53 AM. U. L. REV. 393, 402 \& n.40 (2003) (analyzing the architectural and transportation barriers removal deduction of I.R.C. $\S 190$, small business public accommodations credit of I.R.C. $\S 44$, and work opportunity tax credit of I.R.C. $\$ 51$ ). A new disability law treatise briefly describes these same three provisions, together with the welfare-to-work tax credit, and 
largely ignorant of the others' specialties, appear for the most part to have avoided the subject. This is regrettable. Tax rules of particular relevance to people with disabilities are too important for disability specialists to ignore in assessing federal disability policy. Conversely, the problems of people with disabilities raise issues that go to the heart of income tax theory and policy.

When we began writing this Article, our intention was simply to introduce U.S. income tax law and policy to disability specialists and disability law and policy to tax specialists. As we struggled to explain the consequences of the relevant tax provisions, however, we realized that the incoherence of those provisions reflected underlying difficulties both in tax and disability theory and in the mechanical structure of the income tax system as a whole. The final incarnation of this Article, therefore, explores both tax and disability theory and the mechanical structure of the tax system at greater length than our topic might seem to warrant. Such an extended exploration is necessary, however, both to understand the problems involved and to provide support for our policy proposals, the most far-reaching of which involve a fairly radical simplification of the structure of the individual income tax system itself.

Part I offers an overview of disability law and theory. Disability theory has changed markedly over the past century. The early 1900s saw the replacement of an affliction paradigm, in which disability was viewed as a punishment or test imposed by God, with a medical/charity paradigm, in which people with disabilities came to be viewed instead as appropriate objects of pity and philanthropy. The result was the enactment of a wide variety of special programs to help Americans with disabilities. The second half of the twentieth century, in turn, witnessed rejection of this medical/charity paradigm, viewed by the disability rights community as demeaning, in favor of a more militant civil rights model, in which people with disabilities claimed a right to equal treatment. This time, the result was the enactment of extensive disability rights legislation, culminating in the Americans

further discusses the difficulties low-income taxpayers have responding to tax incentives to save. Peter BLANCK ET AL., Disability Civil Rights LAW AND Policy 33-1 to 33-10 (2004); see also Mark C. Weber, Disability and the Law of Welfare: A PostIntegrationist Examination, 2000 U. ILL. L. REV. 889, 923 (focusing primarily on problems in disability rights theory). In his concluding pages, Weber calls for the creation of a tax credit for people with disabilities analogous to the earned income credit. Weber, supra, at 947. Additionally, David Duff has published an excellent analysis of the relevant Canadian tax provisions. David G. Duff, Disability and the Income Tax, 45 MCGILL L.J. 797, 804 (2000). 
with Disabilities Act of 1990. Disability theorists then began to realize that the equality model they were using was inconsistent with many of the assistance programs they had won on the basis of the older medical/charity paradigm-programs still important to Americans with disabilities. Recent years have therefore seen the development of a new "human variation" paradigm that attempts to reconcile the two. This new paradigm asserts that society should be structured affirmatively to take differences into account, with the goal of allowing equal participation by all, despite those differences, to the greatest extent possible.

Part II turns to tax. To understand tax rules of particular relevance to people with disabilities, one must first understand the theoretical and mechanical underpinnings of the system as a whole. That system, it will be seen, is both theoretically and mechanically incoherent in significant ways. The most widely accepted theory of the income tax base, known as comprehensive tax base theory, focuses on the correct measurement of income, often to the exclusion of other goals, and is distinct from and uncoordinated with the most widely accepted theory of graduated tax rates, which holds that the purpose of progressivity is utilitarian redistribution. As a result, standard tax theory largely ignores differences-other than differences in "income"in the ability of taxpayers to pay taxes. This, in turn, seriously limits its capacity to model popular moral intuitions about fair taxation. The mechanical structure of the system, caught between theory and moral intuition, has in turn become profoundly stressed-to the point that today many are ready to scrap the system altogether.

At the end of Part II, we suggest that ability to pay be revived as an analytic tool. We believe that a non-utilitarian ability-to-pay theory fits and justifies significant portions of existing law, offers a coordinated explanation of both base and rates, and is consistent with popular notions of tax fairness. In particular, such a theory explains existing tax provisions of particular relevance to people with disabilities far better than standard tax theory does. It may also permit significant simplification of the conceptual-and therefore also the mechanicalstructure of the individual income tax system as a whole.

Part III then explores specific tax provisions of particular relevance to people with disabilities within this larger theoretical context. Subpart A reviews provisions that had their origin in the medi$\mathrm{cal} /$ charity paradigm rejected by the disability rights community (and apparently by Congress) some thirty or forty years ago as paternalistic and subordinating. We reframe most of those provisions in a manner 
consistent with both the human variation paradigm of disability and a non-utilitarian ability-to-pay theory of individual income taxation. Subpart B explores tax rules grounded in the civil-rights paradigm. Finally, Subpart C explores a series of apparently random and as-yet uncoordinated developments most persuasively explained by reference to the human variation paradigm and ability to pay. Most importantly, we note a recent major expansion in the scope of the medical expense deduction, largely unheralded by tax scholars, consistent with those theories and difficult to explain on any other basis. Part IV then summarizes our proposals for change, both first-best and second-best.

\section{AN INTRODUCTION TO DISABILITY LAW AND THEORY: STRUGGLing TO FIND A PARAdIGM}

Whether existing U.S. income tax provisions of particular relevance to people with disabilities make sense depends on what those provisions are supposed to accomplish. Tax policy regarding people with disabilities should, of course, be consistent with overall federal disability policy. Unfortunately, there is as yet no such coherent policy. A civil rights paradigm has dominated recent congressional action with regard to disability issues. That paradigm, however, does not explain important parts of disability law grounded in an earlier medi$\mathrm{cal} /$ charity view of disability. A new human variation theory, recently proposed by a number of disability scholars, may reconcile the two.

\section{A. The Affliction Paradigm}

Until the late nineteenth or early twentieth century, Americans commonly viewed disability as a punishment or test imposed by God. "God, in His mysterious wisdom, had afflicted someone with this particular burden, and they were supposed to bear it with patience and faith ...." Disabilities were "the external expression of an individual's sinfulness and moral impurity." " Disability was "brought on by sin." ${ }^{8}$ Only one class of people with disabilities was absolved of

\footnotetext{
${ }^{6}$ Cheryl L. Anderson, "Deserving Disabilities": Why the Definition of Disability Under the Americans with Disabilities Act Should Be Revised To Eliminate the Substantial Limitation Requirement, 65 Mo. L. REv. 83, 88 (2000) (quoting Beyond Affliction: The Disability History Project (NPR broadcast May 1998) (transcript on file with the University of Pennsylvania Law Review)).

${ }^{7}$ Paula E. Berg, Ill/legal: Interrogating the Meaning and Function of the Category of Disability Antidiscrimination Law, 18 YALE L. \& POL'Y REV. 1, 5 (1999).

${ }^{8}$ Joseph P. Shapiro, No Pity: People with Disabilities Forging a New Civil RIGHTS MOVEMENT 30 (1993).
} 
blame-veterans disabled in the service of their country. In 1636, Plymouth Colony provided for the support of disabled soldiers. ${ }^{9}$ The Continental Congress did the same. ${ }^{10}$ With the exception of veterans, however, the affliction model justified ostracism and mistreatment of people with disabilities.

Today, the affliction paradigm has been abandoned in most contexts. It retains its strongest normative pull in the analysis of disabilities sometimes attributed to the victim's own blameworthy actions: alcoholism and other addictions, HIV infection, and emotional or learning disabilities that some believe could be overcome if only the victim "tried harder." Federal disability statutes, for the most part, reject the affliction paradigm. ${ }^{11}$ Courts nevertheless sometimes seem influenced by that paradigm in construing those same statutes. ${ }^{12}$

\section{B. The Medical/Charity Paradigm}

Around a century ago, the affliction paradigm gradually gave way to a more compassionate medical/charity paradigm, ${ }^{13}$ which viewed people with disabilities as objects of pity, philanthropy, and paternalistic rehabilitation. In 1918, the Vocational Rehabilitation Act established a federal rehabilitation program for disabled soldiers; in 1920, the Smith-Fess Act was passed for civilians. ${ }^{14}$ In 1934, consistent with this new model, the first Easter Seal pictured a sad boy with leg braces and crutches with the text: "Help Crippled Children." When Social Security was created in 1935, it included a disability insurance com-

\footnotetext{
${ }^{9}$ Veterans Administration, A Brief History of the VA, http://www.va.gov/facmgt/ historic/Brief_VA_History.asp (last visited Mar. 23, 2006).

${ }^{10} I d$.

${ }^{11}$ See Sande L. Buhai, In the Meantime: State Protection of Disability Civil Rights, 37 LOYOLA L.A. L. REV. 1065, 1079 (2004) (describing Congress's application of the civil rights paradigm to people with disabilites).

${ }^{12} I d$. at 1089.

${ }^{13}$ SHAPIRO, supra note 8, at 12.

${ }^{14}$ Chai R. Feldblum, Definition of Disability Under Federal Anti-Discrimination Law: What Happened? Why? And What Can We Do About It?, 21 BERKELEY J. EMP. \& LAB. L. 91, 95-96 (2000). In 1954, Congress passed the Vocational Rehabilitation Amendments, adding physical rehabilitation and certain health care services. Pub. L. No. 565, § 11, 68 Stat. 652, 659-61 (1954).

${ }^{15}$ In 1938, the March of Dimes also adopted a medical/charity mode of disabilityrelated fundraising, portraying children with disabilities as the natural objects of charity. Paul K. Longmore \& David Goldberger, The League of the Physically Handicapped and the Great Depression: A Case Study in the New Disability History, 87 J. AM. HIST. 888, 895-96 (2000).
} 
ponent. ${ }^{16}$ A number of states created welfare programs at about the same time; most included special provisions for people with disabilities. These state programs, for the most part, were subsumed in the federal Supplemental Security Income (SSI) program in the mid1970s. ${ }^{17}$

Today, the Social Security system continues to provide two principal benefits for people with disabilities: Social Security Disability Insurance and SSI. ${ }^{18}$ The disability insurance program is funded by the Social Security tax and is therefore contributory in form. Employer and employee each contribute payroll taxes; once a threshold amount has been contributed, the employee is covered by the program. ${ }^{19}$ If the employee then becomes disabled, she is entitled to benefits based on her contributions and contributions made on her behalf, regardless of need. In 2003, over 6.8 million individuals received this disability benefit; the average amount received was $\$ 10,344$ per year. ${ }^{20}$ SSI, by contrast, is a noncontributory means-tested welfare program. ${ }^{21}$ In 2003 , the federal maximum annual amount was $\$ 6,624$ per individual or $\$ 9,948$ per couple. ${ }^{22}$ The amounts actually paid vary from state to state; states may contribute money over and above the federal amount.

${ }^{16}$ SHAPIRO, supra note 8 , at 62 .

${ }^{17}$ Social Security Amendments of 1972, Pub. L. No. 92-603, 86 Stat. 1329.

${ }^{18}$ See Robert Rich et al., Critical Legal and Policy Issues for People with Disabilities, 6 DePaul J. Health CARE L. 1, 13-14 (2002) (describing these two benefits); Ann Ruben, Note, Social Security Administration Crisis: Non-Acquiescence and Social Insecurity, 52 BROOK. L. REV. 89, 89 n.2 (1986) (same).

${ }^{19} 26$ U.S.C. $\$ 3111$ (a) (2000); 42 U.S.C. $\$ 414$ (2000).

${ }^{20}$ Office of Policy, Soc. Sec. Admin., Annual Statistical Report on the SOCIAL SECURITY DisABILITY InSURANCE PROGRAM, 2003 (2004), http://www.ssa.gov/ policy/docs/statcomps/di_asr/2003/index.html.

${ }^{21}$ To qualify for SSI, an individual may not have assets in excess of $\$ 2,000$, and a couple's assets may not exceed \$3,000. OfFICE OF BENEFICIARY DETERMINATIONS \& Servs., Soc. Sec. Admin., Understanding Supplemental Security Income (SSI) 10 (2005), http://www.ssa.gov/notices/supplemental-security-income/ussi-2005.pdf. There are some assets that are excluded, such as the home the beneficiary lives in, life insurance policies with a face value of less than $\$ 1,500$, most cars, burial plots or burial funds up to $\$ 1,500$, and some items needed in order to work. Id. at 16,39 . As for income, if an individual has income during a month, the first $\$ 20$ from any source is not counted and the first $\$ 65$ from working is not counted. Half of the amount over $\$ 65$ from working is counted. Food stamps and shelter provided by private nonprofits do not count as income. Id. at 19.

${ }^{22}$ Soc. Sec. Admin., Fast Facts and Figures About Social Security 2003, http:// www.ssa.gov/policy/docs/chartbooks/fast_facts/2003/fast_facts03.html (last visited Mar. 23, 2006). 
Over seven million people with disabilities currently receive SSI benefits. $^{23}$

To receive benefits under either program, individuals must meet the Social Security Act's definition of "disability": "inability to engage in any substantial gainful activity by reason of any medically determinable physical or mental impairment which can be expected to result in death or which has lasted or can be expected to last for a continuous period of not less than 12 months." ${ }^{24}$ As is typical for programs based on the medical/charity model, the Social Security Act thus purports to help only people so disabled that they cannot participate in the market economy at all-people perceived as appropriate objects of pity and philanthropy. It ignores those who support themselves, however inadequately, regardless of the difficulty. A claimant must "not only [be] unable to do his previous work," but also be incapable of "engag[ing] in any other kind of substantial gainful work which exists in the national economy," ${ }^{25}$ taking into consideration factors such as age, education, and work experience. The object is not to bring people with disabilities into the mainstream. It is rather to meet our perceived moral obligations towards those less fortunate than ourselves.

A complex burden-shifting procedure is used to determine whether an individual meets the statutory criteria. ${ }^{26}$ A claimant must establish that she is not engaging in any substantial and gainful activity. She must also show that she meets the statutory severity requirement by showing either that she has an impairment the Act deems so severe as to automatically preclude substantial gainful activity or that she is in fact unable to perform her prior occupation. ${ }^{27}$ Once these showings are made, the burden shifts. ${ }^{28}$ Unless the Social Security Administration demonstrates that the claimant is able to perform "substantial gainful work which exists in the national economy," the individual is deemed disabled and entitled to benefits. ${ }^{29}$

In addition to benefits provided through the Social Security program, people with disabilities continue to receive aid under a wide va-

${ }^{23}$ There were 7,153,830 recipients as of January 2006. Soc. Sec. Admin., SSI Monthly Statistics (Jan. 2006), http://www.ssa.gov/policy/docs/statcomps/ssi_monthly/ 2006-01/table01.html.

${ }^{24} 42$ U.S.C. $\$ 423(\mathrm{~d})$ (1) (A) (2000).

${ }^{25} I d . \S 423(\mathrm{~d})(2)(\mathrm{A})$.

${ }^{26}$ See, e.g., Bowen v. Yuckert, 482 U.S. 137, 140-42 (1987) (describing the process for reviewing a claim of disability under the Social Security Act).

${ }^{27} \mathrm{Id}$.

${ }^{28}$ Id. at 146 n.5.

${ }^{29}$ Id. at 140 . 
riety of other programs based on the medical/charity paradigm, both narrowly targeted and widely applicable, administered by federal, state, and local governments. In 1994, the Census Bureau noted that "[a]mong the 13 million people age 22 to 64 who received meanstested cash, food, or rent assistance, 50.6 percent had either a severe or nonsevere disability, and 40.3 percent had a severe disability." "In other words, over half the beneficiaries of America's so-called "safety net" had some kind of disability.

\section{The Civil Rights Paradigm}

Under the medical/charity model, the paraplegic's exclusion from work and social activities was attributed to her disability. Society was free from blame or responsibility so long as it extended pity and charity. The model expected individuals with disabilities to fix themselves, using medicine, rehabilitation, and training. Apart from pity and philanthropy, it asked nothing of society; in particular, it did nothing to challenge society's view of people with disabilities as different and inferior.

The civil rights movements of the 1960s and 1970s stimulated development of a civil rights model that challenged the medical/charity paradigm. This new model asserted that disability, like race, was in significant part a social construct-a series of decisions by society to make disability matter. Under the civil rights model, people with disabilities were not necessarily different from anyone else in any way that ought to matter. Instead, society had constructed a world that made disabilities unnecessarily relevant. The disability was not the barrier; the stairs were the barrier. They had been built as the result of a societal decision to favor stairs over ramps-to favor those who walked over those using wheelchairs. Society, not the 17 million Americans who had difficulties with stairs, ${ }^{31}$ had created the barriers. A significant portion of the problems faced by people with disabilities were thus reframed as the result of societal indifference and discrimi-

\footnotetext{
${ }^{30}$ MCNEIL, supra note 2, at 4.

${ }^{31}$ In 1992, the Census Bureau found that 17.5 million U.S. residents had trouble going up a flight of stairs. Ctrs. for Disease Control and Prevention, Current Trends: Prevalence of Disabilities and Associated Health Conditions-United States, 1991-1992, 43 MORBIDITY \& MORTALITY WKLY. REP. 730, 731 (1994) (citing Census Bureau calculations).
} 
nation, not as the inevitable consequences of the disabilities themselves. $^{32}$

This new civil rights model was supported by evidence of widespread discrimination against people with disabilities. In their treatise on disability law, Bonnie Tucker and Bruce Goldstein describe some of the problems that led to enactment of the Americans with Disabilities Act in 1990:

[A]s late as early 1990 Americans with disabilities continued to suffer discrimination in all walks of life. Indeed, in the late 1980s Americans with disabilities were sometimes prevented from going to movies or other places of entertainment, or from dining in restaurants, because managers or owners of such facilities did not like their looks. One person with a disability recounted a situation in which people attempted to forcibly remove her and a friend with a disability from an auction house because they were "disgusting to look at." Another person with a disability, a victim of cerebral palsy, recounted a 1988 incident in which the owner of a movie theater prohibited her from attending movies at his theater because "I don't have to let her in here, and I don't want her in here." People who use wheelchairs frequently tell of being refused service in restaurants.

Other recent illustrative incidents of discrimination against people with disabilities include: (1) the refusal of a New Jersey private-zoo owner "to admit children with Down Syndrome to the monkey house because, he claimed, they upset his chimpanzees"; (2) the refusal of a bank to allow a man with mental retardation to open a bank account because he did not fit the image the bank wanted to project; (3) the action of "an airline employee in New York who resented having to help a 66-year-old double amputee board a plane [and thus] instead threw him on a baggage dolly"; (4) the refusal of a taxi driver in Washington, D.C., to pick up a woman in a wheelchair; and (5) the action of a police officer in pointing his gun at the head of a person with a disability, cocking it, and "pull[ing] the trigger on an empty barrel because he thought it would be 'funny' since [the individual has] quadrapereses and couldn't flee or fight."

In a series of laws enacted in the latter part of the 20th century, Congress clearly adopted the civil rights paradigm. Modeled after civil rights laws applicable to other groups, the Rehabilitation Act of

32 Jerome E. Bickenbach, Physical Disability ANd Social Policy 13 (1993) (noting that disabilities are "socially constructed phenomena brought about by attitudes toward people with disabilities which, once embedded in social practices and institutions, sustain the disadvantageous social condition of people with disabilities").

${ }^{33}$ BONNIE P. TuCKer \& Bruce A. Goldstein, Legal Rights of PERSONS With DisABILITIES 1:4-1:5 (1991) (footnotes omitted). 
$1973,{ }^{34}$ the Individuals with Disabilities Education Act of $1975,{ }^{35}$ the Fair Housing Amendments Act of 1988, ${ }^{36}$ and the Americans with Disabilities Act of $1990^{37}$ all invoked the new paradigm. Their premise was that people with disabilities were people like anyone else, but faced special barriers that fear, stereotyping, and prejudice had erected against them. Instead of expecting people with disabilities to overcome those barriers themselves, these new acts required society affirmatively to dismantle any unreasonable barriers it had created. The assumption was that once the barriers were removed, people with disabilities would be integrated into the mainstream of American society. $^{38}$ Even the process of getting these acts passed and implemented followed the civil rights model; massive demonstrations forced the issuance of regulations implementing the Rehabilitation Act. $^{39}$

\section{Rehabilitation Act of 1973}

Section 504 of the Rehabilitation Act was enacted to prevent "discrimination, exclusion or denial of benefits to otherwise qualified handicapped individuals by any program or activity receiving Federal financial assistance." ${ }^{40}$ It provided, in pertinent part, that " $[\mathrm{n}] \mathrm{o}$ otherwise qualified individual with a disability ... shall, solely by reason of her or his disability, be excluded from the participation in, be denied the benefits of, or be subjected to discrimination under any program or activity receiving Federal financial assistance." ${ }^{\prime 1}$ Evidencing adoption of the civil rights model, its language was explicitly patterned after the language of section 601 of the Civil Rights Act of 1964, which prohibited discrimination on the basis of race, color, or national origin. $^{42}$

${ }^{34} 29$ U.S.C. $\$ \S 791-794(2000)$.

35 U.S.C. $\$ \S 1400-1409$ (2000).

3642 U.S.C. $\$ \S 3601-3619$ (2000).

${ }^{37}$ Id. $\$ \$ 12101-12213$.

38 Arlene Mayerson, The History of the ADA: A Movement Perspective (1992), http:/ /www.dredf.org/articles/adahist.html.

${ }^{39}$ In 1977, after disability rights activists held sit-ins and demonstrations across the country, including a sit-in of twenty-eight days in San Francisco, the Department of Health, Education and Welfare finally issued the regulations. Id.

${ }^{40}$ S. REP. No. 93-318, at $\$ 504$ (1973), as reprinted in 1973 U.S.C.C.A.N. 2076, 2143.

4129 U.S.C. $\$ 794($ a) $(2000)$.

4242 U.S.C. $\$ 2000 d$ (2000). 
Consistent with the new paradigm, the 1973 Rehabilitation Act took an approach to defining disability very different from that of the 1935 Social Security Act. Instead of limiting its protections to objects of pity and philanthropy, the Act focused on characteristics likely to lead to discrimination. An "individual with a disability" was any person "who (i) has a physical or mental impairment which substantially limits one or more of such person's major life activities; (ii) has a record of such impairment; or (iii) is regarded as having such an impairment." ${ }^{43}$ Similarly, consistent with the new paradigm, the Act was construed to allow wronged individuals a private right of action against their wrongdoers, ${ }^{44}$ granting such individuals the possibility of damages, injunctive relief, and attorney's fees, without any requirement that the plaintiff first exhaust administrative remedies. ${ }^{45}$

\section{Individuals with Disabilities Education Act}

Children with disabilities were excluded from the first American public schools; families were expected to educate their children with disabilities at home. ${ }^{46}$ In 1893, the Massachusetts Supreme Judicial Court upheld the exclusion of a mentally retarded child from the

${ }^{43} 29$ U.S.C. $\$ 705(20)$ (B) (2000).

${ }^{4}$ See, e.g., Cousins v. Sec'y of U.S. Dep't of Transp., 857 F.2d 37, 46 (1st Cir. 1988) (finding that a private right of action exists under Section 504); Doe v. NYU, 666 F.2d 761, 765 (2d Cir. 1981) (same); Strathie v. Dep't of Transp., 716 F.2d 227, 229 (3d Cir. 1983) (same); Davis v. Se. Cmty. Coll., 574 F.2d 1158, 1159 (4th Cir. 1978) (same), rev'd on other grounds, 442 U.S. 397 (1979); Camenisch v. Univ. of Tex., 616 F.2d 127, 132 (5th Cir. 1980) (same), vacated on other grounds, 451 U.S. 390 (1981); Jennings v. Alexander, 715 F.2d 1036, 1040-41 (6th Cir. 1983) (same), rev'd on other grounds sub nom. Alexander v. Choate, 469 U.S. 287 (1985); Lloyd v. Reg'l Transp. Auth., 548 F.2d 1277, 1285 (7th Cir. 1977) (same); Miener v. Missouri, 673 F.2d 969, 973 (8th Cir. 1982) (same); Kling v. County of Los Angeles, 633 F.2d 876, 878 (9th Cir. 1980) (same), rev'd on other grounds, 474 U.S. 936 (1985); Pushkin v. Regents of Univ. of Colo., 658 F.2d 1372, 1376 (10th Cir. 1981) (same); Jones v. Metro. Atlanta Rapid Transit Auth., 681 F.2d 1376, 1377 n.1 (11th Cir. 1982) (same).

${ }^{45}$ See, e.g., TUCKER \& GOLDSTEIN, supra note 33, at 3:3-:11 (describing the right of action available under Section 504); Sande Buhai \& Nina Golden, Adding Insult to Injury: Discriminatory Intent as a Prerequisite to Damages Under the ADA, 52 RUTGERS L. REV. 1121, 1128-30 (2000) (detailing the remedies for violations of Section 504); Mark C. Weber, Disability Discrimination by State and Local Government: The Relationship Between Section 504 of the Rehabilitation Act and Title II of the Americans with Disabilities Act, 36 WM. \& MARY L. REV. 1089, 1104-05 (1995) (same).

${ }^{46}$ Kathryn E. Crossley, Inclusion: A New Addition To Remedy a History of Inadequate Conditions and Terms, 4 WASH. U.J.L. \& POL'Y 239, 241-42 (2000). 
public school system. ${ }^{47}$ In 1919, the Wisconsin Supreme Court followed suit with regard to children suffering from paralysis. ${ }^{48}$ Adoption of a medical/charity model did little to change the situation. Prior to 1975, public education of children with special needs was not legally required. ${ }^{49}$

The civil rights paradigm brought change. In education, the new paradigm was embodied in the Education of the Handicapped Act, now known as the Individuals with Disabilities Education Act (IDEA), enacted in 1975. The IDEA reflected Congress's concern that most children with disabilities "were either totally excluded from schools or [were] sitting idly in regular classrooms awaiting the time when they were old enough to "drop out." ${ }^{50}$ For purposes of the IDEA, disability was defined by reference to conditions that commonly led to educational discrimination or deprivation; the protected class consisted of children "with mental retardation, hearing impairments (including deafness), speech or language impairments, visual impairments (including blindness), serious emotional disturbance, . . . orthopedic impairments, autism, traumatic brain injury, other health impairments, or specific learning disabilities ... who, by reason thereof need[] special education and related services. ${ }^{, 51}$ As a condition of receiving educational financial assistance from the federal government, states were required to assure every child with disabilities a free and appropriate education. $^{52}$ The IDEA did not explicitly authorize actions for damages, but did give aggrieved students and parents the right to judicial review of administrative decisions subject to the Act. Courts are currently split on the issue of whether money damages are available for violations of the IDEA. ${ }^{53}$

${ }^{47}$ Watson v. City of Cambridge, 32 N.E. 864, 864-65 (Mass. 1893) (deferring to the supposedly good-faith determination by a school committee that a mentally retarded child could not benefit from the public school system).

${ }^{48}$ State ex rel. Beattie v. Bd. of Educ., 172 N.W. 153 (Wis. 1919). The child suffered from paralysis of the limbs and of the vocal cords and often drooled as a result. $I d$. at 154. The Wisconsin Supreme Court determined that the boy's interest in receiving a public school education "cannot be insisted upon when [the boy's] presence therein is harmful to the best interests of the school." Id.

${ }^{49}$ Crossley, supra note 46, at 239.

${ }^{50}$ Bd. of Educ. v. Rowley ex rel. Rowley, 458 U.S. 176, 179 (1982) (quoting H.R. REP. NO. 94-332, at 2 (1975)).

${ }_{51} 20$ U.S.C. $\$ 1401(3)$ (A) (2000).

${ }^{52} I d . \S 1412(\mathrm{a})(1)$.

${ }^{53}$ Rebecca L. Bouchard, Note, The Relationship Between the Individuals with Disabilities Education Act and Section 1983: Are Compensatory Damages an Available and Appropriate Remedy?, 25 W. NEW ENG. L. REV. 301, 316-18 (2003). 
As a result, "by the 1970s approximately eight million children in the United States received some form of special education, primarily through separate educational facilities." ${ }^{54}$ Disability advocates then invoked Brown v. Board of Education ${ }^{55}$ to argue for the inclusion of students with disabilities in regular classrooms. ${ }^{56}$ In Brown, the Court had held that racially segregated schools resulted in inherently unequal education and were therefore unconstitutional. ${ }^{57}$ Disability advocates argued that the use of separate facilities to educate students with disabilities was similarly inherently unequal. ${ }^{58}$ In consequence, the IDEA was amended to provide that students with disabilities should be provided educational services in the "least restrictive environment."

\section{Fair Housing Amendments Act}

Originally enacted to combat housing discrimination on the basis of race, color, religion, or national origin, ${ }^{60}$ the Fair Housing Act was extended by the 1988 Fair Housing Amendments Act (FHAA) to prohibit discrimination against people with disabilities as well. ${ }^{61}$ The prohibited evil was "refusal to make reasonable accommodations in rules, policies, practices, or services, when such accommodations may be necessary to afford such person equal opportunity to use and enjoy a dwelling." "62 "Handicap" was defined as it had been in the Rehabilitation Act-which is to say, by reference to characteristics likely to lead

54 Crossley, supra note 46, at 243. Crossley goes on to note:

[a]s special education programs increased, a stigma attached to students placed in special educational settings. Thus, educators conducted various experiments to determine if disabled children could be placed in a regular educational environment. These experiments proved to be relatively successful, sparking a movement toward the inclusion of children with disabilities into general classrooms.

Id. (footnotes omitted)

55347 U.S. 483 (1954).

56 See Crossley, supra note 46, at 243 ("The Supreme Court's decision in Brown v. Board of Education bolstered the movement toward inclusion.").

57347 U.S. at 495.

58 See Crossley, supra note 46, at 244 (noting the use of the analogy by advocates for the inclusion of students with disabilities).

59 U.S.C. $\$ 1412$ (a) (5) (2000).

${ }^{60}$ See 42 U.S.C. $\$ \$ 3604-3606$ (1988) (barring discrimination in sale, rental, financing, and brokerage of housing on basis of race, color, religion, or national origin).

${ }^{61}$ H.R. REP. NO. 100-711, at 18 (1988), as reprinted in 1988 U.S.C.C.A.N. 2173, 2179. Specifically, it sought "to end the unnecessary exclusion of persons with handicaps from the American mainstream.” Id.

${ }^{62} 42$ U.S.C. $\$ 3604$ (f) (3) (B) (2000). 
to discrimination. ${ }^{63}$ Several different enforcement mechanisms were authorized, including a private right of action for damages, injunctive relief, and attorney's fees. ${ }^{64}$

The House Judiciary Committee Report in support of the FHAA confirmed that Congress was thereby invoking the civil rights paradigm. The report rejected the use of stereotypes, prejudice, or speculation about threats to safety as grounds for excluding people with disabilities from residential neighborhoods. ${ }^{65}$ It required further that "reasonable accommodation" be made to permit people with disabilities to live in dwellings of their choice. ${ }^{66}$ And it observed that the concept of "reasonable accommodation" had a long history in regulations and case law dealing with discrimination on the basis of handicap, citing a Supreme Court decision interpreting the Rehabilitation Act, ${ }^{67}$ thus inviting a coordinated interpretation of the two acts.

\section{Americans with Disabilities Act}

Finally, in 1990, Congress enacted the Americans with Disabilities Act (ADA), which required equal opportunity for individuals with disabilities in five major areas: employment, public services, transportation, accommodations, and telecommunications. ${ }^{68}$ Its stated purpose is

(1) to provide a clear and comprehensive national mandate for the elimination of discrimination against individuals with disabilities;

(2) to provide clear, strong, consistent, enforceable standards addressing discrimination against individuals with disabilities;

(3) to ensure that the Federal Government plays a central role in enforcing the standards established in [the ADA] on behalf of individuals with disabilities; and

${ }^{63} 24$ C.F.R. $\$ 8.3$ (2005). The FHAA definition appears in 42 U.S.C. $\$ 3602$ (h) (2000), and includes the same definition found in Section 504 of the Rehabilitation Act, 29 U.S.C. $\$ 705$ (20) (B) (2000).

${ }^{64}$ TUCKER \& GOLDSTEIN, supra note 33, at 12:56-:58.

${ }^{65}$ H.R. REP. NO. 100-711, at 18, as reprinted in 1998 U.S.C.C.A.N. at 2179.

${ }^{66} I d$. at 25, as reprinted in 1998 U.S.C.C.A.N. at 2186.

${ }^{67}$ Id. The House Report cited Southeastern Community College v. Davis, 442 U.S. 397 (1979), and 45 C.F.R. $\$ 84.12$.

${ }^{68} 42$ U.S.C. $\$ \$ 12101-12213$ (2000). Prior to the passage of the ADA, the Rehabilitation Act required federal agencies and federally funded programs to provide reasonable accommodations to persons with disabilities. See Rehabilitation Act of 1973, 29 U.S.C. $\$ 794(a)$ (2000) (calling for the promulgation of regulations to ensure that persons not be denied benefits by virtue of their disabilities); see also RICHARD K. SCOTCH, FROM GOOD WILL TO CIVIL RigHTS 49-59 (1984) (chronicling the history of the antidiscrimination provision of the Rehabilitation Act of 1973). 
(4) to invoke the sweep of congressional authority, including the power to enforce the fourteenth amendment and to regulate commerce, in order to address the major areas of discrimination faced day-to-day by people with disabilities. ${ }^{69}$

Again, the ADA defined the protected class by reference to characteristics likely to lead to discrimination. Like the Rehabilitation Act and the FHAA, it protected any person who had a physical or mental impairment that substantially limited one or more of that person's major life activities, was regarded as having such an impairment, or had a record of such impairment. ${ }^{70}$ Major life activities included "caring for one's self, performing manual tasks, walking, seeing, hearing, speaking, breathing, learning and working." ${ }^{71}$ Unlike the Rehabilitation Act, the ADA explicitly excluded from the definition of disability sexual orientation or disorders, compulsive gambling, kleptomania, pyromania, and "psychoactive substance use disorders resulting from current illegal use of drugs." ${ }^{72}$

Perhaps most importantly, Title I of the ADA prohibited covered employers from discriminating against qualified individuals with disabilities with respect to "job application procedures, the hiring, advancement, or discharge of employees, employee compensation, job training, and other terms, conditions, and privileges of employment," ${ }^{, 3}$ and defined discrimination to include "not making reasonable accommodations to the known physical or mental limitations of an otherwise qualified individual with a disability who is an applicant or employee, unless such [employer] can demonstrate that the accommodation would impose an undue hardship on the operation of the business of such [employer]." ${ }^{74}$ "qualified individual with a disability" was defined as a disabled person "who satisfies the requisite skill, experience, education and other job-related requirements of the employment position . . . and who, with or without reasonable accommodation, can perform the essential functions of such position." ${ }^{75}$ An individual who could perform the essential functions with accom-

\footnotetext{
${ }^{69} 42$ U.S.C. $\S 12101(\mathrm{~b})$.

${ }^{70} I d . \S 12102(2)$.

7128 C.F.R. $\$ 35.104$ (2005).

7242 U.S.C. $\$ 12211$.

${ }^{73}$ Id. $\S 12112(\mathrm{a})$.

${ }^{74}$ Id. § 12112(b) (5) (A).

${ }^{75} 29$ C.F.R. $§ 1630.2(\mathrm{~m})$ (2005).
} 
modations was protected only if the accommodations she needed to perform those functions were "reasonable." ${ }^{76}$

The statute then provided that the powers, remedies, and procedures of Title VII of the Civil Rights Act of 1964 applied to alleged violations of Title I of the $\mathrm{ADA},{ }^{77}$ further tying the ADA to the civil rights paradigm. At the time of the ADA's enactment, only equitable remedies were available under Title VII. A year later, however, by the Civil Rights Act of 1991, Congress authorized compensatory and punitive damages in Title VII cases-and thereby in ADA cases-against employers engaging in unlawful discrimination. ${ }^{78}$

The civil rights model has been vital to the political success of the disability rights movement. ${ }^{79}$ First, the model invokes a generally understood frame of reference through which the nondisabled majority can begin to understand the difficulties people with disabilities face in "seeking to participate fully in society." people with disabilities and forge them into a distinct and vocal political constituency. ${ }^{81}$ Finally, Matthew Diller notes, "it has enabled arguments on behalf of people with disabilities to be cast as claims of right in a way that reinforces rather than threatens fundamental values of our society" — equality, fair play, and meritocracy rather than redistribution and subsidization. ${ }^{83}$ "Over the long run, arguments framed as appeals for equal opportunity have proven far more resilient both in the political process and in the courts than attempts to secure redistribution of resources." ${ }^{, 4}$

${ }^{76} \mathrm{Id}$.

7742 U.S.C. $\$ 12117$ (a) (2000).

${ }^{78} I d . \S 1981 \mathrm{a}(\mathrm{a})(2)$; see also S. 1745, 102d Cong. $§ 102$ (as passed by Senate, Oct. $30,1991)$.

${ }^{79}$ See Matthew Diller, Judicial Backlash, the ADA, and the Civil Rights Model, 21 BERKELEY J. EMP. \& LAB. L. 19, 35-37 (2000) (describing the ways in which the civil rights model has helped to frame and advance the political debate regarding rights for people with disabilities).

${ }^{80} I d$. at $34-35$.

${ }^{81} I d$. at 35 .

${ }^{82} I d$.

${ }^{83}$ In fact, he observes, "Because it was anticipated that civil rights protection would enable people to leave the disability benefits rolls, the ADA was even promoted as a means of decreasing the extent of redistribution in our society." Id. at 36.

${ }^{84} I d$. 


\section{Emergence of a Human Variation Paradigm}

Despite its legislative successes, however, the civil rights model does not fully explain federal disability policy; indeed, it does not even fully explain those laws that most clearly invoke it. The Social Security Act and other "safety net" programs-essential to many people with disabilities-are difficult to reconcile with a simple call for equal treatment. As Bonnie Tucker has noted, there is even a conflict between the civil rights movement's call for strict equality and the ADA's accommodation requirements. ${ }^{85}$ A deaf individual, if treated exactly the same as hearing individuals in a movie theater, classroom, or court proceeding, would effectively be excluded from participation. Mere equal treatment may not result in the integration of people with disabilities into the societal mainstream. ${ }^{86}$

Is equality enough? Today, many in the disability rights movement are moving towards the conclusion that it is not. ${ }^{87}$ Even after the ramps are built, the paraplegic must still buy the wheelchair and the specially modified car. Some people with disabilities will be limited in the work they can do and the income they can earn, no matter how extensive the accommodations. Many will never work. Notwithstanding extensive congressional action, people with disabilities continue to be less well-educated and more likely to be unemployed than those without. ${ }^{88}$ The challenge to the disability rights movement is to formulate a theory that retains the dignity of the civil rights model but acknowledges these special problems.

Several scholars have attempted to articulate such a theory, which Richard Scotch and Kay Schriner label the "human variation" model. Under this emerging paradigm, problems faced by people with disabilities are viewed

as the consequence of ... social institutions ... having been constructed

to deal with a narrower range of variation than is in fact present in any

\footnotetext{
${ }^{85}$ Bonnie Poitras Tucker, The ADA's Revolving Door: Inherent Flaws in the Civil Rights Paradigm, 62 OHIO ST. L.J. 335, 343 (2001).

${ }^{86}$ Id. at 344 .

${ }^{87}$ See, e.g., Samuel R. Bagenstos, The Future of Disability Law, 114 YALE L.J. 1 (2004) (advocating return to something similar to the medical/charity paradigm).

${ }^{88}$ While $82 \%$ of the general population have more than a high school education, only $37 \%$ of people with disabilities fall into that category. Rich, supra note 18 , at 3940. Also, people with disabilities are more than twice as likely to be unemployed as those without disabilities. See Mitchell P. LaPlante et al., Disability and Employment, DisABILITIES STAT. ABSTRACT, Jan. 1996, at 1 (finding an unemployment rate of $13.4 \%$ for labor force participants with work disabilities as compared to $5.6 \%$ for those without).
} 
given population. Thus those individuals whose mobility, communication, medical needs, or cognition differs from social norms find themselves confronting institutions not well suited to their abilities and potential. $^{89}$

Society should reexamine its structures, both physical and social, they urge, to accommodate the full range of human variation. ${ }^{90}$ Harlan Hahn similarly argues that today's world was designed for people who decision makers view as "normal:""1

Features of the human-made environment that segregate disabled citizens from the rest of the population have not been decreed by immutable natural laws, nor were they produced by historical happenstance or coincidence. They represent conscious choices that had the effect of including some groups, such as the dominant segments of society, and excluding others who were "different" or disabled.

He advocates a world adapted to the needs of everyone, not just those of the dominant majority. ${ }^{93}$ Michael Wald notes that the disability rights movement urges "that everybody [be] entitled to an individualized plan that will allow them to fully participate in the economic, political, and social life of their communities." ${ }^{94}$

A human variation paradigm would appear to solve many of the problems of the civil rights approach, while retaining much of its normative power. It justifies both a safety net and accommodation on equality grounds. In effect, it invokes John Rawls' choice from behind the veil of ignorance: ${ }^{95}$ if it were possible that you might be paralyzed from the waist down, how would you like society to be structured?

Care must be taken in how such a model is articulated. Disability is not mere variation. If it were, the following two questions would be normatively equivalent: "Can parents authorize an operation to make their children blind?" and "Can parents authorize an operation to give

${ }^{89}$ Richard K. Scotch \& Kay Schriner, Disability as Human Variation: Implications for Policy, 549 AnNals AM. ACAD. POL. \& SOC. SCI. 148, 155 (1997).

${ }^{90} \mathrm{Id}$.

${ }^{91}$ See Harlan Hahn, Accommodations and the ADA: Unreasonable Bias or Biased Reasoning?, 21 BERKELEY J. EMPL. \& LAB. L. 166, 178 (2000) ("Social structures were designed to enhance the prestige and authority of the non-disabled ....”).

${ }^{92} I d$. at 174 .

${ }^{93}$ Id. at 192 .

${ }^{94}$ Michael S. Wald, Moving Forward, Some Thoughts on Strategies, 21 BERKELEY J. EMPL. \& LAB. L. 473, 473 (2000).

${ }^{95}$ See JOHN RAWLS, A THEORY OF JUSTICE 136-42 (1971) (advocating the adoption of those principles of justice that would be chosen by actors ignorant of their own particular situation and characteristics). 
their children sight?" To most, these questions are quite different. Given the unavoidable existence of disability, however, both equality and fairness support the conclusion that society should be structured to allow participation by all despite their differences, to the greatest extent possible. Our tax policy analysis and conclusions depend heavily on the human variation paradigm we have just articulated.

\section{AN INTRODUCTION TO THE FEDERAL INCOME TAXATION OF INDIVIDUALS: FROM THE THEORETICALLY ELEGANT TO THE INCOHERENT}

Until we began this Article, we had never had occasion to question standard tax theory. Comprehensive tax base theory, commonly used to define the appropriate base for income taxation, has enormous explanatory power. Progressivity we took for granted. As we attempted to apply standard theory to the problems of people with disabilities, however, we discovered that it has almost no capacity to deal with differences-other than differences in income-in taxpayers' abilities to pay taxes. Under comprehensive tax base theory, for example, a quadriplegic taxpayer who earns $\$ 50,000$ but must spend $\$ 20,000$ for a full-time assistant to help her go to the bathroom, wash, dress, and eat is treated as having equal ability to pay taxes as a "normal" taxpayer who earns the same amount but can choose to spend that same $\$ 20,000$ on sky-diving, cello lessons, or long-term investments. We found it implausible that the two should be expected to contribute equally to the functions of government, as comprehensive tax base theory implies.

When we explored further why standard tax theory had so little capacity to deal with differences in ability to pay, we discovered a significant disjunction between the electorate and Congress, on the one hand, and tax theorists, on the other. Congress apparently still believes that " $[0]$ ne of the basic tenets of tax policy is that an accurate measurement of ability to pay taxes is essential to tax fairness." ${ }^{96}$ Conventional wisdom among tax scholars, by contrast, is to the contrary. Over fifty years ago, Walter Blum and Harry Kalven characterized public acceptance of ability to pay in the following terms: "the hold of these notions on the general public must derive from the fallacies that

${ }^{96}$ Staff of J. Comm. On TAXation, 108Th Cong., Description of Revenue Provisions Contained in the President's Fiscal Year 2005 Budget Proposal 8 (Comm. Print 2004). 
have frequented the theories and not from their truths . . .".97 Stephen Utz, in a recent article on the topic, reiterates the view that "no useful formulation of ability to pay has escaped devastating criticism." ${ }^{98}$

This disjunction, we concluded, was an artifact of the dominance of utilitarianism among U.S. tax theorists. Ability to pay was first widely articulated in 1848 by John Stuart Mill. ${ }^{99}$ Over the next hundred years, Mill's successors battled over how best to model ability-topay tax policy, particularly with respect to rate structure, in utilitarian terms. By 1938, economist and tax theorist Henry Simons concluded that all had failed. ${ }^{100}$ Then in 1952, Blum and Kalven published a landmark article expanding on Simon's arguments; ${ }^{101}$ their article was widely accepted by tax scholars as having eliminated any utilitarian implementation of ability to pay as a justification for progressive rates. ${ }^{102}$

One of the problems with the utilitarian approach was that, to be mathematically tractable, it required an assumption that all taxpayers were identical except with respect to income. ${ }^{103}$ In the 1960s, Stanley Surrey incorporated the same then-routine assumption in his definition of a comprehensive tax base. ${ }^{104}$ He summarized his core thesis in the following terms:

The federal income tax system consists really of two parts: one part comprises the structural provisions necessary to implement the income tax on individual and corporate net income; the second part comprises a

${ }^{97}$ Walter J. Blum \& Harry Kalven, Jr., The Uneasy Case for Progressive Taxation, 19 U. CHI. L. REV. 417, 484 (1952).

${ }^{98}$ Stephen Utz, Ability To Pay, 23 WhitTier L. Rev. 867, 870 (2002).

${ }^{99}$ For an excellent review of the history of ability to pay, see $i d$. at 878-939.

${ }^{100}$ See Henry C. Simons, Personal Income Taxation: The Definition of INCOME AS A PROBLEM OF FISCAL POLICY 5-10 (1938) (discussing the problems in earlier theories that advocated progressive taxation).

${ }^{101}$ Blum \& Kalven, supra note 97.

${ }^{102}$ See, e.g., Reuven S. Avi-Yonah, Why Tax the Rich? Efficiency, Equity, and Progressive Taxation, 111 YALE L.J. 1391, 1399 (2002) (book review) (noting that Blum and Kalven "demolish[ed] systematically all previous arguments for progressivity made in the name of 'ability to pay' and 'equal sacrifice'”).

${ }^{103}$ See, e.g., SIMONS, supra note 100, at 10-11 ("[T] he doctrine derives not only all its practical implications but all its noble ethical quality from an assumption usually introduced or recognized without much ceremony. This is the assumption that all individuals are, or must be treated as, equally efficient as pleasure machines [that is, must have identical utility curves].”).

104 Allaire Urban Karzon, Tax Expenditures and Tax Reform, 38 VAND. L. REV. 1397, 1398 (1985) (reviewing Stanley S. SurRey \& PAUl R. MCDANIEL, TAX EXPENDITURES (1985)). 
system of tax expenditures under which Governmental financial assistance programs are carried out through special tax provisions rather than through direct Government expenditures. This second system is grafted on to the structure of the income tax proper; it has no basic relation to that structure and is not necessary to its operation. ${ }^{105}$

The first part of the system-provisions correctly measuring income, not ability to pay in any other regard-defined the ideal income tax base. All other provisions, according to Surrey, should be viewed as the functional equivalent of direct appropriations effected through the tax code. Surrey acknowledged that some of the rate structural features of our system-among them, personal exemptions and the rate schedules-should be viewed as an inherent part of an income tax system based on ability to pay. ${ }^{106}$ Adjustments to base-the medical expense deduction in particular-were to be treated as tax expenditures. ${ }^{107}$ Blum and Kalven having eliminated ability to pay as a justification for rates and Surrey having eliminated it as an independent consideration in defining base, ability to pay effectively disappeared from mainstream U.S. tax theory.

In the meantime, non-utilitarian notions of the relevance of ability to pay retained a strong normative hold on Congress. ${ }^{108}$ As a result,

${ }^{105}$ Stanley S. Surrey, Pathways to Tax Reform: The ConcePt OF TAX EXPENDITURES 6 (1973).

${ }^{106} \mathrm{Id}$. at 16 .

${ }^{107} I d$. at 21-23.

108 See, e.g., H.R. REP. No. 105-148, at 310 (1997) ("The Committee believes that the individual income tax structure does not reduce tax liability by enough to reflect a family's reduced ability to pay taxes as family size increases.”); S. REP. NO. 105-33, at 3 (1997) (same); 2 H.R. ReP. No. 104-280, at 373 (1995) ("The committee believes that the definition of AGI used currently in phasing out the EITC is too narrow and disregards other components of ability-to-pay."); H.R. REP. NO. 104-84, at 10 (1995) ("The Committee believes that the individual income tax structure does not reduce tax liability by enough to reflect a family's reduced ability to pay taxes as family size increases."); H.R. REP. No. 103-111, at 609 (1993) ("[T] he committee believes that extending the EITC to low-income working taxpayers without qualifying children will . . . reduce the burden of the individual income and payroll taxes on those with a lower ability to pay taxes."); $i d$. at 654 ("To limit the effect of this provision to taxpayers with a greater ability to pay taxes, the present-law thresholds are maintained."); H.R. REP. NO. 102-631, at 82 (1992) ("Providing a higher basic EITC credit rate for taxpayers with two or more qualifying children recognizes the equity of providing larger tax benefits to those with a lesser ability to pay taxes."); H.R. REP. No. 101-881, at 361 (1990) (“[T] he committee believes that the goal of personalizing the Federal income tax based on each individual's ability to pay taxes is enhanced by adoption of a rule that imposes some limitation on deductibility of amounts paid ... by high-income individuals, yet generally allows full deductibility at the margin."); 1 S. REP. No. 97-494, at 97 (1982) ("A widely accepted goal of tax policy is that the tax burden be distributed fairly, in accordance with people's ability to pay."); $i d$. at 108 (“[T] he committee has provided an alternative 
our system contains features most easily explained-indeed, sometimes explicitly justified by Congress ${ }^{109}$ - as measuring ability to pay. Theorists often reframe those features as "subsidies" granted for nontax reasons, complaining that such "subsidies" are granted to the wrong taxpayers and distort the Code. ${ }^{110}$ Their concerns are then reflected in complex mechanical structures that limit such "subsidies" in relatively arbitrary ways. The net effect is a system widely perceived to be broken.

In Parts II.A and II.B, we explore the standard scholarly theories of income tax base and rates, theories that do not capture Congress's or the electorate's apparent continuing commitment to ability to pay. In Part II.C, we describe the mechanical structure used to compute tax liability-a structure caught between scholarly theory and intuitive notions of tax fairness that has, as a result, become increasingly inco-

minimum tax which is intended to insure that, when an individual's ability to pay taxes is measured by a broad-based concept of income . . tax liability is at least a minimum percentage of that broad measure."); $i d$. at 115 ("[T] he committee has decided that it is appropriate to put a percentage-of-adjusted-gross-income floor under the casualty loss deduction, ... [ [which] recognizes that the size of a loss that significantly reduces an individual's ability to pay tax varies with his income."); S. REP. NO. 95-1263, at 13 (1978) (" $[\mathrm{I}] \mathrm{t}$ is appropriation [sic] to review the tax system periodically to see whether it is having the appropriate impact on the economy and whether tax burdens are in accordance with taxpayers' ability to pay."); H.R. REP. NO. 95-1445, at 9 (1978) ("[R] elative tax burdens of particular types of taxpayers must be reconsidered in terms of their ability to pay tax and what is a fair distribution among all taxpayers of the total tax burden."); S. REP. NO. 94-938, at 439 (1976) (“[A]djusted gross income . . is a concept that is useful for purposes of computing the appropriate amount of income tax but is not a very good analytical measure of total income for purposes of determining a person's ability to pay income tax."); H.R. REP. No. 91-782 (1969) (Conf. Rep.) (statement of Rep. Wilbur Mills), as reprinted in 1969 U.S.C.C.A.N. 2392, 2464 ("[I]n my opinion taxpayers are interested in improving the tax system because they have reason to believe that there are those who are not carrying their fair share of the tax burden based upon ability to pay."); $i d$. at 2476 (“[W]e have made fundamental changes with the purpose of trying to restore a greater degree of equity under the tax law between taxpayers with the same ability to pay."); H.R. REP. NO. 83-1337, at B7-B9 (1954) (minority views), as reprinted in 1954 U.S.C.C.A.N. 4017, 4600-02 ("This proposal reverses the ability-to-pay principle of taxation .... Adoption of this proposal would mean that those best able to pay their fair share of taxes would be given special treatment resulting in the shifting of the burden of taxation to those least able to bear it."); see also sources cited infra notes 109, 119.

${ }^{109}$ See infra note 119; see also S. REP. NO. 88-830 (1964), as reprinted in 1964 U.S.C.C.A.N. 1673, 1730 ("This means that . . casualty and theft losses will continue to be deductible (over the $\$ 100$ ) in those cases where they are sufficient in size to have a significant effect upon an individual's ability to pay Federal income taxes.").

${ }^{110}$ See, e.g., James W. Colliton, The Medical Expense Deduction, 34 WAYNE L. REV. 1307, 1371 (1988) (arguing that Congress should repeal the medical expense deduction and replace it with a direct reimbursement or insurance plan or with a tax credit). 
herent. In Part II.D, we suggest that reframing the existing U.S. individual income tax system so as to take into account intuitive notions of ability to pay would both make it more comprehensible and allow significant simplification and rationalization of its mechanical structure. Finally, in Part III, we use an ability-to-pay framework to analyze tax rules of particular relevance to people with disabilities. Thus reframed, both the system and the specific rules on which we focus can actually be made to make sense.

\section{A. Comprehensive Tax Base Theory}

At the core of the U.S. income tax system is a single elegant premise: income includes any value received unless that value is paid for with dollars that have already been taxed. Thus, for example, if you receive a car and do not pay for it, you have income. If you receive a car and pay for it by working for a month, you still have income because you have not yet been taxed on your labor. But if you receive a car and pay for it with the already-taxed cash you received for your month's labor, you do not have income, because you are paying for the car with already-taxed dollars.

Economist Henry Simons proposed a somewhat expanded version of this premise. ${ }^{111}$ Your income, he said, equals your change in net worth plus the value of the consumption benefits you receive-like spaghetti to eat, jeans to wear, or an apartment in which to live. Therefore, he concluded:

Income $=$ change in net worth + consumption .

This expanded version, known as the "Haig-Simons definition of income," can be used to explain many basic features of the U.S. income tax system.

Deductibility of the costs of producing income: Assume first that you spend $\$ 1,000$ on costs of producing future income. As a result, your net worth goes down by the $\$ 1,000$ spent. Costs incurred to produce future income do not, in and of themselves, have any further effect. The hoped-for income has not necessarily yet been received. If and when it is, it will be taxed as income. And expenditures to produce future income are not treated as resulting in personal consumption benefits. Your consumption is therefore zero, and your income from the transaction is a $\$ 1,000$ loss (a $\$ 1,000$ decline in net worth $+\$ 0$

111 SIMONS, supra note 100 , at 50. 
consumption). To reflect that loss on your tax return, it follows that the tax system should allow you a $\$ 1,000$ deduction, reflecting the costs of producing income. And in general it does. ${ }^{112}$

Nondeductibility of consumption expenditures: Second, assume instead that you spend $\$ 1,000$ on a Häagen-Dazs ice cream orgy-pure consumption. Now your net worth goes down by $\$ 1,000$, but you also have $\$ 1,000$ of consumption value. Your Haig-Simons income is therefore zero (a $\$ 1,000$ decline in net worth offset by $\$ 1,000$ of consumption). It follows that the tax system should not allow deduction of personal expenses. And in general it does not. ${ }^{113}$

Nondeductibility of capital expenditures: Third, assume that you spend $\$ 1,000$ to purchase a business asset that will retain value for longer than one taxable year-say, a used car you plan to use to carry your plumbing tools from job to job. Now the purchase does not change your net worth at all-or at least not by the full amount of the purchase price. You started with $\$ 1,000$ in cash; immediately after the purchase you have a car worth approximately $\$ 1,000$. You also have no consumption, since you plan to use the car for the production of income. Your net income is again zero. It follows that the tax system should not allow any deduction for capital expenditures (expenditures with useful lives that extend significantly beyond the end of the taxable year) even if they are to be used exclusively for the production of income. And in general it does not. ${ }^{114}$

Depreciation: Over the useful life of that car, however, its value will decline; for simplicity's sake, assume that it declines to zero. Thus over the useful life of the car, your net worth again declines by $\$ 1,000$. It follows that the tax system should allow a deduction for the use of capital expenditures for business purposes over their useful lives. And in general it does; we call that deduction "depreciation" in the case of tangible assets, ${ }^{15}$ "amortization" in the case of intangible assets, ${ }^{116}$ or "depletion" in the case of mineral deposits. ${ }^{117}$

${ }^{112}$ See I.R.C. $\$ \S 162,212$ (2000) (allowing deduction for business expenses and expenses related to the production of income).

${ }_{113}^{11}$ See id. $\$ 262$ (disallowing deductions for personal, living, and family expenses).

${ }_{115}$ See id. $\$ 263$ (disallowing deduction for capital expenditures).

${ }^{115}$ See id. $\$ \$ 167-168$ (allowing deduction for depreciation of income-producing properties and providing a system to determine the amount of deduction for tangible assets).

${ }^{116}$ See id. $\$ \S 167,197$ (providing a system to determine the amount of deductions for depreciation of intangible assets).

${ }^{117}$ See id. $\S 611$ (allowing deduction for depletion of natural deposits). 
Denial of depreciation for personal assets: Finally, assume that you buy the same car for personal purposes. Again, your net worth does not change by reason of the purchase. Over the useful life of the car, however, two things happen: first, the car declines in value by $\$ 1,000$; second, you receive consumption benefits from its use. The tax system treats the decline in value as the measure of the consumption benefits you derive: you experience a $\$ 1,000$ decline in net worth exactly offset by $\$ 1,000$ of consumption value. Your net income over the useful life of the car is therefore zero. It follows that the tax system should not allow depreciation of personal assets. And it does not. ${ }^{118}$

The part of our economy that would ideally be taxed under the foregoing theory is sometimes known as the "comprehensive tax base." Comprehensive tax base theory tells us a lot about what must be includible or deductible if Congress's purpose is to tax "income." Applied in the myriad contexts in which taxpayers make, lose, or recover money or other value, this theory commonly tells us what the rule "must" be, even if no statute or regulation has yet addressed the issue. Some existing deductions and exclusions are justified by comprehensive tax base theory; for want of a better term, this Article refers to them as "income-measuring" deductions and exclusions. No further explanations of such deductions or exclusions are normally thought to be necessary. Others are not so justified; this Article refers to them as "non-income-measuring." Tax theorists commonly follow Surrey's practice of justifying or criticizing these latter deductions or exclusions by reference to values outside the tax system.

For example, medical expenses are generally treated as consumption; their deduction is therefore not thought to be justified by comprehensive tax base theory. ${ }^{119}$ Under comprehensive tax base theory,

${ }^{118}$ See id. $\$ 167$ (a) (limiting deductions for depreciation to assets used in trade or business or held for the production of income).

119 See, e.g., StafF OF J. COMm. On TAXATION, 99TH CONG., GENERAl ExPlanation OF THE TAX REFORM ACT OF 1986, at 50 (Comm. Print 1987) ("[M] edical expenses essentially are personal expenses and thus, like food, clothing, and other expenditures of living and other consumption expenditures, generally should not be deductible in measuring taxable income."); cf. 2 H.R. REP. NO. 98-432, at 1583 (1984), as reprinted in 1984 U.S.C.C.A.N. 697, 1209 ("The primary rationale for allowing an itemized deduction for medical expenses is that extraordinary medical costs reflect an economic hardship, beyond the taxpayer's control, which reduces the taxpayer's ability to pay Federal income tax."); 1 S. REP. NO. 97-494, at 113 (1982) (same); id. at 419 (additional views of Sen. Robert Dole) ("Some of us would have preferred to make a more moderate adjustment in the deductions for medical expenses. ... [While the modification would simplify tax and lower rates,] we do not want to disregard the long-held principle that tax burdens should bear a relation to the taxpayer's ability to pay."); H.R. REP. NO. 95- 
the $\S 213$ deduction for medical expenses, discussed in greater detail below, is instead generally treated as the result of a congressional decision to subsidize such expenses. ${ }^{120}$ Many exclusions, credits, and deductions relevant to people with disabilities are similarly treated as deviations from tax theory, justified primarily on the nontax ground that such people are the appropriate objects of solicitude-in other words, by reference to the medical/charity paradigm of disability. ${ }^{121}$

The widespread acceptance of comprehensive tax base theory is evidenced by continued inclusion in the annual budget of the U.S. Government of a "tax expenditure budget," first instituted by Surrey when he was Assistant Secretary of the Treasury for Tax Policy in $1968,{ }^{122}$ that estimates the budget-equivalent cost of major authorized deviations from the comprehensive tax base. In fiscal 2005, for example, the deduction for medical expenses was estimated to have been equivalent to a direct subsidy of $\$ 8.59$ billion. ${ }^{123}$

1445, at 43 (1978) ("The primary rationale for allowing an itemized deduction for medical expenses is that 'extraordinary' medical costs- those over a floor designed to exclude predictable, recurring expenses-reflect an economic hardship, beyond the individual's control, which reduces the ability to pay Federal income tax.").

${ }^{120}$ See, e.g., SURREY, supra note 105, at 21-23 (discussing the view that the medical expenses deduction is a means of government financial assistance for medical care and arguing that such expenditures are best handled outside the tax code); William J. Turnier, Personal Deductions and Tax Reform: The High Road and the Low Road, 31 VILL. L. REV. 1703, 1730 (1986) ("Medical expenses reflect expenditures to finance consumption of goods and services by the taxpayer to attain a personal benefit ...."). Not all tax scholars agree. See, e.g., William D. Andrews, Personal Deductions in an Ideal Income Tax, 86 HARV. L. REV. 309, 331-43 (1972) (arguing that medical expenses should not be viewed as consumption); $c f$. Mark G. Kelman, Personal Deductions Revisited: Why They Fit Poorly in an "Ideal" Income Tax and Why They Fit Worse in a Far from Ideal World, 31 STAN. L. REV. 831, 880-83 (1979) (contending that the medical expense deduction undermines the redistributive role of the income tax system). A review of the AndrewsKelman debate appears in Jeffrey H. Kahn, Personal Deductions-A Tax "Ideal" or Just Another "Deal"?, 2002 MICH. ST. L. REV. 1, 25-36. While we have some sympathy with Kelman's concerns, we believe that he does not deal adequately with the problem of true individual difference. Our conclusions are therefore closer to those of Andrews. Andrews, however, attempted to fit his argument within a Surrey-style definition of the income tax base, opening himself to Kelman's criticisms.

${ }^{121}$ See supra Part I.B.

122 See Karzon, supra note 104, at 1398-99 (describing Surrey's introduction of the concept of tax expenditures).

${ }^{123}$ OfFice of Mgmt. \& Budget, Budget of the United States Government: ANALYTICAL PERSPECTIVES FisCAL YeAR 2006, at 318 tbl.19-1 (2005). 


\section{B. Theories of Progressive Taxation}

To income, however defined, the U.S. income tax system then applies graduated marginal rates-that is, rates that increase as income increases. In 2005 , the first $\$ 7,300$ of a single individual's "taxable income"-a term of art discussed more fully below ${ }^{124}$-was subject to regular income tax at a rate of $10 \%$, the next $\$ 22,400$ at a rate of $15 \%$, the next $\$ 42,250$ at a rate of $25 \%$, the next $\$ 78,200$ at a rate of $28 \%$, the next $\$ 176,300$ at a rate of $33 \%$, and all remaining income at a rate of $35 \%{ }^{125}$

Technically, under current law, there is no zero-rate bracket-that is, no initial portion of taxable income exempt from tax. Most taxpayers, however, are entitled to a "standard deduction," ${ }^{126}$ which between 1977 and 1986 was actually known as the "zero bracket amount." ${ }^{127}$ One of the effects of the standard deduction is to ensure that some initial portion of most taxpayers' "adjusted gross income" (as opposed to "taxable income") is completely exempt from federal income tax. For 2005, the basic standard deduction for single individuals was $\$ 5,000{ }^{128}$ In addition, most individual taxpayers are entitled to a personal exemption ( $\$ 3,200$ for 2005). ${ }^{129}$ Thus, the 2005 effective rate structure applied to the gross income of most single individuals looked more realistically like this: ${ }^{130}$

124 See infra Part II.C.

${ }^{125}$ Rev. Proc. 2004-71 § 3.01, 2004-50 I.R.B. 970, 972 tbl.3.

${ }^{126}$ I.R.C. $\S 63(\mathrm{c})(2000)$. The standard deduction is not available at all to a taxpayer who elects to itemize her deductions, $i d$. $\S 63(\mathrm{a})-(\mathrm{b})$, a married individual filing separately if his or her spouse itemizes, a nonresident alien individual, or an individual making a return for a period of less than twelve months on account of a change in his or her accounting period, $i d$. $\S 63$ (c) (6). In addition, the standard deduction is limited to a mere $\$ 500$, adjusted for inflation, in the case of taxpayers who are themselves dependents of others. Id. §63(c) (5).

127 See, e.g., Allan J. Samansky, Nonstandard Thoughts About the Standard Deduction, 1991 UTAH L. REV. 531, 536-38 (1991) (recounting the history of the standard deduction and the zero-bracket amount).

${ }^{128}$ Rev. Proc. 2004-71 § 3.10, 2004-50 I.R.B. at 973.

129 I.R.C. $\$ 151$ (2000); Rev. Proc. 2004-71 § 3.17, 2004-50 I.R.B. at 974.

${ }^{130}$ For this purpose, we ignore the effects of the earned income tax credit. See I.R.C. $\$ 32$ (2000) (laying out the structure of the earned income tax credit). 


$\begin{array}{llr}\text { Bracket 1 } & \text { First } \$ 8,200 & 0 \% \\ \text { Bracket 2 } & \text { Next } \$ 7,300 & 10 \% \\ \text { Bracket 3 } & \text { Next } \$ 22,400 & 15 \% \\ \text { Bracket 4 } & \text { Next } \$ 42,250 & 25 \% \\ \text { Bracket 5 } & \text { Next } \$ 78,200 & 28 \% \\ \text { Bracket 6 } & \text { Next } \$ 176,300 & 33 \% \\ \text { Bracket 7 } & \text { Income over } \$ 326,450 & 35 \%\end{array}$

Comprehensive tax base theory does not itself justify progressive taxation. What does? Here, standard U.S. tax theory and popular sentiment diverge. The most widely accepted popular justification for graduated rates remains differences in ability to pay, focusing on the sacrifice taxpayers make in giving up a portion of their earnings to fund the operations of government. ${ }^{131}$ Taxpayers with little income

131 See Michael J. Graetz \& Ian Shapiro, Death by a Thousand Cuts: The Fight OVER TAXING INHERITED WEALTH 267 (2005) ("[F]rom the passage of the Sixteenth Amendment in 1913 until very late in the twentieth century, the idea of progressive taxation based on ability to pay seemed as stable and fundamental to American policy as "no taxation without representation."). A random search of the web suggests continuing non-scholarly consensus on this issue. See, e.g., HENRY GEORGE INSTITUTE, TAXES: WHAT ARE THEY GOOD FOR?, http://www.henrygeorge.org/pdfs/ canons.pdf (last visited Mar. 23, 2006) ("The conventional standard of tax fairness is 'ability to pay.' People with higher incomes are able to pay a greater part of the tax burden. The progressive income tax, for example, is based on ability to pay ...."); InterVarsity Christian Fellowship, Complete Book of Everyday Christianity, http://www.ivmdl.org/cbec.cfm?study=12 (last visited Mar. 23, 2006) ("Tax fairness encompasses the nature of what is taxed,... overall levels of taxes, the individual's ability to pay, the question of exempting some from paying for reasons other than ability to pay... and the relative amounts of the tax burden we share with our neighbors."); MSN Money, Ability to Pay Glossary Definition: Taxes, http://moneycentral.msn.com/ taxes/glossary/glossary.asp?TermID=1 (last visited Mar. 23, 2006) ("Ability to Pay: A principle of taxation. Individuals who earn more income pay more tax . . . because taxpayers who earn more have the ability to pay more. The progressive tax, or higher tax rates for people with higher incomes, is based on this principle."); see also H.R. REP. No. 103-111, at 635 (1993) ("[T] he committee believes that a higher marginal tax rate should be imposed on taxpayers with a greater ability to pay taxes."); S. REP. NO. 91552, at 311 (1969) (individual views of Sen. Albert Gore, Sr.) ("In evaluating the provision of the bill . . . an overriding standard must be applied. This standard is embodied in the Cordell Hull principle of progressivity - taxation based on ability to pay-that was at the heart of the successful move to adopt a Federal income tax as a national policy."); S. REP. NO. 82-781, at 7 (1951), as reprinted in 1951 U.S.C.C.A.N. 1969, 1975 ("Your committee believes that in bracket areas where the progression is already quite steep the formula used in imposing additional taxes should measure ability to pay by taking into consideration taxes already paid."). The ability-to-pay concept itself has a venerable heritage:

[Jesus] looked up and saw rich people putting their gifts into the treasury; he also saw a poor widow put in two small copper coins. He said, "Truly I tell 
generally need it to pay for essentials, such as food, clothing, and shelter. Giving up a significant part of these essentials would be a major sacrifice. We therefore keep tax rates very low at lower income levels or do not tax such income at all. By contrast, depriving a wealthy taxpayer of a fifth luxury car, third vacation home, or fiftieth pair of shoes imposes a relatively small objective sacrifice on that taxpayer, regardless of how passionately he desires that fiftieth pair of shoes. Assuming that government needs a given amount of funding, taking income the wealthy taxpayer would have used to buy a fifth luxury car is thought to be fairer than taking income that less wealthy taxpayers would have used to buy food, clothing, or shelter.

At the very least, ability to pay explains why some initial amount of each taxpayer's income-what Blum and Kalven called an "exemption keyed to at least a minimum subsistence standard of living" ${ }^{132}$ - is almost never subject to income tax. ${ }^{133}$ Blum and Kalven believed there was near unanimous agreement on the appropriateness of such an exemption. ${ }^{134}$ Such agreement appears to persist to this day; despite occasional controversy about graduated rates on income above this initial amount, there appears to be widespread consensus that, in the absence of national emergency, some initial portion of every taxpayer's income should not be subject to income tax. ${ }^{135}$ Nearly every so-called "flat tax" that has been seriously considered by Congress has provided for such an exemption. ${ }^{136}$

Contemporary U.S. tax theorists, however, commonly reject ability to pay as a justification for progressive taxation of income in excess of

you, this poor widow has put in more than all of them; for all of them have contributed out of their abundance, but she out of her poverty has put in all she had to live on."

Luke 21:1-4 (New Revised Standard Version).

${ }^{132}$ Blum \& Kalven, supra note 97 , at 420.

133 See, e.g., S. REP. NO. 91-552, at 343 (1969) ("Ability to pay does not commence until a point is reached in the income scale where the minimum means of life have been obtained." (quoting Introduction to DIV. OF TAX RESEARCH, U.S. DEP'T OF THE TREASURY, INDIVIDUAL INCOME TAX EXEMPTIONS (1947))).

${ }^{134}$ Blum \& Kalven, supra note 97 , at 420.

135 See Nancy C. Staudt, The Hidden Costs of the Progressivity Debate, 50 VAND. L. REV. 919, 921-22 (1997) (noting the consensus among scholars on both sides of the progressivity debate and citing examples).

${ }^{136}$ See, e.g., M. Scotland Morris, Note, Reframing the Flat Tax Debate: Three Not-SoEasy Steps for Evaluating Radical Tax Reform Proposals, 48 FLA. L. REV. 159, 166-72 (1996) (analyzing leading flat tax proposals and noting the presence of an exemption in each of them save one). 
this initial exempt amount. ${ }^{137}$ Graduated marginal rates on such additional income are best justified, they argue, as part of a larger governmental project to maximize social welfare by redistributing income from the wealthy to the poor. The U.S. academic shift to a redistributive rationale is often attributed to Blum and Kalven's 1952 article, which focused on the two then-most current utilitarian implementations of ability to pay: "equal sacrifice" and "proportionate sacrifice." ${ }^{138}$ These implementations, Blum and Kalven observed, justified progressive taxation only if individual utility functions met specified criteria. ${ }^{139}$ Since utility functions were (and remain) unascertainable, it was impossible to demonstrate that either implementation necessarily supported any particular set of progressive rates. ${ }^{140}$ Having called these two implementations into question, they rejected ability to pay

${ }^{137}$ Joel Slemrod's discussion of progressive taxes in the online Concise Encyclopedia of Economics reviews what he calls the "benefit principle," the "ability-to-pay principle," and the "utilitarian principle," and concludes: "The modern theory of optimal income tax progressivity begins with the utilitarian principle, but views the issue as a trade-off between the social benefits of a more equal distribution of after-tax income and the economic damage imposed by highly progressive taxes." Joel B. Slemrod, Progressive Taxes, in The Concise Encyclopedia of Economics, http://www.econlib.org/ library/Enc/ProgressiveTaxes.html (last visited Mar. 23, 2006).

${ }^{138}$ Blum \& Kalven, supra note 97, at 457. According to Blum and Kalven, "equal sacrifice" means "that the quantity of sacrifice, that is, the loss of units of utility, demanded of each individual [must] be equal"; "proportionate sacrifice" means "that each should be required to give up an equal percentage of his total utility derived from money." Id.

${ }^{139} I d$. at 458-59. With regard to equal sacrifice, they stated:

$[\mathrm{I}] \mathrm{n}$ order for equal sacrifice to result in a proportionate tax the utility curve for money must be such that for any given percentage increase in the amount of money there must be a like percentage decrease in the marginal utility of that money.... [W]e shall refer to such a curve as a rectangular hyperbola.... [T] o get progression from the equal sacrifice standard requires not only that the utility of money does decline but that it declines more rapidly than a rectangular hyperbola.

$I d$. With regard to proportionate sacrifice, they stated:

[The Dutch economist Cohen-Stuart] demonstrated that it is possible to construct utility curves which declined in such a fashion that, on some parts of the curves, a regressive tax followed from application of the proportionate sacrifice standard. While it seems that proportionate sacrifice would result in progression under most curves that could be postulated, any argument for progression based on that standard loses some of its force because of the fact that a declining curve does not always result in progression.

Id. at 459 (footnotes omitted).

${ }^{140} I d$. at 462 . For a concise modern restatement of the same argument, see Slemrod, supra note 137. 
altogether, concluding that progressive taxation was more persuasively justified on redistributive grounds. ${ }^{141}$

In a recent review of the literature, Reuven Avi-Yonah asserts that "Blum and Kalven's skepticism about graduated rates remained the standard view among legal theorists until 1987." ${ }^{142}$ In that year, Joseph Bankman and Thomas Griffith applied James Mirrlees' optimal tax theory, ${ }^{143}$ which assumed that "the ultimate goal [of a tax system] is to maximize the sum of the utilities of individuals with identical preferences, ${ }^{144}$ to reanalyze the problem. ${ }^{145}$ Although their article was framed as a defense of redistributive taxation, Bankman and Griffith actually proposed a regressive marginal rate structure-a rate structure in which the tax on each additional dollar would decline at higher incomes. ${ }^{146}$ Since then, others have challenged both Bankman and Griffith's technical assumptions ${ }^{147}$-inconclusively, in Avi-Yonah's view $^{148}$ - and Blum and Kalven's original critique, ${ }^{149}$ almost always within a utilitarian moral universe.

The result of these theoretical developments is that mainstream U.S. tax theorists now justify progressivity with a theory (utilitarian redistribution) that is both (1) distinct from and uncoordinated with the theory they use to define the income tax base (comprehensive tax base theory) and (2) inconsistent with public and congressional intui-

${ }^{141}$ Blum \& Kalven, supra note 97 , at 486-501.

${ }^{142}$ Avi-Yonah, supra note 102, at 1399.

${ }^{143}$ See J.A. Mirrlees, An Exploration in the Theory of Optimum Income Taxation, 38 REV. ECON. STUD. 175, 207-08 (1971) (examining social variables affecting the optimum income tax schedule).

${ }^{144}$ Avi-Yonah, supra note 102, at 1400.

${ }^{145}$ Joseph Bankman \& Thomas Griffith, Social Welfare and the Rate Structure: A New Look at Progressive Taxation, 75 CAL. L. REV. 1905 (1987).

${ }^{146} I d$. at $1955-58$.

${ }^{147}$ See, e.g., Martin J. McMahon, Jr. \& Alice G. Abreu, Winner-Take-All Markets: Easing the Case for Progressive Taxation, 4 FLA. TAX REv. 1, 33-34 (1998) (noting that modern welfare economics rejects Bankman and Griffith's assertion that money has diminishing marginal utility, but accepting the concept themselves); Lawrence Zelenak \& Kemper Moreland, Can the Graduated Income Tax Survive Optimal Tax Analysis?, 53 TAX L. REV. 51, 56 (1999) (arguing that Bankman and Griffith's model is flawed because it focuses on "average rate progressivity, rather than marginal rate progressivity").

148 Avi-Yonah, supra note 102, at 1401-02.

${ }^{149}$ McMahon \& Abreu, supra note 147, at 32-39. Excellent reviews of the literature on progressivity can be found in Avi-Yonah, supra note 102, and in Michael A. Livingston, Blum and Kalven at 50: Progressive Taxation, "Globalization," and the New Millennium, 4 FLA. TAX REV. 731 (2000). 
tions about tax fairness. ${ }^{150}$ This means there is no consensus theory of the U.S. income tax as a whole-a rather astonishing fact, given how long the income tax has been around. It also means that mainstream tax theorists are poorly positioned to explain, refine, or guide congressional action.

The structure of standard tax theory also explains why tax lacks a well-developed theory of individual difference. In standard tax theory, difference is dealt with almost exclusively in the rate structure, which applies differentially to individuals with different incomes, but equally to individuals with equal incomes. Let us return to the quadriplegic taxpayer we postulated in the introduction to this Part. She makes $\$ 50,000$, but because of her disability must spend $\$ 20,000$ more than "normal" taxpayers to deal with the basic tasks of everyday living. Under standard tax theory, the extra $\$ 20,000$ she must spend for help with hygiene, dressing, eating, and other basic tasks is treated as consumption-normatively indistinguishable from a Häagen-Dazs ice cream orgy. According to standard tax theory, she is identical in all material respects to any other taxpayer earning $\$ 50,000$ per year; she has merely made different consumption choices. All such taxpayers have identical incomes; there is no reason to redistribute anything from one to the other; each should therefore contribute equally to the functions of government. ${ }^{151}$

\section{Mechanical Structure of the Individual Income Tax}

Fifty years of tension between academic theory and popular intuitions about tax fairness have placed severe strains on the mechanical structure through which individual income tax liabilities are actually computed. The result is a system on the brink of collapse.

\footnotetext{
${ }^{150}$ In a recent paper reporting continued U.S. public support for progressive taxation, Edward McCaffery and Jonathan Baron find that their survey subjects tend to assess the fairness of taxation separately from the uses to which the resulting funds are put-an approach inconsistent with a redistributive rationale. Edward J. McCaffery \& Jonathan Baron, The Political Psychology of Redistribution, 52 UCLA L. REV. 1745, 1770-72 (2005). The authors explain this by suggesting, in effect, that their subjects are not thinking rationally about the problem: "What can explain the results is the disaggregation bias or isolation effect. ... [S] ubjects looked only (or primarily) at the tax system when adjusting the tax system. They did not adequately factor in the effect of public spending cuts ...." Id. at 1772 .

${ }^{151}$ See, e.g., Beverly I. Moran, Stargazing: The Alternative Minimum Tax for Individuals and Future Tax Reform, 69 OR. L. REV. 223, 223 (1990) ("At the very least, fairness requires that those with equivalent economic incomes pay the same amount of tax." (citing SURREY, supra note 105, at 5)).
} 
The computational process begins with "gross income"-that is to say, theoretical income less so-called "exclusions." Exclusions are receipts excluded from gross income by tax base theory, statute, or administrative action. For example, recoveries of capital (when we get back what we have put into an investment) are excluded because they are not income as a matter of comprehensive tax base theory; the system must allow the exclusion if it is to measure income correctly. Interest on tax-exempt bonds, by contrast, is income in theory, but is excluded by $\S 103$ for reasons external to the tax system. ${ }^{152}$ Similarly, as we discuss further below, payments received in cash or in kind by individuals with disabilities under governmental social benefit programs for the promotion of the general welfare-welfare, SSI, and the likeare theoretically income, but are excluded for nontax policy reasons (at least according to conventional tax theory). ${ }^{153}$ For readers whose principal contact with the income tax system has been their own Form 1040 s, it is important to keep in mind that these exclusions occur before the reporting process ever begins. Theoretical income itself never appears in the computation. Exclusions are not actually subtracted. Instead, taxpayers are asked to begin by reporting the result: "gross income."

From gross income, the system then allows subtraction of what are sometimes called "\$ 62 deductions," "non-itemized deductions," or more popularly, "above-the-line deductions." The result is "adjusted gross income," which is reported on the last line of the front page of the Form 1040. Next, taxpayers are asked to make an election: they may either (1) claim their remaining deductions, sometimes known as "itemized deductions" or more popularly, "below-the-line deductions," on Schedule A or, alternatively, (2) claim a "standard deduction"-in $2005, \$ 5,000$ for a single individual or $\$ 10,000$ for a married couple filing jointly. ${ }^{154}$ Regardless of which they elect, they are also generally allowed to subtract one "personal exemption" (in 2005, \$3,200) for each member of their household. ${ }^{155}$ The result is "taxable income," to which the system applies the graduated rate schedules of $\S 1$ to com-

${ }^{152}$ See I.R.C. $\$ 103$ (2000) (excluding interest on most state and local bonds from calculations of gross income).

${ }^{153}$ See infra Part III.A.1.

${ }^{154}$ See I.R.C. $\$ 63$ (defining taxable income as gross income minus allowable deductions)

${ }^{155}$ See id. $\$ 151$ (listing allowable personal exemptions). 
pute the taxpayer's pre-credit tax. ${ }^{156}$ From this, the system subtracts credits to produce taxpayers' regular tax liability. Figure A summarizes this computation.

Figure A

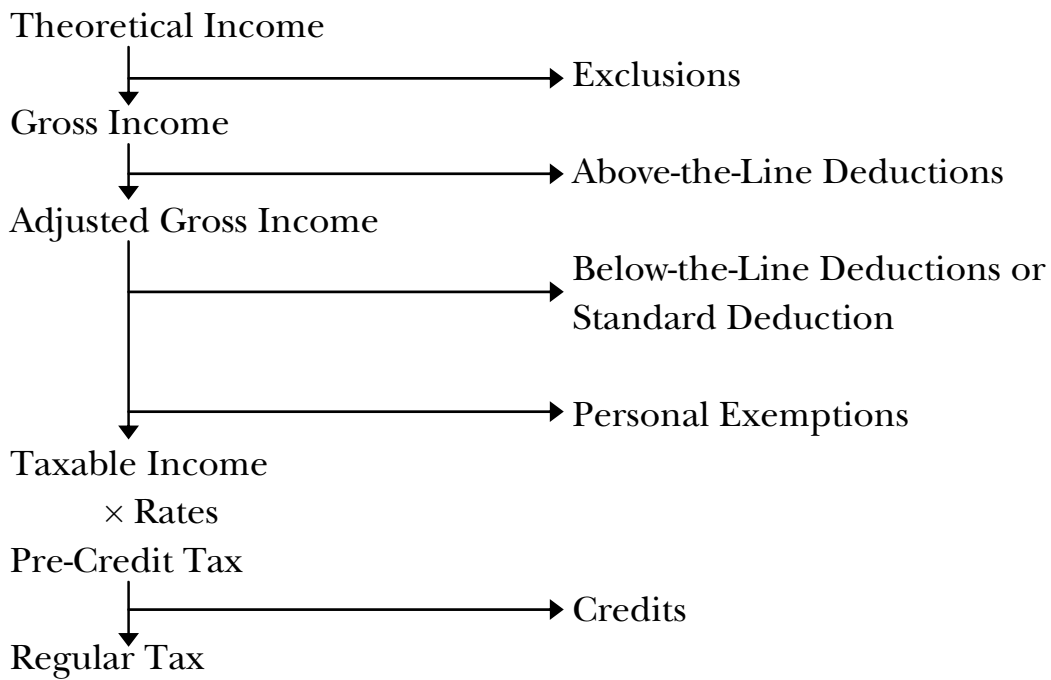

1. Standard Deduction and Floors

The standard deduction creates the first serious conceptual ambiguity in the computational process. On the one hand, it can be viewed as a simplifying provision, eliminating the need to list, substantiate, or audit deductions below a certain total. In effect the Internal Revenue Code says to the single return filer: "You may automatically claim $\$ 5,000$ of deductions without substantiating or even listing them. If you want to claim more, you need to be prepared to substantiate everything." Louis Kaplow, author of a leading article on the subject, treats simplification as the standard deduction's only necessary function. ${ }^{157}$

Alternatively, together with the personal exemption the standard deduction can be viewed as defining an initial income bracket with a ply).

${ }^{156}$ See id. $\S 1$ (listing tax brackets and the categories of taxpayers to which they ap-

${ }^{157}$ See Louis Kaplow, The Standard Deduction and Floors in the Income Tax, 50 TAX L. REv. 1, 1 (1994) (arguing that "distributional and revenue effects" are not "inherent" in the standard deduction). 
tax rate of zero: "We will tax your first $\$ 8,200$ of income $(\$ 5,000$ standard deduction plus $\$ 3,200$ personal exemption) at a rate of $0 \%$. We will then tax your next $\$ 7,300$ of income at a rate of $10 \%$." Under this view, the standard deduction is an inherent part of the progressive rate structure. As we have already noted, between 1971 and 1986 Congress explicitly adopted this perspective, replacing the term "standard deduction" with the more explicit term "zero bracket amount" in 1971, reintroducing the term "standard deduction" in 1986 primarily in response to taxpayer confusion. ${ }^{158}$

Unfortunately, these two views of the standard deduction have very different implications. If administrative simplification is its principal purpose, then all deductions should be below-the-line except, perhaps, deductions reliably verifiable through third party reporting. Taxpayers should be required either to list and prove all deductions, whatever their nature (again, with the possible exception of deductions reliably verifiable through third party reporting), or claim the standard deduction in lieu of any such listing. It is no less necessary or burdensome to substantiate most business deductions than it is to substantiate most personal deductions. Similarly, it is no less necessary or burdensome to substantiate the trade or business expenditures of independent contractors than it is to substantiate the identical expenditures of employees. But this also implies that if the standard deduction is taken in lieu of income-measuring deductions (which it should be if its purpose is administrative simplification), only an amount of a taxpayer's income equal to the personal exemption will routinely be exempt from tax. An administrative simplification view of the standard deduction therefore implies that the portion of every taxpayer's income that should be exempt from taxation is $\$ 3,200$ in 2005 dollars-probably less than most Americans' notion of a subsistence income.

If, on the other hand, the standard deduction and personal exemption collectively define a zero-rate bracket, the portion of every taxpayer's income that should be exempt from taxation is $\$ 8,200$ annually-not much, but better than $\$ 3,200$. In addition, this view of the standard deduction necessarily implies that all deductions required for the correct measurement of income should be above the line. ${ }^{159}$ That is, all income-measuring deductions should be allowed in

\footnotetext{
${ }^{158}$ See supra note 127 and accompanying text.

${ }^{159}$ We discuss the appropriate treatment of personal deductions in an ability-topay tax system in Part II.D.
} 
addition to, not in lieu of, the standard deduction. If the standard deduction and personal exemption define a zero-rate bracket, then requiring that an income-measuring deduction be taken in lieu of the standard deduction is equivalent to requiring that a taxpayer waive part of her zero-rate bracket as a condition of having her income measured correctly.

An example may serve to illustrate the foregoing points. Assume two unmarried taxpayers without dependents. $A$ has $\$ 10,000$ of gross income and no deductions. $B$ has $\$ 15,000$ of gross income, but incurs $\$ 5,000$ of current expenses to produce that income. In other words, she has exactly the same $\$ 10,000$ of net income as $A$ to split between her own needs and those of the federal government. Economically, $A$ and $B$ are identically situated. If B's $\$ 5,000$ expenditure is allowed as an above-the-line deduction, her adjusted gross income will be $\$ 10,000$. $A$ and $B$ will then face identical tax liabilities. In 2005, using the rate table given in Part II.B, each will owe $10 \%$ of $\$ 1,800$ - that is, each will owe $\$ 180$ in U.S. income tax. By contrast, if $B$ 's deduction is required to be taken below the line, $B$ will be forced to claim the deduction instead of, not in addition to, her standard deduction. In effect she will be required to waive a portion of her zero-rate bracket as a condition of having her income measured correctly. As a result, $B$ will report $\$ 5,000$ more taxable income than $A$, and will therefore owe $\$ 500$ more in income taxes, despite the fact that her economic situation is identical. In effect, of $B$ 's $\$ 10,000$ of economic income, only $\$ 3,200$ will be subject to a zero rate; the remainder will be taxable. If the standard deduction is an inherent part of the rate structure, the only correct way to treat deductions required for the correct measurement of income is to permit their deduction above the line.

Unfortunately, current law treats the standard deduction as a simplifying provision for some purposes and as part of the rate structure for others. In general, nonemployee trade or business expenses are deductible above the line, regardless of how administratively troublesome they may be. ${ }^{160}$ Thus with respect to such expenses, the standard deduction is treated as an inherent part of the rate structure. Identical expenses of employees, however, are only deductible below

${ }^{160}$ See I.R.C. $\$ 162(\mathrm{a})$ (2000) (allowing a deduction for trade or business expenses); $i d$. $\S 62(\mathrm{a})(1)$ (indicating that the deduction, with respect to non-employees, is above the line). 
the line ${ }^{161}$ regardless of how easy they might be to verify (union dues, for example, could easily be subject to computerized third party verification); for employees, apparently, the standard deduction is a simplification device. In the hypothetical in the preceding paragraph, if $B$ is classified as an independent contractor, her deduction will be above the line. If, on the other hand, she is classified as an employee, her deduction will only be allowed below the line-even if the expenditures are identical in purpose and amount. This same incoherence appears throughout $\S 62$, which tells us which deductions are above and which are below the line. Thus, costs of producing income apart from trade or business expenses are generally only deductible below the line; exceptions are made, however, for the costs of investments that generate rents or royalties ${ }^{162}$ and for losses from sales. ${ }^{163}$ Some personal deductions are above the line; some below. ${ }^{164}$ The net effect is to subject taxpayers in economically similar positions to different effective rates of tax for no apparent reason other than the lack of a consistent conception of the standard deduction's proper role.

A second mechanism is also sometimes thought to limit deductions for administrative simplification reasons-the "floor." Kaplow, again, treats simplification as the floor's only function. ${ }^{165}$ A floor is a requirement that deductions of a particular type exceed a certain amount before they can be taken at all. Once the floor is exceeded, only the amount by which the expense in question exceeds the floor is allowed as a deduction. Floors are often computed as a percentage of adjusted gross income. For example, deduction of medical expenses is permitted for regular tax purposes only if a taxpayer's qualified medical expenses exceed $7.5 \%$ of her adjusted gross income. Thus, if a taxpayer's adjusted gross income is $\$ 100,000$ and her qualified medical expenses are $\$ 10,000$, the effect of the floor is to allow her to deduct only the excess of that $\$ 10,000$ over $7.5 \%$ of $\$ 100,000-$ in

${ }^{161}$ See id. § 62(a)(1) (allowing trade and business expenses not incurred in "the performance of services by the taxpayer as an employee" to be deducted in computing adjusted gross income).

${ }^{162}$ Id. $\$ 62(\mathrm{a})(4)$.

${ }^{163} I d . \$ 62(\mathrm{a})(3)$.

${ }^{164}$ Currently, the following non-income-measuring deductions are above the line: deductions for alimony ( $\$ 215)$, moving expenses ( $\$ 217)$, Archer medical savings accounts $(\S 220)$, interest on education loans ( $(221)$, higher education expenses (§ 222), and health savings accounts $(\$ 223)$. All other non-income-measuring deductions are below the line. I.R.C. §62(a) (10), (15)-(19) (West Supp. 2005).

165 See Kaplow, supra note 157, at 1 (discussing floors as tools for income tax simplification, rather than for distributional or revenue purposes). We disagree with Kaplow on this issue. See infra text accompanying notes 226-27. 
other words, to allow her to deduct only $\$ 2,500$. Having surmounted this obstacle, the taxpayer still must get past the standard deduction. Only if her total below-the-line deductions exceed $\$ 5,000$ (for a single taxpayer) can she usefully claim the $\$ 2,500$ deduction.

In addition to floors on specific deductions, $\S 67$ imposes a $2 \%$ floor on "miscellaneous deductions" taken in the aggregate. Under this rule, a taxpayer can claim such deductions only to the extent they exceed $2 \%$ of her adjusted gross income. All but twelve specified below-the-line deductions are subject to this limitation. ${ }^{166}$ The practical effect is that below-the-line deductions other than the specified twelve are allowed only if they are significant in relation to a taxpayer's overall income; otherwise, they are ignored altogether-even if they are required for the correct measurement of a taxpayer's income.

Taken together, the standard deduction and $2 \%$ floor can produce very peculiar results. Consider, for example, the following facts, adapted from a 1994 Texas tort case, Behringer $v$. Behringer. ${ }^{167}$ The plaintiff's ex-wife ${ }^{168}$ repeatedly threatened plaintiff with death, told him that she could easily take out a contract on his life, and warned him constantly to be aware of his comings and goings. As a result, the plaintiff lived in fear, slept on the couch in order to have access to both the front and back doors, and kept a pistol beside him every night. The plaintiff sued her for intentional infliction of emotional distress and was awarded $\$ 13,000$ in damages. Although we do not know how much he was required to pay his attorney, let us assume that he paid $\$ 6,500$ in attorney's fees (that is, $50 \%$ of the award), leaving $\$ 6,500$ for himself.

Under current law, how would the plaintiff be taxed? First, the entire $\$ 13,000$ would be includible in his gross income. Second, his attorney's fees would be deductible for regular tax purposes, but only

${ }^{166}$ The twelve below-the-line deductions exempted from the $2 \%$ floor are the deductions for (1) interest under $\S 163$, (2) taxes under $\S 164$, (3) personal or investment casualty or theft losses or gambling losses under $\S 165$, (4) charitable contributions or set-asides under $\S \S 170$ and 642 (c), (5) medical expenses under $\S 213$, (6) impairment-related work expenses, (7) estate tax in the case of income in respect of a decedent under $\S 691(\mathrm{c})$, (8) losses or expenses in connection with personal property used in a short sale, (9) restoration of amounts previously included under claim of right under $\S 1341$, (10) annuity shortfalls under $\S 72(\mathrm{~b})(3),(11)$ amortizable bond premia under $\S 171$, and (12) expenses in connection with cooperative housing corporations under $\$ 216$. I.R.C. § 67 (b) (2000).

167884 S.W.2d 839, 842-44 (Tex. App. 1994).

${ }^{168}$ In the actual case, the defendant was the plaintiff's estranged wife. Id. at 839. We have changed this fact to avoid problems created by the rules governing separately filed returns of married individuals. 
below the line and only after application of the $2 \%$ floor. Assume that plaintiff's adjusted gross income was $\$ 100,000$; if so, the $2 \%$ floor would be $\$ 2,000$. If the plaintiff had no other below-the-line deductions, all of his attorney's fees would be effectively disallowed by reason of the $2 \%$ floor and the standard deduction. Under current law, plaintiff's marginal tax rate would be $28 \%$. He would therefore pay $28 \%$ of $\$ 13,000$ in U.S. income taxes by reason of his victory-or $\$ 3,640$. In other words, of the $\$ 13,000$ deemed by the jury to be his actual damages, he would get to keep only $\$ 2,860$ ( $\$ 13,000-\$ 6,500$ attorney's fees - $\$ 3,640$ U.S. income taxes). Under current regular tax rules, ${ }^{169}$ he would be taxed on his net economic income from the lawsuit $(\$ 6,500)$ at an effective rate of $56 \%$.

Tax cognoscenti may object that we have chosen atypical facts. But even if plaintiff is not "normal," there is no good reason to tax his recovery at an effective rate of 56\%-twice his nominal marginal rate. Plaintiff could easily retain documentation of his attorney's fees; there would be little administrative burden in confirming their amount. As applied to this plaintiff, the system makes no sense. The system should not be structured solely for the just taxation of "normal" taxpayers. And as we will see, the plaintiff in Behringer gets off easily compared to some.

\section{Personal Deductions, Phase-Outs, and Caps}

A second tension in our individual income tax computational structure is attributable to Surrey's insistence that all deviations from the correct measurement of "income" be viewed as subsidies distributed through the tax system for nontax reasons. ${ }^{170}$ This reframing was insightful as applied to business tax incentives. It had its most profound effects on the mechanical structure of the Internal Revenue Code, however, in the context of the individual income tax, where the tension between income and ability to pay is greater. So reframed, non-income-measuring deductions-including deductions intended to adjust for differences in ability to pay-are viewed as subsidies, not as inherent parts of the definition of an ability-to-pay tax base.

${ }^{169}$ Under alternative minimum tax rules, the result would be worse. See infra text accompanying note 195 .

${ }^{170}$ See supra note 106 and accompanying text. 
Surrey himself used medical expenses as an example. ${ }^{171}$ Let us return again to the quadriplegic taxpayer who makes $\$ 50,000$ but must spend $\$ 20,000$ to hire an assistant to deal with the basic tasks of everyday living. As ability-to-pay intuitions have influenced the interpretation of $\S 213$, this $\$ 20,000$ has come to qualify as a "medical ex-

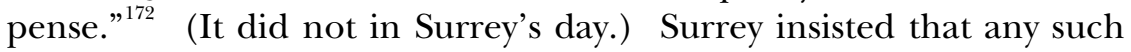
deduction be viewed as a nontax subsidy, not as an inherent part of the definition of taxpayer's ability to contribute to the expenses of government. ${ }^{173}$

So reframed, the deduction had what Surrey called an "upside down" effect: it subsidized wealthy taxpayers to a greater degree than it subsidized poor ones. ${ }^{174}$ Assume, for example, that taxpayers $A$ and $B$ each incur $\$ 1,000$ of deductible medical expenses. $A$ has an adjusted gross income of $\$ 100,000 ; B$ has an adjusted gross income of $\$ 10,000$. Ignoring any issues raised by the $7.5 \%$ floor or the standard deduction, the same $\$ 1,000$ medical expense deduction will subsidize $A$ 's medical expenses by $\$ 280$, but will subsidize $B$ 's by only $\$ 100$. Having thus reframed the issue, Surrey questioned the propriety of the deduction altogether. ${ }^{175}$

One technique Congress commonly uses to limit the consequences of this perceived problem while retaining the basic deduction concept is the "phase-out." A phase-out is a rule that limits one or more deductions once a taxpayer's income (typically adjusted gross income) moves past a specified point. The most important phase-out is the "overall limitation on itemized deductions." ${ }^{176}$ Under this provision, if an individual's adjusted gross income exceeds a so-called "applicable amount" (for 2005, the applicable amount was $\$ 72,975$ for married taxpayers filing separate returns and $\$ 145,950$ for all other taxpayers), then her below-the-line deductions are reduced by the lesser of $3 \%$ of the excess of adjusted gross income over the applicable amount, or $80 \%$ of those below-the-line deductions. ${ }^{177}$ The effect is to disallow all but $20 \%$ of affected below-the-line deductions at higher

${ }^{171}$ See SURREY, supra note 105, at 21-23 (noting that "most economists" would classify medical expense deductions as tax expenditures).

${ }^{172}$ See infra Part III.C.2.

${ }^{173}$ See SURREY, supra note 105, at 22 ("I find it difficult to accept [the] use of the income tax to provide financial assistance ....").

${ }^{174} I d$.

${ }^{175}$ See id. at 23 ("The focus should . . . be kept on those expenses and not be shifted to the income tax.").

${ }^{176}$ I.R.C. $\$ 68(2000)$.

${ }^{177}$ Id. $\S 68(\mathrm{a})$. 
income levels. All but three below-the-line deductions are subject to this phase-out; the favored three are the deductions for (1) medical expenses, (2) investment interest, and (3) casualty, theft, and gambling losses. ${ }^{178}$ Oddly, given its theoretical origins, the overall limitation on itemized deductions is not limited to non-income-measuring deductions-it applies equally to all below-the-line costs of producing income, and it does not apply to the medical expense "subsidy" singled out by Surrey when he articulated the underlying concern. The personal exemption similarly phases out at high income levels. ${ }^{179}$

Congress is clearly ambivalent about phase-outs. Under the Economic Growth and Tax Relief Reconciliation Act of 2001, both of the foregoing phase-outs - the overall limitation on itemized deductions and the phase-out of the personal exemption-themselves begin to phase out in 2006, and disappear completely in $2010 .^{180}$ Most of the 2001 Act itself then sunsets in 2011; in the absence of further legislation, therefore, the phase-out of the phase-outs will sunset, and the phase-outs themselves will magically reappear.

Recently, Congress has also begun to use "caps" to limit the perceived disproportionate benefit of personal deductions to higherincome taxpayers. Section 221, for example, permits the deduction of interest on certain higher education loans, but limits the dollar amount of such deductions to $\$ 2,500$ per year. ${ }^{181}$ None of the tax provisions of particular relevance to taxpayers with disability, however, currently includes a cap. We therefore spend no further space discussing caps here.

Finally, Congress often abandons the deduction format altogether in favor of credits. In Part III of this Article, for example, we explore the credit for household and dependent care services of $\S 21$, the credit for the elderly and the permanently and totally disabled of $\S 22$,

${ }^{178}$ Id. $\S 68(\mathrm{c})$.

179 See id. $\S 151(\mathrm{~d})(3)$. In 2005, the personal exemption phases out between $\$ 145,950$ and $\$ 268,450$ of income for single taxpayers, and between $\$ 218,950$ and $\$ 341,450$ of income for married taxpayers filing jointly. Rev. Proc. 2004-71, 2004-50 I.R.B. $970,974$.

${ }^{180}$ For 2006 and 2007, affected deductions are reduced by $2 \%$ instead of $3 \%$ of the excess of adjusted gross income over the applicable amount. For 2008 and 2009, the percentage reduction is only $1 \%$. Thereafter, the overall limitation on itemized deductions and the phase-out of personal exemptions both terminate. See I.R.C. $\$ \S$ 68(f), 151 (d) (3) (E) (Supp. I 2002) (articulating the new phase-out rules for itemized deductions).

181 I.R.C. $\$ 221$ deductions are also subject to phase-out at higher income levels. As is true for many other phase-outs, the 2001 Tax Act abolishes the I.R.C. $\$ 221$ phaseout effective in 2011. 
and the disabled access credit of $\S 44$. Unless otherwise limited, credits benefit taxpayers of all income classes equally, dollar for dollar. The problem with credits is that, to date at least, credits follow no inherent logic, each credit is unique in structure, each requires a separate reporting form, and each further complicates the income tax system in its own potentially annoying way. In addition, if the proper tax base is ability to pay, not income, and a credit really is intended to adjust for differences in ability to pay, then the credit mechanism is inappropriate from the outset, inasmuch as credits effect adjustments to tax, not to base.

\section{Exclusions}

Exclusions similarly help higher-income taxpayers more than they help lower-income taxpayers, although this fact is largely ignored even by members of Congress who worry about the same problem in connection with deductions. ${ }^{182}$ For example, as we discuss in greater detail below, tort damages to replace lost wages by reason of a disability resulting from physical injury are excludible under $\S 104$. Consider two single taxpayers without dependents, each incapacitated for one year by an automobile accident resulting in physical injury. Each recovers her lost annual salary from the tortfeasor: $\$ 100,000$ in the case of $A ; \$ 20,000$ in the case of $B$. Under comprehensive tax base theory, both recoveries should be taxable. But for charitable non-tax reasons, Congress excludes both recoveries. ${ }^{183}$ The value of this gift to $A$ in 2005, assuming no other income and no itemized deductions, is $\$ 20,210$. The value of the gift to $B$ on the same assumptions is $\$ 1,405$. This difference is hard to justify on ability-to-pay grounds or, indeed, under any normative theory.

Based on the foregoing facts, $A$ will pay no U.S. income taxes for the year. Contrast $A$ 's situation with that of $C$, an uninjured single taxpayer who earns $\$ 20,000$ the same year. Assuming no itemized deductions, in 2005 Congress requires $C$ to contribute $\$ 1,405$ of her $\$ 20,000$ towards the functioning of the federal government-

${ }^{182}$ The one exception of which we are aware is I.R.C. $\$ 86$, which partially phases out the exclusion for contributory Social Security benefits at higher income levels. See infra Part III.A.2.

${ }^{183}$ See I.R.C. $\$ 104(\mathrm{a})(2)$ (2000) (stating that gross income does not include compensation for injuries and sickness when received as damages); see also Comm'r v. Schleier, 515 U.S. 323, 329 (1995) ("[R] ecovery for lost wages is also excludable as being 'on account of personal injuries,' as long as the lost wages resulted from time in which the taxpayer was out of work as a result of her injuries."). 
compared with $\$ 0$ out of $\$ 100,000$ for $A$. Again, this is difficult to justify.

\section{Alternative Minimum Tax}

Largely at Surrey's urging, ${ }^{184}$ in 1969 Congress enacted a parallel tax system, the alternative minimum tax (AMT) system, ${ }^{185}$ that applies to every taxpayer, even though it does not always result in additional tax. This parallel system begins, like the regular system, with theoretical income. From theoretical income, it then takes exclusions and deductions computed under rules that are often different from the regular tax rules. For example, medical expenses are deductible for regular tax purposes to the extent they exceed $7.5 \%$ of adjusted gross income; for AMT purposes ${ }^{186}$ they are deductible only to the extent that they exceed $10 \%$ of adjusted gross income. ${ }^{187}$ Deductions subject to the $2 \%$ floor for regular tax purposes, even income-measuring deductions, are not deductible at all for AMT purposes. ${ }^{188}$ Depreciation is also computed under different rules. ${ }^{189}$ As a result, gain or loss is often different for AMT purposes than for regular tax purposes. When all is said and done, this recomputation produces something known as "alternative minimum taxable income" (AMTI) ${ }^{190}$

From alternative minimum taxable income, the taxpayer then subtracts something called the "exemption amount": \$58,000 in 2005 for married couples and surviving spouses and $\$ 42,250$ for other single taxpayers. ${ }^{191}$ This exemption amount is roughly the equivalent of a zero-bracket amount in the regular tax system, except that it phases out at higher income levels - that is, for married couples and surviving spouses whose AMTI exceeds $\$ 150,000$ and for other single taxpayers whose AMTI exceeds $\$ 112,500$. The result of this subtraction is known as the "taxable excess," which is the equivalent of "taxable income" in the regular tax system. The AMT then applies a very slightly

${ }^{184}$ See John W. Lee, III, The Capital Gains "Sieve" and the "Farce" of Progressivity 19211986, 1 Hastings Bus. L.J. 1, 37-40 (2005) (discussing the Surrey Tax Reform Studies and Proposals, which advocate for an alternative minimum tax).

${ }^{185}$ Tax Reform Act of 1969, Pub. L. No. 91-172, 83 Stat. 487 (1969).

${ }^{186}$ See supra text accompanying note 165 .

${ }^{187}$ I.R.C. $\$ 56$ (b) (1) (B) (2000).

${ }^{188} I d . \S 55(\mathrm{c})(2)$.

${ }^{189} I d . \$ 56(\mathrm{a})(1)$.

${ }^{190} I d . \S 55(\mathrm{~b})(2)$.

${ }^{191}$ I.R.C. $\$ 55(d)(1)$ (Supp. I 2002). These exemption amounts are currently scheduled to drop back down to $\$ 45,000$ and $\$ 33,750$, respectively, in 2006 . Id . 
progressive rate structure (beginning at $26 \%$ and jumping to $28 \%$ when the taxable excess reaches $\$ 175,000^{192}$ ) to the taxable excess, yielding the "tentative minimum tax." Every U.S. taxpayer must pay the greater of her regular tax liability and this tentative minimum tax, after adjustment for credits. ${ }^{193}$ Figure B summarizes this computation.

Figure B

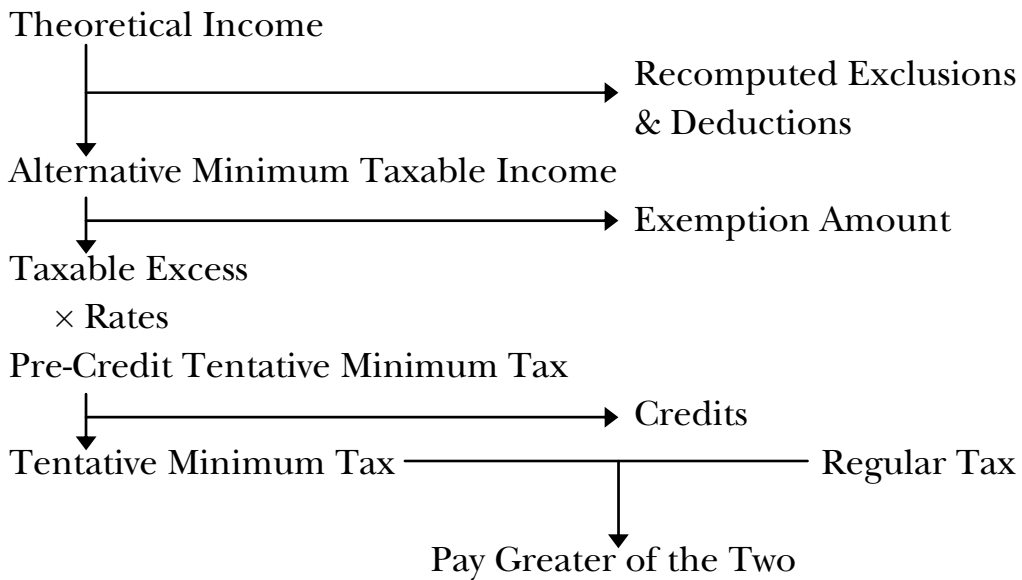

It was once thought that the AMT represented the theoretically pure tax system that Congress would enact if it only could. ${ }^{194}$ Politically popular but theoretically unjustified deductions and exclusions would disappear in the AMT computation. The result would be a more or less ideal flat tax on economic income, backing up the flawed but politically more visible regular system. Every taxpayer would therefore have to pay at least some minimum tax on economic income in excess of the exemption amount.

But the AMT can no longer be justified on this basis. Of the costs of producing income, only those above the line or exempt from the

${ }^{192}$ I.R.C. $\$ 55$ (b) (1) (A) (i) (2000). But see id. $\$ 55$ (b) (1)(A) (iii) (stating that the rate shifts at $\$ 87,500$ of taxable excess for married individuals filing separately).

${ }^{193}$ Technically, every taxpayer must pay her regular tax plus the excess of her tentative minimum tax over her regular tax (the excess is commonly referred to as her "alternative minimum tax"). Id. $\S 55(\mathrm{a})$. This is mathematically equivalent to requiring her to pay the greater of her tentative minimum tax and her regular tax. For a discussion of the credits available against the tentative minimum tax, see infra notes 20106 and accompanying text.

${ }^{194}$ See, e.g., Moran, supra note 151, at 228 (arguing that the AMT has not simplified tax computation). 
$2 \%$ floor are allowed for AMT purposes. The result is that many costs of producing income are now disallowed for AMT purposes; this in turn means that the AMT now taxes many types of income on a gross, rather than net, basis. Under the AMT, for example, the plaintiff in the Behringer case ${ }^{195}$ would not be allowed to deduct the costs of his attorney's fees no matter how large his recovery and regardless of the size of his adjusted gross income; he would be taxed simply on the gross amount awarded by the jury.

A particularly egregious example of this problem was reported by CBS News in 2003. ${ }^{196}$ Cindy Spina was the first female on her police force and, regrettably, endured discriminatory treatment from her coworkers. Her tires were slashed, her requests for backup were ignored, and she faced both formal and informal harassment from superiors and fellow officers. She finally quit and sued under Title VII of the Civil Rights Act of 1964, winning an award of $\$ 375,000$ compensatory damages, plus attorney's fees. Then the IRS came to collect its share. All of the attorney's fees, which had been paid directly to her attorney, were includible in Spina's gross income for federal income tax purposes, but no deduction was then allowed for those same fees in computing her AMT. Because in this context the AMT was imposed on gross, not net, income, Spina's federal income tax liability on her award was $\$ 475,000-\$ 100,000$ more than she had actually received, an effective rate of tax of $127 \%$ on her actual cash recovery. ${ }^{197}$ Congress has since remedied this problem with respect to claims of unlawful discrimination, ${ }^{198}$ but the problem remains in cases like Behringer. ${ }^{199}$ Indeed, the Supreme Court has since confirmed that Spina's tax treatment was proper. ${ }^{200}$

On the flip side, Congress has begun to allow credits to be taken against AMT liability. Prior to the Economic Growth and Tax Relief

\footnotetext{
${ }^{195}$ See supra notes 167-68 and accompanying text.

${ }^{196}$ See CBS News: IRS Turns Victory to Defeat (CBS television broadcast Jan. 12, 2004), available at http://www.cbsnews.com/stories/2004/01/12/eveningnews/main592779.shtml (last visited Mar. 23, 2006).

${ }^{197} I d$.

${ }^{198}$ I.R.C. $\$ 62(\mathrm{a})(20)$ (West Supp. 2005).

199 See Jeffrey H. Kahn, Beyond the Little Dutch Boy: An Argument for Structural Change in Tax Deduction Classification, 80 WASH. L. REV. 1, 13-15 (2005) (discussing the split among courts of appeals over whether the portion of the award that is paid as a contingent fee to the plaintiff's attorney should be included in the plaintiff's gross income).

${ }^{200}$ See Comm'r v. Banks, 125 S. Ct. 826, 833 (2005) (holding that when a litigant's recovery constitutes taxable income, such income includes the portion of recovery paid to the litigant's attorney as a contingent fee).
} 
Reconciliation Act of 2001 (EGTRRA), ${ }^{201} \S 26(\mathrm{a})(1)$ prohibited the use of any regular tax credits against the AMT. EGTRRA made two important changes. First, it permanently excepted three favored credits from this general rule: the credit for adoption expenses, ${ }^{202}$ the child tax credit, ${ }^{203}$ and the credit for IRA contributions. ${ }^{204}$ Second, it added $\S 26$ (a)(2), which allows all credits to be claimed against the AMT for taxable years beginning in 2000 through 2005. Originally, this "special rule," enacted as part of the Tax Relief Extension Act of $1999,{ }^{205}$ applied only to taxable years beginning in 2000 or 2001 . It has since been regularly extended each year, most recently by the Working Families Tax Relief Act of 2004, enacted October 4, 2004. ${ }^{206}$

As a result of the foregoing structural problems, the individual income tax system as a whole has become incoherent. We often complain about the tax system's complexity. But complexity is manageable so long as the universe has structure and each piece has a proper place in that structure. Today, Congress's decisions about where each piece will go no longer seem to follow rules. A proposal approved in 2003 by the House Ways and Means Committee would have permitted a floored and capped portion of charitable contributions to be deducted above the line by non-itemizers. ${ }^{207}$ Why? Because the Committee said so, that's why.

\section{Reframing the Income Tax, in Part, as a Tax on Ability To Pay}

We believe it would be useful for U.S. tax scholars to articulate more formally the moral intuitions that underlie continued popular and congressional adherence to ability to pay. ${ }^{208}$ Such an articulation

201 Pub. L. No. 107-16, 115 Stat. 38 (2001).

${ }^{202}$ I.R.C. $\$ 23$ (West Supp. 2005).

${ }^{203} I d . \$ 24$.

$204 I d . \$ 25 \mathrm{~B}$

${ }^{205}$ Pub. L. No. 106-170, 113 Stat. 1860 (1999).

${ }^{206}$ Pub. L. No. 108-311, 118 Stat. 1166 (2004).

207 1 H.R. REP. NO. 108-270, at 82-83 (2003).

208 This process has already begun. In a forthcoming paper, Deborah Geier argues that the U.S. income tax already is, in important respects, a tax on income available for discretionary use. See Deborah A. Geier, The Taxation of Income Available for Discretionary Use 4 (Cleveland State Univ., Research Paper No. 05-107, 2005), available at http://ssrn.com/abstract=696221 (observing that a "basic subsistence amount" is considered nondiscretionary and therefore free from tax). Fleming, Peroni, and Shay have used ability to pay to explain U.S. international tax rules. J. Clifton Fleming, Jr. et al., Fairness in International Taxation: The Ability-to-Pay Case for Taxing Worldwide Income, 5 FLA. TAX REV. 299, 301-03 (2001). Similarly, Joel Newman has used ability to pay to 
would help Congress systematize its implementation of those intuitions and thereby begin to move the individual income tax system back towards coherence. We do not mean to suggest that ability-topay analysis can answer all, or even a preponderance of, interesting individual income tax questions. So long as Congress and the electorate believe ability to pay to be relevant, however, we do not believe tax policy scholarship can properly reject or ignore it. Nor do we mean to suggest that scholars should abandon other projects, including utilitarian projects. We believe it is clear, however, that utilitarian theory often does not accurately model popular moral intuitions. Regardless of whether utilitarianism is correct in any ultimate sense, its failure to fit and justify popular moral intuitions limits its ability to explain, refine, or guide congressional action.

This Article will not attempt to offer any full-blown articulation of a non-utilitarian model of ability to pay. In 1966, however, the Canadian Royal Commission on Taxation made a simple and elegant beginning. ${ }^{209}$ The Commission started from a non-utilitarian premise: "In a democracy, equity questions ultimately must be resolved in terms of the shared values of the people. There is no higher authority." 210 Based on its perception of the values of the Canadian people, it concluded that taxes should be allocated in proportion to ability to pay. This, it concluded, required allocation "in proportion to the discretionary economic power of tax units." ${ }^{211}$ Discretionary economic power, in turn, it viewed as a function of three factors: differences in income, differences in family responsibilities, and differences in other nondiscretionary expenditures. ${ }^{212}$

Several features of the Commission's approach were noteworthy. First, it offered an integrated theory of both rate structure and basein other words, an integrated theory of the individual income tax system as a whole.

Second, its progressive rate structure did not assume declining marginal utility of its base, the shoals upon which earlier attempts to found progressivity in ability to pay had foundered; instead, it as-

explain the casualty loss rules. Joel S. Newman, Commentary, Of Taxes and Other Casualties, 34 HASTINGS L.J. 941, 943-45 (1983).

209 See 3 REPORT OF THE ROYAL COMMISSION ON TAXATION: TAXATION OF INCOME: PART A-TAXATION OF INDIVIDUALS AND FAMILIES 3-37 (1966) (recommending a tax structure for individuals and families founded on ability-to-pay principles).

${ }^{210} I d$. at 5 .

${ }^{211} I d$.

${ }^{212}$ Id. at 7-8. 
sumed constant marginal utility. But the base was not income; it was rather "income available for discretionary use." Some initial amount of income, the Commission assumed, was not available for discretionary use and was therefore not part of the base at all. "We are convinced ... that the first dollars of income should not be subject to tax. Clearly the fraction of income available for discretionary use is extraordinarily small for a family with an income of, say, \$2,000." ${ }^{213}$ Above some higher cut-off (it chose $\$ 100,000$ in 1966 Canadian dollars), it assumed that all tax base income was available for discretionary use. ${ }^{214}$ Between these two points, the Commission assumed that the percentage of income available for discretionary use rose proportionately with income. Thus, for example, half way between the top of the zero-bracket amount and $\$ 100,000$, the Commission's ideal rate schedule assumed that $50 \%$ of income in excess of the zero-bracket amount was available for discretionary use. ${ }^{215}$ These assumptions allowed the Commission to propose a flat tax on income available for discretionary use. The progressivity of its rate structure resulted solely from its assumption that at lower income levels less income would be available for discretionary use than at higher income levels. The tax to be imposed on income available for discretionary use was, in fact, the same at all levels—without exception.

Third, the base to which this rate structure was to be applied also reflected ability to pay. At any given level of income, the rate structure itself assumed that some standard percentage of expenditures would not be available for discretionary use. What this implied, however, was that only unusual nondiscretionary expenditures should be deductible in computing an ability-to-pay tax base. Among the nondiscretionary expenditures that should be deductible on this basis, the Commission believed, were extraordinary medical expenses, gifts to close relatives to provide them with support, and the special expenses of working mothers with young children. ${ }^{216}$

It is not our purpose to advocate wholesale adoption of the Commission's approach. The Commission's key insight, which we adopt in

213 Id. at 21.

${ }^{214} I d$. at 8 . The Commission's assumption of a linear relationship was simple but not inherent to its approach. A curve that approaches but never quite reaches $100 \%$ (in mathematical terms, asymptotic to $100 \%$ ) might capture our intuitions on this issue more accurately. Such a curve would more accurately reflect the existing U.S. progressive rate structure.

${ }^{215} I d$. at 11 tbl.7-1.

${ }^{216}$ Id. at 12. 
our analysis of current U.S. tax law, was that ordinary nondiscretionary expenditures should be treated as having been taken into account-in effect, as having been implicitly deducted-in deriving an appropriate rate structure. This means that for a tax to measure ability to pay correctly, only unusual nondiscretionary expenditures should be deductible in computing the base to which an ability-to-pay rate structure is then applied.

What would a more fully articulated ability-to-pay tax system look like? Although the question raises many complex issues beyond the scope of this Article, we expect that it would begin with comprehensive tax base income, accurately measured. All economic income would be includible; all current costs of producing such income would be currently deductible; all capital costs of producing such income would be amortized over realistic periods. Some initial amount of such income would be exempt from taxation-an amount large enough to permit the taxpayer to live a frugal but adequate life. We do not know what the correct number is, but would expect it to be higher than amounts commonly excluded from tax under the general welfare doctrine discussed in Part III.A.1 below. We note that the Department of Health and Human Services' 2005 poverty guideline for a single individual was $\$ 9,570 ; ;^{217}$ the Census Bureau's 2004 poverty threshold for a single individual under the age of sixty-five, $\$ 9,827 ;{ }^{218}$ the average Social Security disability insurance benefit in 2003, $\$ 10,344 ; ;^{219}$ the initial exempt amount for a single individual in Robert Hall and Alvin Rabushka's 1995 flat tax proposal, $\$ 9,500^{220}$ (\$12,361 in 2006 dollars) $;{ }^{221}$ and the initial exempt amount for a single individual in Rep. Dick Armey's 1995 flat tax proposal, $\$ 11,350^{222}$ (\$14,768 in 2006 dollars). ${ }^{223}$ The new initial exempt amount (which would, of course, have to vary with family size) might continue to be stated in terms of the familiar standard deduction and personal exemptions-

${ }^{217}$ U.S. Dep't of Health \& Human Servs., The 2005 HHS Poverty Guidelines: One Version of the [U.S.] Federal Poverty Measure, http://aspe.hhs.gov/poverty/ 05 poverty.shtml.

${ }^{218}$ U.S. Census Bureau, Poverty Thresholds 2004 (2005), http://www.census.gov/ hhes/www/poverty/threshld/thresh04.html.

219 ANNUAL STATISTICAL REPORT, supra note 20.

${ }^{220}$ Robert E. Hall \& Alvin Rabushka, The Flat Tax 59 fig.3.1 (2d ed. 1995).

${ }^{221}$ Converted using the Bureau of Labor Statistics CPI Inflation Calculator, http:/ /www.bls.gov/bls/inflation.htm (last visited Mar. 23, 2006).

${ }^{222} 141$ CONG. REC. E1461 (daily ed. July 19, 1995) (statement of Rep. Armey).

${ }^{223}$ Converted using the Bureau of Labor Statistics CPI Inflation Calculator, supra note 221 . 
although, as we discuss further below, any standard deduction used for this purpose would be available to all, itemizers and non-itemizers alike. $^{224}$

Above this initial exempt amount, we would expect moderately progressive rates, consistent with our sense of the American electorate's values. ${ }^{225}$ We would interpret these rates as reflecting a judgment that the additional goods and services most likely to be purchased with additional income are somewhat less essential, more discretionary, as one moves up the income scale. In other words, like the Canadian Royal Commission, we would interpret such rates as implementing the ideal of a flat tax on income available for discretionary use. Income in the top bracket would then be subject to the tax rate deemed appropriate for income completely available for discretionary use. We note, however, that although we would expect moderate progressivity, no particular rate structure above the initial exempt amount is necessary to any of the analysis that follows-a flat rate above the initial exempt amount would be consistent with our analysis as well.

We would expect existing personal deductions to be reframed or limited to reflect unusual nondiscretionary expenditures or losses. In many cases, this would require no changes whatever to existing law. State and local income taxes, for example, are nondiscretionary and vary markedly from state to state. Therefore, these amounts should arguably not be part of an ability-to-pay tax base. The medical expense deduction is already characterized by Congress as available only with respect to unusual expenses; the stated purpose of the $7.5 \%$ floor is to prevent the deduction of medical expenses deemed normal at any given level of income. ${ }^{226}$ The same is true of the deduction for casualty or theft losses. ${ }^{227}$ If personal deductions are allowed only with

${ }^{224}$ If the simplification function of the current standard deduction is deemed worth the complication that it brings to the tax computational structure, we envision a small "additional" standard deduction-say $\$ 1,000$. All non-computer-verifiable deductions, including business deductions, would be taken in lieu of this additional standard deduction.

${ }^{225}$ See, e.g., McCaffery \& Baron, supra note 150, at 1748-49 (arguing that theoretically optimal tax proposals are often rejected by the public because of the way they are presented). For a review of the problem of polling on this issue, and various results of those polls that have been taken, see Marjorie E. Kornhauser, Educating Ourselves Towards a Progressive (and Happier) Tax: A Commentary on Griffith's Progressive Taxation and Happiness, 45 B.C. L. REv. 1399, 1402-06 (2004) (noting that polls on taxation in which the public seems to oppose progressive taxation are particularly unreliable because of general public ignorance of tax issues, cogitative biases, and antitax rhetoric).

${ }^{226}$ H.R. REP. NO. 95-1445, at 43-44 (1978).

${ }^{227} 1$ S. REP. NO. $97-494$, at 115-16 (1982) 
respect to unusual non-discretionary expenditures and losses, we would expect similar floors to be instituted with respect to other personal deductions. Credits intended to reflect ability to pay would be restructured as floored deductions. Indeed, with the exception of the foreign tax credit, we believe that most non-business credits could comfortably be eliminated. Even exclusions can be reframed as reflecting differences in ability to pay. For example, the general welfare doctrine with respect to benefits in kind, discussed more fully below, can be viewed as acknowledging the nondiscretionary nature of those benefits. ${ }^{228}$

The effect of this restructuring and reframing would be to permit a radically simpler computational structure. All deductions would be allowed in addition to the standard deduction. ${ }^{229}$ The standard deduction would embody part of the core exempt amount and serve no other function. There would be no need for deduction caps or phaseouts, since deductions would constitute adjustments necessary to measure true ability to pay. The alternative minimum tax would be repealed.

Finally, and perhaps most importantly for purposes of this Article, such a tax system would allow simple targeted deductions to deal with differences in ability to pay. As we note in Part III.C.2, the medical expense deduction has already evolved to allow deduction of the extra costs necessarily incurred by people with disabilities in the course of major life activities, both personal and professional. We do not believe that major new provisions are required; reframing the individual tax in significant part as a tax on ability to pay, however, would clarify the role of deductions to reflect unusual nondiscretionary expenses in the system as a whole, obviating the need for many of the complexities of current law.

\section{TAX PROVISIONS OF PARTICULAR RELEVANCE TO PEOPLE WITH DISABILITIES}

It is against this background that we turn to current tax rules of particular relevance to people with disabilities. These rules are scattered throughout the Code and follow no overarching logic. To begin

\footnotetext{
${ }^{228}$ See infra Part III.A.1 (exploring the justifications and problems associated with excluding government subsidies from income).

${ }^{229}$ But see supra note 224 (addressing a proposal for simplification of the standard deduction whereby non-computer-verifiable deductions would be taken in lieu of an additional standard deduction).
} 
to make sense of them, we have organized our discussion into three parts, based on the various provisions' relationship to disability theory paradigms.

In Subpart A, we discuss provisions most easily justified by reference to the medical/charity paradigm. These provisions originated in the era in which that paradigm held sway; for the most part, they deviate from comprehensive tax base theory and do so primarily because their intended beneficiaries are perceived to be appropriate objects of pity and philanthropy. The problem for disability rights advocates is that while the standard tax theory rationale for these rules may seem offensive, they make life substantially easier for the disabled poor. We reframe these rules in terms of ability to pay and the human variation paradigm of disability rights. Where we cannot so reframe existing rules, we generally recommend their repeal.

In Subpart B, we discuss several newer provisions that appear to follow the civil rights paradigm. For the most part, these provisions are intended to facilitate the integration of people with disabilities into the mainstream, often by encouraging accommodation of people with disabilities even in the absence of actual enforcement of the disabilities rights acts. Their effects, for the most part, are modest in scope.

In Subpart C, we apply an ability-to-pay analysis consistent with the human variation paradigm to provisions arguably intended to deal with differences in ability to pay. The most important of these for people with disabilities is the deduction for medical expenses. Abilityto-pay intuitions have produced a marked expansion of the medical expense deduction to the point that today the medical expense deduction covers most extra expenses that people with disabilities incur in the basic tasks of everyday life.

\section{A. Provisions Consistent with the Medical/Charitable Model of Disability}

\section{General Welfare Doctrine}

Perhaps the single most important tax rule of particular relevance to people with disabilities, a set of rulings known collectively as the "general welfare doctrine," excludes most safety net payments from income-an issue of vital importance to people with disabilities. It also appears to justify exclusion of the value of governmental services from income-services provided pursuant to individual educational plans mandated by the IDEA, for example, or accommodated transportation services mandated by the ADA. Unfortunately, the doctrine 
is of uncertain legal foundation and uncertain scope. It is also inconsistent with both comprehensive tax base theory and modern disability rights paradigms.

The history of the doctrine is simply stated. In 1938, the IRS ruled that benefit payments under the then-new Social Security Act were not includible in gross income. ${ }^{230}$ Since then, it has ruled consistently, in a variety of contexts, ${ }^{231}$ that "[p]ayments by a governmental unit to an

${ }^{230}$ I.T. 3194, 1938-1 C.B. 114 (excluding lump sum payments under $\S 204$ (a) of the Social Security Act); I.T. 3229, 1938-2 C.B. 136 (excluding lump sum death payments under $\S 203$ and 204(b) of the Social Security Act); see also I.T. 3447, 1941-1 C.B. 191 (excluding monthly payments from the Federal Old Age and Survivors Insurance Trust Fund under $\S 202$ of the Social Security Act).

${ }^{231}$ I.T. 3230, 1938-2 C.B. 136 (excluding unemployment compensation); Rev. Rul. 131, 1953-2 C.B. 112 (excluding disaster relief payments); Rev. Rul. 55-652, 1955-2 C.B. 21 (excluding unemployment compensation payments to federal employees under Title XV of the Social Security Act); Rev. Rul. 57-102, 1957-1 C.B. 26 (excluding payments to blind persons under a Pennsylvania public assistance law); T.D. 6272, 1957-2 C.B. 30 (excluding pensions or annuities under the Social Security Act or the Railroad Retirement Act); Rev. Rul. 63-136, 1963-2 C.B. 19 (excluding benefit payments to individuals undergoing training or retraining under the Area Redevelopment Act or the Manpower Development and Training Act of 1962); Rev. Rul. 68-38, 1968-1 C.B. 446 (excluding payments under Title II-A of the Economic Opportunity Act of 1964 and the Manpower Development and Training Act of 1962); Rev. Rul. 70-217, 1970-1 C.B. 13 (superseding I.T. 3447 and excluding monthly payments under $\$ 202$ of Title II of the Social Security Act); Rev. Rul. 70-280, 1970-1 C.B. 13 (superseding I.T. 3230 and excluding benefits from the Federal Unemployment Trust Fund); Rev. Rul. 72-340, 1972-2 C.B. 31 (excluding stipends paid by city to unemployed probationers); Rev. Rul. 73-154, 1973-1 C.B. 40 (excluding unemployment benefits paid under the Emergency Unemployment Compensation Act of 1971); Rev. Rul. 74-74, 1974-1 C.B. 18 (excluding payments by the New York Crime Victims Compensation Board to victims of crime or their surviving spouses and dependents); Rev. Rul. 74-153, 1974-1 C.B. 20 (excluding payments to adoptive parents by Maryland State Department of Social Services for support of adoptive child); Rev. Rul. 74-205, 1974-1 C.B. 20 (excluding replacement housing payments under the Housing and Urban Development Act of 1968); Rev. Rul. 75-271, 1975-2 C.B. 23 (excluding mortgage assistance payments under the National Housing Act); Rev. Rul. 76-144, 1976-1 C.B. 17 (excluding grants under $\$ 408$ of the Disaster Relief Act Amendments of 1974); Rev. Rul. 76-229, 1976-1 C.B. 19 (excluding trade readjustment allowances paid to unemployed or adversely affected workers under the Trade Act of 1974); Rev. Rul. 76-373, 1976-2 C.B. 16 (excluding relocation payments under $\$ 105$ (a) (11) of Title I of the Housing and Community Development Act of 1974); Rev. Rul. 76-395, 1976-2 C.B. 16 (excluding home rehabilitation grants provided under the Housing and Community Development Act of 1974); Rev. Rul. 7777, 1977-1 C.B. 11 (excluding nonreimburseable grants under the Indian Financing Act of 1974, which was designed to stimulate Indian entrepreneurship and employment); Rev. Rul. 78-46, 1978-1 C.B. 22 (discharging the liability for repayment by the recipient of an interim benefit paid under the Public Safety Officers' Benefits Act of 1976 in the event no final benefit is paid); Rev. Rul. 78-170, 1978-1 C.B. 24 (excluding payments by Ohio on behalf of elderly and disabled persons against the cost of winter energy consumption); Rev. Rul. 98-19, 1998-1 C.B. 840 (excluding relocation payments under $\S 105(\mathrm{a})(11)$ of Title I of the Housing and Community Development Act of 
individual under a legislatively provided social benefit program for the promotion of the general welfare that are not basically for services rendered are not includible in the individual's gross income." ${ }^{232}$ A few scattered lower court decisions have acknowledged this exclusion. ${ }^{233}$ Justice Frankfurter's concurrence in United States v. Kaiser reviewed the history of the doctrine but, without either endorsing or rejecting it, found it inapplicable to strike benefits paid by unions to strikers. ${ }^{234}$ Tax scholars have occasionally noted the doctrine, ${ }^{235}$ but for the most part they have ignored it. By statute, Congress has overturned the doctrine with respect to two items, making unemployment and Social Security benefits wholly and partially taxable, respectively. ${ }^{236}$ Otherwise, the doctrine continues to function in obscurity, exempting from taxation an extraordinary variety of governmental benefits given in

1974, "funded under the 1997 Emergency Supplemental Appropriations Act for Recovery From Natural Disasters to an individual moving from a flood-damaged residence to another residence"); I.R.S. Notice 99-3, 1999-1 C.B. 271 (excluding Temporary Assistance to Needy Families payments).

${ }^{232}$ I.R.S. Notice 99-3, 1999-1 C.B. at 271.

233 See, e.g., Marshall v. Comm'r, 456 F.2d 1189, 1190 n.1 (2d Cir. 1972) (recognizing that Social Security benefits are not includible in gross income for income tax purposes) (citing Rev. Rul. 70-217 and Rev. Rul. 70-280); Bannon v. Comm'r, 99 T.C. 59, 63 (1992) (holding that payments from the State of California intended to provide nonmedical care for a totally disabled adult woman were taxable income when 'paid' to her mother, who cared for her; and acknowledging in dictum "the existence of the 'general welfare doctrine' of income exclusion”); Bailey v. Comm'r, 88 T.C. 1293, 1300-01 (1987) (noting that the social benefit program exclusion is limited to programs in which recipients are required to establish need and that the façade grant program at issue was not so limited); Graff v. Comm'r, 74 T.C. 743, 756 (1980) ("The payments made under Section 235 directly benefited low and moderate income families who were not capable of homeownership without assistance payments by the Federal Government. As such, the payments are treated as any other form of Government subsidy or benefit which is exempt from taxation.").

${ }^{234} 363$ U.S. 299, 305-26 (1960) (Frankfurter, J., concurring).

235 See, e.g., Michael J. Graetz \& Deborah H. Schenk, Federal Income TAXATION: PRINCIPLES AND POLICIES 134-35 (5th ed. 2005) (discussing the longstanding policy of excluding government benefits from gross income); PAUL R. MCDANiEl ET AL., Federal InCOME TAXATION 148-53 (5th ed. 2004) (noting that benefits based on financial need are generally excluded from gross income); DOUGLAS A. KAHN, FEDERAL INCOME TAX $\$ \S 2.4600-.4620$ (4th ed. 1999). Vada Waters Lindsey devotes one paragraph to the topic in Vada Waters Lindsey, The Burden of Being Poor: Increased Tax Liability? The Taxation of Self-Help Programs, 9 KAN. J.L. \& PUB. POL'Y 225, 244 (1999); and Fred Witt and William Lyons devote one sentence to Revenue Ruling 78-46 in Fred T. Witt, Jr. \& William H. Lyons, An Examination of the Tax Consequences of Discharge of Indebtedness, 10 VA. TAX REV. 1, 14 (1990). The only practitioner article we have found on the issue is Robert W. Wood \& Richard C. Morris, The General Welfare Exception to Gross Income, 109 TAX NOTES 203 (2005), which provides a broad overview of the general welfare exception in practice.

${ }^{236}$ I.R.C. $\$ \S 85,86(2000)$. 
cash or in kind to individuals with special needs. Benefits received under government programs intended to help the poor generally, and people with disabilities specifically, are, for the most part, excludible from gross income under this administratively created doctrine.

The legal foundation for the exclusion is unclear. ${ }^{237}$ The argument most often given is that Congress simply did not intend to tax this kind of receipt. ${ }^{238}$ While this might seem intuitively plausible, no one seems to have found any language in the legislative history of any part of the Code confirming any such general intention. Moreover, reliance on inferred intention can be dangerous, as is illustrated by the tale of Revenue Rulings 56-135 and 66-34. In Revenue Ruling 56135, the IRS concluded that payments received under the Panamanian analog of the U.S. Social Security system should be excludible as analogous to Social Security pensions, themselves then excludible under the general welfare doctrine. ${ }^{239}$ Then in 1966, the IRS explored the same question with respect to German retirement benefits. ${ }^{240}$ In the meantime, some researcher had located Senate Report language explaining $\S 37$ of the 1954 Code, now $§ 22$ (discussed in Part III.A.6), which created a credit for taxable retirement income:

Under existing law, benefits payable under the social security program and certain other retirement programs of the Federal Government are exempt from income tax. No similar exemption is accorded to persons receiving retirement pensions under other publicly administered programs, such as teachers, as well as persons who receive industrial pensions or provide independently for their old age. In order to adjust this differential tax treatment, the House bill grants an individual who is 65 years of age or over a credit against his tax liability equivalent to the tax, at the first bracket rate, on the amount of his retirement income up to $\$ 1,200$. . . Since some types of retirement pensions are already excluded from gross income, an adjustment is made to avoid duplication. The amount of retirement income up to $\$ 1,200$ which an individual receives

${ }^{237}$ Of the original Social Security rulings, see supra note 230, Lawrence Zelenak states: "All three rulings are remarkable for their utter lack of analysis. Each ruling describes the benefits in question and then states, without any explanation, that the benefits are not subject to income tax." Lawrence Zelenak, The Income Tax and the Costs of Earning a Living, 56 TAX L. REV. 39, 56 (2002).

${ }^{238}$ See, e.g., Rev. Rul. 57-1, 1957-1 C.B. 15 (ruling that strike benefits are includible in gross income). The IRS explained, "The benefits in these cases [involving unemployment compensation and Social Security benefits] were held not to constitute taxable income because it was believed that Congress intended that such benefits be not subject to tax. However, there is no evidence that Congress intended to exclude strike benefits from income." Id. at 16 . The ruling cited no authority for either assertion.

${ }^{239}$ Rev. Rul. 56-135, 1956-1 C.B. 56.

${ }^{240}$ Rev. Rul. 66-34, 1966-1 C.B. 22. 
is to be reduced, for purposes of computing the credit, by any social security, railroad retirement, military retirement pension, or other retirement pension which is excluded from gross income. ${ }^{241}$

There is no evidence that the staffer who wrote this language knew about the general welfare doctrine or Revenue Ruling 56-135, or that any member of Congress actually intended to change the outcome of that ruling. After reciting selectively edited portions of the Senate Report language, ${ }^{242}$ however, Revenue Ruling 66-34 observed that "no basis is known for attributing to Congress a belief that payments under the social security system of the Federal Republic of Germany or any other foreign social security system were not subject to the Federal income tax." 243 Therefore, the ruling concluded, benefits under the rest of the world's retirement systems were taxable. ${ }^{244}$ "Intent of Congress" seems a poorly defined foundation for the doctrine.

Nevertheless, it seems highly unlikely that Congress intended to subject governmental benefits and services to income taxation. As the Supreme Court observed in United States v. Kirby Lumber Co., the term "income" is to be construed in light of its "plain popular meaning." ${ }^{245}$ And as the Court observed in another context: "In a real sense, [a rent subsidy] no more embodies the attributes of income or profits than do welfare benefits, food stamps, or other government subsidies. ${ }^{246}$

Some further comfort can be drawn from the history of $\S 118$, the general welfare doctrine's corporate analog, which excludes governmental and other subsidies from corporate income. ${ }^{247}$ Section 118 de-

${ }^{241}$ S. REP. NO. 83-1622, as reprinted in 1954 U.S.C.C.A.N. 4621, 4637.

${ }^{242}$ The ruling omitted the qualifying phrase "such as teachers, as well as persons who receive industrial pensions or provide independently for their old age," thereby making the quoted language seem more plausibly to address foreign governmental retirement systems.

${ }^{243}$ Rev. Rul. 66-34, 1966-1 C.B. 23.

244 Id. at 24.

245284 U.S. 1, 3 (1931) (Holmes, J.) ("We see nothing to be gained by the discussion of judicial definitions. The defendant in error has realized within the year an accession to income, if we take words in their plain popular meaning, as they should be taken here.").

${ }^{246}$ United Hous. Found., Inc. v. Forman, 421 U.S. 837, 855 (1975) (addressing issues under the securities laws).

${ }^{247}$ See, e.g., Edwards v. Cuba R.R. Co., 268 U.S. 628, 632-33 (1925) (holding that subsidy payments are not includible in income); Comm'r v. May Dep't Stores Co., 519 F.2d 1154, 1155 (8th Cir. 1975) (holding that the value of land conveyed by a developer to a taxpayer in exchange for the taxpayer's agreement to maintain a retail store 
rives from the now-obsolete Eisner v. Macomber definition of "income" articulated by the Supreme Court in 1920: "gain derived from capital, from labor, or from both combined." ${ }^{248}$ In 1925, in Edwards v. Cuba Railroad Co., the Court ruled that subsidy payments made by the Cuban government to induce a corporate taxpayer to build and operate a railroad in Cuba were not "income" within the meaning of Eisner. ${ }^{249}$ Section 118 then codified Cuba Railroad and its progeny. ${ }^{250}$ The Eisner definition has long since been abandoned. ${ }^{251}$ Nevertheless, one might argue that congressional intent in the enactment of early incarnations of the Code should be understood in light of that definition.

Another possible argument is that benefits received under general welfare programs are "gifts" within the meaning of $\S 102$, which excludes gifts from income. The Supreme Court itself, in United States v. Kaiser, upheld a jury finding that strike assistance paid by a union to participating strikers was an excludible gift. ${ }^{252}$ In his concurrence, Justice Frankfurter justified three IRS rulings on such a gift rationale: (1) Special Ruling of May 11, 1952, ${ }^{253}$ holding that disaster relief in the form of food and clothing from the American Red Cross constituted a "gift," not income, ${ }^{254}$ (2) Revenue Ruling $131,{ }^{255}$ holding that cash disaster relief from a corporation to its employees was similarly

on the land was not includible); G.M. Trading Corp. v. Comm'r, 121 F.3d 977, 980 (5th Cir. 1997) (recognizing that the excess value of property given by the Mexican government to a company is not includible in the company's gross income); Frank Holton \& Co. v. Comm'r, 10 B.T.A. 1317, 1323 (1928) (holding that land transferred to a company to construct a factory was not taxable income), acq. in result, Rev. Rul. 68-558, 1968-2 C.B. 415. See generally, Note, Taxation of Nonshareholder Contributions to Corporate Capital, 82 HARV. L. REV. 619 (1969) (discussing the exclusion from income of contributions to capital by nonshareholders).

248252 U.S. 189, 207 (1920).

249268 U.S. at 633.

${ }^{250}$ See Note, supra note 247, at 621-25 (discussing the history of this rule).

${ }^{251}$ See, e.g., Comm'r v. Glenshaw Glass Co., 348 U.S. 426, 430 (1955) (refusing to apply the Eisner definition of income).

2523 U.S. 299, 304-05 (1960).

${ }^{253}$ Justice Frankfurter cited this ruling to "1952-5 CCH Federal Tax Reports I 6196." Id. at 320-21 (Frankfurter, J., concurring). We have not been able to locate any such officially reported ruling.

${ }^{254}$ Regarding the ruling, Justice Frankfurter stated:

The relief was referred to as a 'gift' in the ruling, and it was simply asserted, without explication, that, as to the food and clothing, 'nor do they represent taxable income.' ... It is not unreasonable to attribute this conclusion to an application of the principle of 'gift,' in light of the nature of the Red Cross as a charitable organization.

Id. at 312

${ }^{255}$ Rev. Rul. 131, 1953-2 C.B. 112. 
"gratuitous and spontaneous" and therefore not income, ${ }^{256}$ and (3) Revenue Ruling $57-102,{ }^{257}$ holding that payments to blind persons under Pennsylvania's public assistance law were excludible. Only the third involved payments by a governmental unit under a legislatively provided social benefit program. All three, however, provide some support for excluding general welfare payments as "gifts." With regard to aid to the blind, Frankfurter observed, "it may well have been treated by the Commissioner as a gift, and not unreasonably so, for the blind are a common object of charity." 258

Finally, by overruling the doctrine only with respect to unemployment and Social Security benefits, Congress may be deemed to have ratified the IRS's prior administrative position in other regards. Even if that position had no congressional sanction prior to such ratification, it may have such sanction today.

The scope of the doctrine is itself equally unclear. Although today the doctrine is commonly described as excluding certain "payments by a governmental unit," 259 none of the possible rationales for the exclusion-plain popular meaning, Eisner, gift, or ratification-is limited inherently to "payments" or to governmental action. Taxpayers receive an extraordinary range of governmental services every daypublic education, subsidized public transportation, police protection, and disaster relief, to name but a few. These services are clearly income under comprehensive tax base theory; nevertheless, they have never been thought to be includible. Some rule must exclude their value from income. The general welfare doctrine seems the most likely candidate.

Application of the doctrine to receipts in kind, however, creates its own problems. Both the courts and the IRS have attempted to limit the doctrine, at least as applied to payments of cash, to situations involving documented individual need. In Bailey $v$. Commissioner, for example, a taxpayer received a grant from the city's urban renewal agency to restore the façade on a building he owned. ${ }^{260}$ In consideration, the taxpayer granted the agency an easement to enter his prop-

${ }^{256}$ Describing the ruling, Justice Frankfurter stated: "In light of the circumstances of that case, involving disaster relief, it is natural to suppose that this language reflects an application of the principle that 'gifts' are not part of gross income." Kaiser, 363 U.S. at 309.

${ }^{257}$ Rev. Rul. 57-102, 1957-1 C.B. 26.

${ }^{258}$ Kaiser, 363 U.S. at 314.

${ }^{259}$ See supra note 232 and accompanying text (describing this doctrine).

${ }^{260} 88$ T.C. 1293,1293 (1987). 
erty to repair the façade at his expense and agreed not to modify the façade without the agency's approval. The taxpayer sought to exclude the grant under the general welfare doctrine. The Court disagreed, ${ }^{261}$ noting:

In each of respondent's revenue rulings in which the general welfare doctrine has been applied, the grant was received under a program requiring the individual recipient to establish need.... Grants received under social welfare programs that did not require recipients to establish individual need have not qualified under respondent's rulings for tax exempt status under the general welfare doctrine. ${ }^{262}$

Similarly, in Revenue Ruling 80-330, a taxpayer received a grant under the National Historic Preservation Act of 1966 to restore an historic house. The Service declined to apply the general welfare doctrine:

The payments in this case are distinguished from welfare program payments .... [P] ayments [here] are not based on an individual recipient's personal financial status, health, educational background, or employment status, nor are they intended to improve the living conditions of low-income homeowners. ... Thus, the payments are not made under a social benefit program for the promotion of general welfare. ${ }^{263}$

But if the doctrine also applies to receipt of governmental services in kind, individual need-at least in the conventional charitable sense-cannot be a prerequisite to exclusion. Public education and subsidized public transportation, for example, are available to the rich as well as to the poor, yet their value has never been thought to be taxable.

Under standard tax theory, justification of the exclusion is also problematic. Governmental benefits and services are clearly income to taxpayers who receive them. Standard tax theory therefore requires that we look outside the tax system for the doctrine's justification. To the extent that the doctrine exempts benefits to people with disabilities, it appears to do so because they are the natural objects of charity - that is, for reasons founded in the medical/charity paradigm rejected by the disability rights community. This means that the general welfare doctrine-perhaps the single most important tax rule for

${ }^{261}$ The Court nevertheless excluded the façade grant from the taxpayer's income on the ground that he lacked "complete dominion" over the façade-in effect, on the ground that the grant benefited the agency, not the taxpayer. Id. at 1302.

${ }^{262} I d$. at 1300 .

${ }^{263}$ Rev. Rul. 80-330, 1980-2 C.B. 29, made obsolete by Rev. Rul. 82-195, 1982-2 C.B. 34 . 
people with disabilities-is inconsistent with both standard tax theory and modern disability rights paradigms.

Fortunately, the doctrine can be reframed in terms consistent with the human variation paradigm under an ability-to-pay theory of the income tax. For this purpose, we break the doctrine into two parts: a rule excluding benefits in kind and a rule excluding payments of cash.

Benefits in kind should, of course, be includible in income. At the same time, benefits in kind are typically provided because governments believe they are needed-in effect, because governments believe they are nondiscretionary. Although some parents might choose not to educate their children, for example, or although some parents of children with disabilities might choose not to provide their children with the special services they need, the government has decided that such services are essential and for this reason provides them free of charge. In a first-best ability-to-pay system, therefore, the value of such services would be includible, but their cost would be deductible. A simple exclusion produces the same bottom-line result.

The same argument cannot be made with respect to payments of cash. In a first-best ability-to-pay system, however, although such payments would be includible, an adequate initial amount of income would also be exempt. Our current zero-bracket amount is probably not adequate. Assuming an adequate zero-bracket exemption, most recipients of need-based general welfare payments would unlikely rise to taxpaying levels in a first-best ability-to-pay system. In a second-best world, therefore, exclusion of general welfare payments can be justified as well, so long as the exclusion is limited to payments based on individual need.

\section{Partial Exclusion of Social Security Disability Insurance and} Full Exclusion of Supplemental Security Income

The general welfare doctrine evolved out of rulings that Social Security benefits were excluded from income. The subsequent history of the taxability of such benefits reinforces our analysis of the general welfare doctrine, given above. As we have noted, two principal benefits are available under Social Security to people with disabilities: Social Security disability insurance (SSDI) and Supplemental Security Income $(\mathrm{SSI}){ }^{264}$ The disability insurance program is contributory in form-that is, benefits are based on contributions made by or on be-

264 See supra note 18 and accompanying text. 
half of the beneficiary. Advocates for senior Americans have therefore argued that the contributory portions of Social Security should be treated as insurance, not as welfare. ${ }^{265}$ The supplemental income program, by contrast, is clearly a welfare program. ${ }^{26}$

For this reason, Congress enacted the Social Security Amendments of 1983 to distinguish between the tax treatments of these two programs. ${ }^{267}$ Under $\$ 86$, contributory Social Security insurance benefits, including disability insurance benefits, now may be at least partially taxable. If a taxpayer has no other source of income, such benefits remain nontaxable. As a taxpayer's "modified adjusted gross income" ${ }^{268}$ increases, however, first $50 \%$ and then $85 \%$ of contributory Social Security insurance benefits are included in gross income. ${ }^{269}$

${ }^{265}$ E.g., Nancy J. Altman, The Reconciliation of Retirement Security and Tax Policies: A Response to Professor Graetz, 136 U. PA. L. REV. 1419, 1427-29 (1988); Wilbur J. Cohen, The Development of the Social Security Act of 1935: Reflections Some 50 Years Later, 6 Soc. SEC. REP. SERV. 933, 951-53 (1984); Lance Liebman, The Definition of Disability in Social Security and Supplemental Security Income: Drawing the Bounds of Social Welfare Estates, 89 HARV. L. REV. 833, 836-39 (1976).

${ }^{266}$ See supra note 21 and accompanying text.

${ }^{267}$ Social Security Amendments of 1983, Pub. L. No. 98-21, 97 Stat. 65.

268 As defined by $\S 86$ (b) (2), "modified adjusted gross income" equals adjusted gross income (not including Social Security or Tier 1 Railroad Retirement benefits) without regard to:

(1) the exclusion for interest on savings bonds used to finance education $(\$ 135)$;

(2) the exclusion of employer paid adoption expenses (\$ 137);

(3) the deduction for interest on qualified educational loans (§ 221);

(4) the deduction for qualified tuition and higher education expenses after 2001 and before 2006 ( $\$ 222)$

(5) the foreign earned income exclusion $(§ 911)$;

(6) the exclusion of income from U.S. possessions ( $\$ 931)$; or

(7) the exclusion of income from Puerto Rico (\$933).

I.R.C. $\$ 86$ (b) (2) (2000 \& Supp. II 2002).

${ }^{269}$ Specifically, if the sum of a taxpayer's modified adjusted gross income plus onehalf of her Social Security benefits exceeds a "base amount," the lesser of one-half of such excess or one-half of her Social Security benefits is includible. I.R.C. $§ 86$ (a) (1) (2000). For this purpose, "base amount" is defined as $\$ 25,000$ for a single taxpayer, $\$ 32,000$ for a married taxpayer filing jointly, and zero for a married taxpayer filing separately if she lives with her spouse during the year. $I d . \S 86(\mathrm{c})(1)$. In addition, if the sum of the taxpayer's modified adjusted gross income plus one-half of her Social Security benefits exceeds an "adjusted base amount," a further amount equal to the lesser of (1) $85 \%$ of her Social Security benefits or (2) the sum of (a) $85 \%$ of that excess and (b) the lesser of the first inclusion or an amount equal to one-half of the difference between the adjusted base amount and the base amount is includible. Id. $\S$ 86 (a) (2). For this purpose, "adjusted base amount" is defined as $\$ 34,000$ for a single taxpayer, $\$ 44,000$ for a married taxpayer filing jointly, and zero for a married taxpayer filing separately if she does not live apart from her spouse during the year. Id. $\$ 86$ (c). Stated somewhat more simply, if a recipient's modified adjustable gross income plus 
This $85 \%$ inclusion percentage reflects an attempt to bring the taxation of such benefits into conformity with comprehensive tax base theory. Roughly $15 \%$ of such benefits, on average, represent contributions previously made to the Social Security system. In theory, therefore, $15 \%$ of a recipient's benefits constitute a return of capital and should not be taxed. ${ }^{270}$ The remaining $85 \%$, however, represent benefits not previously paid for and should therefore be subject to taxation.

In a first-best ability-to-pay tax system, the same $85 \%$ of contributory Social Security benefits would be includible in all recipients' incomes, but would not ultimately be taxed to lower-income recipients because such a system would exempt an adequate initial amount of income. Section 86 effects a respectable second-best solution. Full exclusion is limited to low-income taxpayers, who would not be taxed in any event under a first-best ability-to-pay regime.

Supplemental Security Income payments, by contrast, are not subject to $\S 86$ and remain fully excludible under the general welfare doctrine. From a conventional tax perspective, the exclusion of these payments must be justified as a subsidy to recipients in need. From a disability theory perspective, the exclusion is a holdover from the days of the medical/charity paradigm. Recipients are objects of pity and therefore deserving of charity; the tax exclusion is an additional act of charity. As we have already argued in connection with respect to the general welfare doctrine generally, however, application of that doctrine to SSI approximates a first-best ability-to-pay system in a secondbest world-consistent with both ability to pay and the modern human variation model of disability rights.

\section{Exclusion of Veterans' Disability Benefits}

Although benefits to disabled veterans raise issues beyond the scope of this Article, they are sufficiently large in dollar terms that we would be remiss to ignore them altogether. Currently, the federal government offers two cash benefit programs for disabled veterans.

\footnotetext{
one-half of her benefits exceeds her base amount, then up to $50 \%$ of her benefits are taxable; and if her modified adjustable gross income plus one-half of her benefits exceeds her adjusted base amount, then up to $85 \%$ of her benefits are taxable. Neither "base amount" nor "adjusted base amount" is indexed for inflation.

${ }^{270}$ This is not strictly true. Of the $15 \%$ contributed, only half is generally contributed out of after-tax dollars by a taxpayer. The other half is contributed by a taxpayer's employer or by the taxpayer out of pre-tax dollars. In theory, only the half reflecting after-tax contributions should be treated as return of capital.
} 
First, disability compensation is paid because of disabilities incurred or aggravated during active military service. The amounts paid vary with the degree of disability and number of dependents ${ }^{271}$ and may include housing assistance for the purchase or remodeling of an adapted home or automobile. ${ }^{272}$ Second, an enhanced pension is available to veterans who are permanently and totally disabled or are over sixty-five years of age if they served during a period of war. ${ }^{273}$ This second program supplements amounts awarded under other retirement programs, including Social Security. In addition to these two cash benefit programs, the federal government provides numerous other benefits to veterans generally, including education and training, vocational rehabilitation and employment, home loan guaranties, life insurance, burial benefits, and survivor benefits. ${ }^{274}$

Section 134 was added in 1986 to consolidate rules for the tax treatment of military benefits. ${ }^{275}$ It excludes from gross income any military benefit other than personal use of a military vehicle if such benefit was excludible as of September 9, 1986, under any law, regulation, or administrative practice-presumably including the general welfare doctrine. The Conference Committee Report to the Tax Reform Act of 1986 listed thirty-one specific benefits authorized and excludible as of that date, ${ }^{276}$ and stated that it intended its list to be ex-

${ }^{271}$ For 2005, the monthly compensation rates varied from $\$ 108$ per month for $10 \%$ disability up to $\$ 2,299$ per month for $100 \%$ disability. Additional funds were available for spouses and children depending on the disability rating. OFFICE OF PUB. AFFAIRS, DEP'T OF VETERANS AFFAIRS, FEDERAL BENEFITS FOR VETERANS AND DEPENDENTS 73 (2005).

${ }^{272}$ For 2005 , the VA had the discretion to approve a grant up to $\$ 50,000$ for certain types of severe disabilities and up to $\$ 10,000$ for others. Id. at 21-22.

${ }^{273}$ For 2005, the Improved Disability Pension amounts ranged from an annual rate of $\$ 10,162$ for a veteran with no dependents to $\$ 20,099$ if the veteran required regular aid and attendance. Additional dependents added additional funds. Id. at 73 .

${ }^{274}$ See generally $i d$. (detailing eligibility for federal benefit programs for veterans and their dependents).

${ }^{275}$ Tax Reform Act of 1986, Pub. L. No. 99-514, tit. XI, § 1168(a), 100 Stat. 2085, 2512 (codified as amended at 26 U.S.C. $\$ 134$ (2000)).

${ }^{276}$ H.R. CONF. REP. NO. 99-841, as reprinted in 1986 U.S.C.C.A.N. 4075, 4636. The Committee listed (1) veterans' benefits under 28 U.S.C. $\$ 3101,(2)$ medical benefits under 50 U.S.C. $\$ 2005$ or 10 U.S.C. $\$ \S 1071-1083$, (3) combat zone compensation and combat related benefits under 37 U.S.C. $\$ 310$, (4) disability benefits under 10 U.S.C. ch. 61 , (5) professional education under 10 U.S.C. $\$ \S 203$, 205, or 141, (6) moving and storage under 37 U.S.C. $\$ \S 404-412$, (7) group term life insurance under 38 U.S.C. $\S \S 404-412$, (8) premiums for survivor and retirement protection plans under 10 U.S.C. $\S \S 1445-1447$, (9) mustering out payments under 10 U.S.C. $§ 771 \mathrm{a}(\mathrm{b})(3)$, (10) subsistence allowances under 37 U.S.C. $\$ \S 209$ or 402, (11) uniform allowances under 37 U.S.C. $\$ \S 415-418$, (12) housing allowances under 37 U.S.C. $\$ \S 403,403 \mathrm{a}$, and 405, 
haustive-unless, it noted, some benefit had unintentionally been left out. All veterans' disability benefits authorized as of that date are therefore excluded from gross income for federal income tax purposes. $^{277}$

The exclusion of military disability benefits is, again, inconsistent with comprehensive tax base theory. It represents, rather, a combination of additional compensation for military service, gratitude for the sacrifices members of the Armed Forces make for this country, and charitable solicitude for those killed or disabled in its service. Because veterans are former employees of the United States and because of this admixture of motivations, we view the exclusion of veterans' benefits, including veterans' disability benefits, as sui generis, and ignore them hereafter in our analysis.

\section{Exclusion of Income Replacement Benefits from Disability and Other "Health and Accident" Insurance}

As the preceding sections illustrate, people with disabilities who receive governmental support payments, other than unemployment or contributory Social Security benefits, are generally permitted to exclude such payments in computing federal taxable income. Although nominally inconsistent with both comprehensive tax base theory and ability to pay, this exclusion can probably be reconciled with an abilityto-pay theory of taxation because such governmental payments are almost always limited to low-income recipients or recipients with un-

(13) overseas cost-of-living allowances under 37 U.S.C. $\$ 405$, (14) evacuation allowances under 37 U.S.C. $§ 405 a$, (15) family separation allowances under 37 U.S.C. $§ 427$, (16) death gratuities under 10 U.S.C. $\$ \$ 1475-1480$, (17) internment allowances under 10 U.S.C. $\$ \S 1481-1482$, (18) travel for consecutive overseas tours under 37 U.S.C. $\S 411$, (19) emergency assistance under 10 U.S.C. $\$ 133$ and 37 U.S.C. ch. 1, (20) family counseling services under 10 U.S.C. $\$ 133$, (21) defense counsel under 10 U.S.C. $\S \S 133,801-940,1181-1187$, (22) burial and death services under 10 U.S.C. $\S \S 1481-$ 1482, (23) educational assistance under 10 U.S.C. $\$ 141$ and 37 U.S.C. $\$ \S 203$ or 209, (24) dependent education under 20 U.S.C. $\$ 921$ and 10 U.S.C. $\$ 7204$, (25) dental care for military dependents under 10 U.S.C. $\$ \$ 1074$ or 1078 , (26) temporary lodging under 37 U.S.C. $\$ 404 \mathrm{a}$, (27) travel to a designated place in conjunction with reassignment in a dependent-restricted status under 37 U.S.C. $§ 406,(28)$ travel in lieu of moving dependents during ship overhaul or inactivation under 37 U.S.C. $§ 406 \mathrm{~b}$, (29) annual round trip for dependent students under 37 U.S.C. $\$ 430$, (30) travel for consecutive overseas tours under 37 U.S.C. $\S 411 \mathrm{~b}$, and (31) travel of dependents to a burial site under 37 U.S.C. $§ 411 f$.

${ }^{277}$ For a discussion of the subsequent history of I.R.C. $\$ 134$, see Theodore Paul Manno, Federal Income Taxation of Soldiers, Sailors, Airmen and Marines, 50 S.D. L. REv. 293, 296-97 (2005). 
usual needs. The tax treatment of private income support for people with disabilities, which is not so limited, is harder to justify.

Section 104(a)(3) governs the taxability of amounts received through health or accident insurance for personal injury or sickness, other than insurance provided tax-free by an employer. In general, all such receipts are excluded, including amounts intended to compensate taxpayers for lost income. For example, if a taxpayer is disabled in a traffic accident and is compensated for her lost income through a no-fault auto insurance policy, that compensation is completely taxexempt even if it exceeds the taxpayer's investment in that insurance policy-indeed, even if the policy belongs to someone else. Similarly, if a taxpayer receives income replacement benefits under a disability insurance policy, such replacement income is tax-exempt if premiums on the policy are paid with after-tax dollars. ${ }^{278}$

This blanket exclusion can produce peculiar results. Assume, for example, that two single taxpayers are each disabled to a degree sufficient to trigger benefits under their respective disability insurance policies. Each receives benefits equal to $70 \%$ of her lost salary: $\$ 70,000$ in the case of $A ; \$ 14,000$ in the case of $B$. Under comprehensive tax base theory, both recoveries should be taxable to the extent they exceed the taxpayers' investments in their policies. Assume that the two have invested proportionate amounts in their policies: $A$,

${ }^{278}$ I.R.C. $\$ 104(a)(3)(2000)$. The exclusion provided by $\$ 104(a)(3)$ is not available if a taxpayer's employer pays the premiums and the value of those premiums is excluded from the taxpayer's income. Since health and accident insurance premiums paid by one's employer are generally excludible, I.R.C. $\$ 106$ (a) (2000), this means that benefits paid through employer-provided health and accident insurance plans are generally ineligible for exclusion under $\$ 104(\mathrm{a})(3)$. Instead, they must be excluded under $\S 105$ (b), which is limited to amounts paid for medical care. I.R.C. $\S 105$ (b) (2000). In other words, income replacement benefits through health and accident insurance plans are excludible only if someone other than a taxpayer's employer pays the premiums. Employee benefit plans commonly deal with this problem by offering two separate policies qualifying as "health and accident insurance" for purposes of $\S$ 104(a) (3). The first is conventional health insurance, premiums for which are paid with pre-tax (that is, excludible) income. Since conventional health insurance covers medical care, not income replacement, all benefits are excludible under $\S 105$ (b). The second is disability insurance, premiums for which are commonly paid with aftertax income. David L. Raish, Cafeteria Plans, 397 TAX. MGMT. PorTFOLIO A-44 (1971). Disability insurance replaces lost income if the employee becomes disabled, but because the premiums are treated as having been paid by the employee, not the employer, the benefits, when received, are excluded from the employee's income. Rev. Rul. 2004-55, 2004-1 C.B. 1081, 1082; see also Benefits Provided Under Certain Employee Benefit Plans, 54 Fed. Reg. 9460, 9500 (Mar. 7, 1989) (codified at 26 C.F.R. pt. 1) (requiring taxpayers to include in gross income any taxable benefits the employee could have received under a benefit plan). 
$\$ 3,000$; and $B, \$ 600$. But for charitable non-tax reasons, Congress excludes both recoveries in their entirety. The value of this gift to $A$ in 2005, assuming no other income and no itemized deductions: $\$ 11,365$. The value of the gift to $B$ under the same assumptions: $\$ 520$. This difference is hard to justify. There is no reason to believe that the higher-income taxpayer $(A)$ needs or deserves over 20 times as large a governmental subsidy as the lower-income taxpayer $(B)$.

Recall, by contrast, that, except at lower income levels, Social Security Disability Insurance benefits are taxed in a manner consistent with both comprehensive tax base and ability-to-pay theory. This difference in treatment-taxing Social Security Disability Insurance benefits in a manner consistent with theory but excluding private disability insurance benefits completely-is arbitrary. A first-best abilityto-pay system would include all such benefits in income to the extent they exceed taxpayers' investments in their policies.

\section{Exclusion of Income Replacement Recoveries Received on Account of Personal Physical Injuries}

Section 104(a) (2) similarly excludes all damages received on account of personal physical injuries or physical sickness, ${ }^{279}$ including amounts intended to compensate tort plaintiffs for lost income. Assume, again, that a taxpayer is disabled in a traffic accident, but this time she is compensated for her lost income not by disability insurance but by the tortfeasor who injured her. Her lost income recovery will be completely tax-exempt, notwithstanding the fact that it replaces income which, if received in the ordinary course, would have been fully taxable. ${ }^{280}$ Indeed, under the tort laws of a majority of American jurisdictions, a taxpayer can recover her lost income twice: once from the tortfeasor and a second time from her disability insurance policy. ${ }^{281}$ Under current law, both are tax-exempt. A first-best ability-to-pay system would require all such recoveries to be includible.

${ }^{279}$ The statute provides for two exceptions irrelevant to the point made in the text. First, if a taxpayer recovers for amounts previously spent on medical expenses and deducted for that reason in a prior taxable year, the recovery of such amounts is includible. I.R.C. $\$ 104(\mathrm{a})$ (2000). Second, punitive damages are generally taxable even in cases involving personal physical injury. Id. § 104(a)(2). But see id. § 104(c) (excluding from income punitive damages in certain wrongful death actions).

${ }^{280}$ See supra note 183 and accompanying text.

281 See Stuart M. Speiser ET AL., The American Law of TORTS $\$ 8.16$ (1983 \& Supp. 2005) (discussing the application of the collateral source rule). 
With respect to amounts representing lost income, $\S 104(\mathrm{a})(2)$ is overgenerous and should be amended.

6. Credit for the Elderly and the Permanently and Totally Disabled

Section 22 provides further tax relief to two groups of taxpayers: (1) the elderly, and (2) taxpayers with disabilities. We will ignore the credit for the elderly and focus on the credit as it applies to the "disability income" of taxpayers with disabilities.

Section 22 creates a credit - that is, it reduces a taxpayer's regular tax liability dollar for dollar. If her pre-credit tax liability is $\$ 3,000$, for example, and she is entitled to a $\$ 2,500 \S 22$ credit, her post-credit tax liability will be only $\$ 500$. To qualify for the credit, a taxpayer must either have (1) attained the age of sixty-five before the close of the taxable year, or (2) retired on disability before the close of the taxable year at a time when she was permanently and totally disabled. ${ }^{282}$ An individual is permanently and totally disabled for this purpose if she is "unable to engage in any substantial gainful activity by reason of any medically determinable physical or mental impairment which can be expected to result in death or which has lasted or can be expected to last for a continuous period of not less than 12 months." 283 Participation in non-work activities may indicate that the person is not totally disabled. The fact that the taxpayer can take care of herself at home, engage in hobbies, receive institutional therapy or training, or participate in social activities, however, does not necessarily disqualify her.

Computation of the credit begins with what is called an "initial amount.” The initial amount is generally $\$ 5,000$ in the case of a single individual or a couple filing jointly where only one spouse is a qualified individual, $\$ 7,500$ in the case of a couple filing jointly where both spouses are qualified individuals, or $\$ 3,750$ in the case of a married individual filing a separate return. ${ }^{284}$ In the case of a taxpayer who has not yet reached the age of sixty-five, however, the initial amount cannot be greater than the taxpayer's includible "disability income." ${ }^{285}$ Disability income is defined as the taxable portion paid in lieu of wages for the period during which the taxpayer is absent from work because of permanent and total disability, but only if such amounts

\footnotetext{
${ }^{282}$ I.R.C. $\$ 22$ (b) (2000).

${ }^{283} I d . \S 22(\mathrm{e})(3)$.

${ }^{284} I d . \S 22(\mathrm{c})(2)(\mathrm{A})$

${ }^{285} I d . \S 22(\mathrm{c})(2)(\mathrm{B})(\mathrm{i})$.
} 
are (1) paid pursuant to an annuity, or (2) includible as health or accident insurance benefits if the taxpayer is an employee and either the premiums were paid by her employer on a tax-excludible basis or the benefits themselves are provided directly by the employer. ${ }^{286}$ As we have noted, disability insurance premiums are normally paid on an after-tax basis; this means that disability insurance benefits will normally not be taxable and will therefore not constitute qualifying "disability income" for $\S 22$ purposes. As a result, taxpayers with qualifying "disability income" are likely to be very rare. If a taxpayer is under sixtyfive and has no includible disability income, she will be ineligible for the credit. Assuming she is over sixty-five or has disability income, however, the computation continues.

From this initial amount, amounts received as pensions, annuities, or disability benefits are subtracted if and to the extent such amounts are either (1) excluded from income and payable under Title II of the Social Security Act, the Railroad Retirement Act of 1974, or any law administered by the Department of Veterans Affairs, or (2) excluded from income under a provision of law outside the Internal Revenue Code. ${ }^{287}$ For purposes of this Article, the most important subtraction is of the excludible portion of Social Security disability insurance benefits. A taxpayer who receives the 2003 average of $\$ 10,344$ per year $^{288}$ of excludible disability insurance benefits will therefore not be eligible for the credit at all, even if she is one of those rare taxpayers with qualifying "disability income." A taxpayer who receives taxable disability income but is ineligible for Social Security disability insurance benefits, however, may then claim the net amount (initial amount minus subtractions) as a credit against her regular tax liability-if she has any. As if this were not sufficiently limiting, the credit itself begins to phase out at extremely low income levels- $\$ 7,500$ for a single individual or $\$ 10,000$ for a couple filing jointly. ${ }^{289}$

With all these qualifications, the reader may suspect that this complicated credit is not worth very much. Indeed, the Treasury estimates that the credit as applied to both elderly and disabled taxpayers costs the federal government only $\$ 20$ million per year. ${ }^{290}$ The ag-

${ }^{286} I d . \S 22(\mathrm{c})(2)(\mathrm{B})(\mathrm{iii})$.

${ }^{287} I d . \S 22(\mathrm{c})(3)(\mathrm{A})$.

288 See ANNUAL STATISTICAL REPORT, supra note 20 (providing data on Social Security payments).

289 I.R.C. $\$ 22(d)(2000)$.

290 OfFice of MGMT. \& Budget, Budget of THE United StATES GOVERnMENT: ANALYTICAL PERSPECTIVES FisCAL YEAR 2007, at 289 tbl.19-1, line 149 (2006). 
gregate benefit to disabled taxpayers is only a portion of that $\$ 20$ million. That amounts to less than fifty cents per disabled American per year. In short, $\S 22$ appears to be a political makeweight and should probably be repealed.

\section{Additional Standard Deduction for the Blind}

Historically, the Code authorized two personal exemptions for taxpayers who were blind, instead of the single personal exemption permitted everyone else. This second personal exemption was added in part because of gratitude for the work of blind people in the defense industries during World War II and in part because Congress believed that it cost blind people more to live than people with sight. ${ }^{291}$ The second exemption caused significant resentment among people with other disabilities. In 1986, therefore, Congress converted the second exemption into an additional standard deduction-still limited, however, to people who were blind. ${ }^{292}$ For 2005, the additional standard deduction for the elderly and the blind, which now appears in $\S 63(\mathrm{f})(2)$, was $\$ 1,000$ each for married individuals and surviving spouses and $\$ 1,250$ for all others. ${ }^{293}$

By converting the second personal exemption into an additional standard deduction, Congress exacerbated the anomalous effects of the standard deduction for people who are blind. The additional standard deduction makes it less likely that a blind person will be able to deduct medical expenses or any employment-related expenses, for example. For a blind person with significant below-the-line deductions, the additional standard deduction is therefore useless. Clearly the conversion saved the Treasury revenue, but whether it accomplished anything else is unclear.

Today's additional standard deduction helps blind taxpayers without significant itemized deductions, but is of no assistance to people with other disabilities, even those with greater living expenses. It is true that some who are blind have significant extra working and liv-

291 MENDELSOHN, supra note 5, at 225-26.

${ }^{292}$ For this purpose, blindness is defined by reference to measured visual acuity: [A] $\mathrm{n}$ individual is blind only if his central visual acuity does not exceed $20 / 200$ in the better eye with correcting lenses, or if his visual acuity is greater than $20 / 200$ but is accompanied by a limitation in the fields of vision such that the widest diameter of the visual field subtends an angle no greater than 20 degrees. I.R.C. $§ 63$ (f) (4) (2000).

${ }^{293}$ Rev. Proc. 2004-71, 2004-50 I.R.B. 970, 973-74. 
ing expenses, such as a driver, a guide dog, or a reader. Others, however, have few additional expenses; they use public transportation and/or a cane and read Braille fluently. People with other disabilities may have substantially greater living and working costs by reason of their disabilities; a person who is a quadriplegic, for example, may have significant needs for home care, transportation, and medical expenses, among others. Such other people with disabilities receive no additional personal exemption or standard deduction. In short, the additional standard deduction for blind taxpayers appears to reflect Justice Frankfurter's aphorism in Kaiser that "the blind are a common object of charity," ${ }^{294}$ and little more. It treats all people with blindness the same and treats them all as generically more deserving than other people with disabilities.

The additional standard deduction for the blind also places disability advocates between a rock and a hard place: it is offensive, discriminatory, often useless, and makes the income tax system even more incoherent for those it benefits, but it does help some people with disabilities. In our view, an above-the-line deduction for the actual special costs of disability-not just blindness-would be far preferable. We discuss the extent to which the deduction for medical expenses approximates this ideal, and how it might be improved, in Part III.C. 2 below.

\section{B. Provisions Consistent with the Civil Rights Model of Disability}

A variety of largely minor Code provisions affecting people with disabilities are consistent with the more recent civil rights model of disability.

\section{Incentives for Businesses To Comply with Disability Statutes}

In connection with the Americans with Disabilities Act (ADA), the "disabled access credit" was enacted in 1990 to assist small businesses in complying with that Act. Section 44 allows an "eligible small business" to claim a credit against taxes equal to $50 \%$ of the business's "eligible access expenditures" over $\$ 250$ but under $\$ 10,250$. $^{295}$ The maximum allowable credit per taxpayer, therefore, is approximately $\$ 5,000$ per year. The credit is limited to businesses with annual gross receipts of less than $\$ 1$ million or fewer than thirty full-time employ-

\footnotetext{
${ }^{294}$ United States v. Kaiser, 363 U.S. 299, 314 (1960) (Frankfurter, J., concurring).

${ }^{295}$ I.R.C. $\S 44(\mathrm{a})(2000)$.
} 
ees. ${ }^{296}$ "Eligible access expenditures" consist of amounts paid or incurred "to comply with applicable requirements under the Americans With Disabilities Act of 1990 (as in effect on the date of the enactment of this section)." ${ }^{297}$ In other words, small businesses may reduce their federal income taxes by fifty cents for every dollar spent complying with the accommodation requirements of the ADA over $\$ 250$ but under $\$ 10,250$ each year.

Similarly, in connection with the Rehabilitation Act of 1973, the "barrier removal deduction" was enacted in 1976 to help businesses comply with that Act. ${ }^{298}$ Normally, costs of improvements to real property used in the production of income must be capitalized; they may not be deducted currently. Section 190, however, authorizes businesses to deduct up to $\$ 15,000$ of qualified "architectural and transportation barrier removal expenses" on a current basis each year. ${ }^{299}$ For purposes of this section, an "architectural and transportation barrier removal expense" means "an expenditure for the purpose of making any facility or public transportation vehicle owned or leased by the taxpayer for use in connection with his trade or business more accessible to, and usable by, handicapped and elderly individuals." 300 "Handicapped individual," in turn, is defined, consistent with the Rehabilitation Act, as "any individual who has a physical or mental disability... which for such individual constitutes or results in a func-

${ }^{296}$ Id. $\S 44(\mathrm{~b})(1)$.

${ }^{297}$ Creditable amounts include amounts paid or incurred:

(A) for the purpose of removing architectural, communication, physical, or transportation barriers which prevent a business from being accessible to, or usable by, individuals with disabilities,

(B) to provide qualified interpreters or other effective methods of making aurally delivered materials available to individuals with hearing impairments,

(C) to provide qualified readers, taped texts, and other effective methods of making visually delivered materials available to individuals with visual impairments,

(D) to acquire or modify equipment or devices for individuals with disabilities, or

(E) to provide other similar services, modifications, materials, or equipment. Id. $\S 44(\mathrm{c})(2)$.

Id. $\$ 190$

${ }^{299} I d . \S 190(\mathrm{a})(1)$.

${ }^{300} I d . \S 190$ (b) (1). A "facility" is defined as "all or any portion of buildings, structures, equipment, roads, walks, [or] parking lots.” 26 C.F.R. § 1.190-2(a)(1) (2005). "Public transportation vehicles" are vehicles that provide transportation services to the public, such as a bus or train. Id. $\S 1.190-2$ (a) (2). Examples of qualified expenses would be the construction costs of a ramp to replace stairs and modification costs on a vehicle to transport business customers. Id. 
tional limitation to employment, or who has any physical or mental impairment ... which substantially limits one or more major life activities of such individual." ${ }^{301}$

In 2002, the General Accounting Office issued a report assessing the effectiveness of these incentives. ${ }^{302}$ In 1999, it observed, some $\$ 59$ million of disabled access credits were claimed; only 1 out of every 686 corporations and 1 out of every 1570 individuals with a business affiliation claimed such credits that year. ${ }^{303}$ Comparable information was not available with respect to the barrier removal deduction. The GAO stated:

Many of the business representatives and others we spoke with were either unaware of these incentives or did not have an opinion about their effectiveness. Of those with an opinion, the barrier removal deduction was viewed by more individuals as having a positive effect. ... [T] hey believed that the barrier removal deduction was more widely used because larger businesses, that are more likely to be aware of and willing to use tax incentives, are eligible for this incentive. However, . . . use of the deduction was limited because it only allows specific types of architectural and transportation modifications. Implemented more than 20 years ago, the deduction cannot be applied to the cost of addressing communication and electronic barriers in today's modern workplace. ${ }^{304}$

The disabled access credit and barrier removal deduction are clearly subsidies authorized for nontax reasons and delivered through the tax system. The GAO found no studies assessing the effectiveness of these subsidies. ${ }^{305}$ In the absence of such studies, it is difficult to take any position with respect to whether these provisions are worth their cost.

301 I.R.C. $\$ 190$ (b) (3).

302 U.S. GEN. ACCOUnting OfFice, Business TAX InCENTIVES: InCENTIVES TO EMPLOY WORKERS WITH DISABILITIES RECEIVE LIMITED USE AND HAVE AN UNCERTAIN IMPACT, GAO-03-39, at 4-6 (2002), available at http://www.gao.gov/new.items/ d0339.pdf. The report also assessed the effectiveness of the "work opportunity tax credit" of $\$ 51$, which allows a credit for part of the first-year wages of certain economically disadvantaged workers, including workers with disabilities who received specified rehabilitation services or SSI benefits. Id. at 11-14. The credit does not apply to any individual who commences employment after December 31, 2001. I.R.C. $\S$ $51(\mathrm{c})(4)(\mathrm{B})$.

${ }^{303}$ U.S. GEN. ACCOUNTING OFFICE, supra note 302, at $14 \mathrm{nn} .27-28$.

${ }^{304}$ Id. at 19.

${ }^{305} \mathrm{Id}$ 


\section{Above-the-Line Deduction for Attorney's Fees in Civil Rights Actions}

Prior to the enactment of the American Jobs Creation Act $^{306}$ in October 2004, a majority of the U.S. courts of appeals held that attorney's fees awarded to plaintiffs should be included in plaintiffs' income and deducted below-the-line as costs of producing income. ${ }^{307}$ Below-the-line deductions, however, were not deductible for alternative minimum tax purposes. This, in turn, meant that plaintiffs were potentially subject to the alternative minimum tax on the gross amount of their awards-not on their net economic income. ${ }^{308}$

To solve this problem, Congress added $\S 62$ (a) (20), which defines as above-the-line, inter alia, "[a]ny deduction allowable . . . for attorney fees and court costs paid by, or on behalf of, the taxpayer in connection with any action involving a claim of unlawful discrimination ...." ${ }^{309}$ As a result, plaintiffs asserting disability discrimination claims will hereafter be subject to tax on no more than their economic income from such recoveries, consistent with comprehensive tax base theory and ability to pay.

\section{Provisions Consistent with the Human Variation Model of Disability}

A first-best ability-to-pay tax system would allow deduction of unusual nondiscretionary expenses that diminish ability to pay. Such

${ }^{306}$ Pub. L. No. 108-357, 118 Stat. 1418 (2004).

307 See Leah Witcher Jackson, Won the Legal Battle, but at What Tax Cost to Your Client: Tax Consequences of Contingency Fee Arrangements Leading up to and After Commissioner v. Banks, 57 BAYLOR L. REV. 47, 69-79 (2005) (discussing circuit decisions concerning whether the plaintiff or her attorney need include attorney's fees as gross income); Jennifer S. Neumann, Comment, The Discrimination Created by the Tax Treatment of Attorney's Fees in Federal Civil Rights Cases, 51 U. KAN. L. REv. 595, 599 (2003) ("The majority of courts have ruled that plaintiffs must include their attorney's fees . . in their gross income."). The correctness of the majority view prior to enactment of the American Jobs Creation Act was subsequently confirmed by the Supreme Court in Commissioner $v$. Banks, 543 U.S. 426 (2005)

${ }^{308}$ See, e.g., Jackson, supra note 307, at 105-13 (discussing the legal and policy arguments for excluding contingency fees from taxable income); Edward A. Morse, Taxing Plaintiffs: A Look at Tax Accounting for Attorney's Fees and Litigation Costs, 107 DICK. L. REV. 405, 424-31 (2003) (discussing the impact of the alternative minimum tax deduction limits on both low- and high-income clients); Gregg D. Polsky \& Stephen F. Befort, Employment Discrimination Remedies and Tax Gross Ups, 90 IOWA L. REv. 67, 79 (2004) ("In [some] cases, the AMT trap turns an apparent pre-tax 'winner' into an after-tax 'loser' ... .”); Laura Sager \& Stephen Cohen, How the Income Tax Undermines Civil Rights Law, 73 S. CAL. L. REv. 1075, 1077-78 (2000) (arguing for allowing deductions for attorney's fees for alternative minimum tax purposes).

${ }^{309}$ I.R.C. $§ 62$ (a) (20) (West Supp. 2005). 
deduction would be allowed in addition to a standard deduction whose function would be to define part of an initial exempt amount and therefore, in current terms, would be above the line. In the disability context, such an arrangement would be fully consistent with a human variation model of disability - that is, it would not give people with disabilities special breaks for charitable reasons but would rather impose a uniform ability-to-pay tax in ways that take human variation, including various forms of disability, into account. Two provisions of current law are moving the U.S. income tax system towards this ideal: the exemption of impairment-related work expenses from the $2 \%$ floor on miscellaneous itemized deductions ${ }^{310}$ and the medical expense deduction. ${ }^{311}$ Each could use some tweaking to move it closer to this ideal. Two further provisions-the credit for household and dependent care services ${ }^{312}$ and the exclusion for employer-provided dependent care assistance ${ }^{313}$-appear at first glance to perform similar functions; on closer examination, however, they turn out to have very different purposes.

1. Exemption of Impairment-Related Work Expenses from the 2\% Floor on Miscellaneous Itemized Deductions

As we have noted, $§ 67$ imposes a $2 \%$ floor on "miscellaneous deductions," as a result of which taxpayers can claim such deductions only to the extent they exceed $2 \%$ of adjusted gross income. ${ }^{314}$ Since the work-related expenses of employees fall into the "miscellaneous deduction" category, ${ }^{315}$ this has the effect of mismeasuring the income of employees with work-related expenses. Section 67(b) (6), however, exempts "impairment-related work expenses" from the operation of this floor. For this purpose, "impairment-related work expenses" are defined as "expenses ... of a handicapped individual . . . for attendant care services at the individual's place of employment and other expenses in connection with such place of employment which are necessary for such individual to be able to work, and with respect to which a deduction is allowable under section $162 \ldots$..."316 "Handicapped indi-

${ }^{310}$ I.R.C. $\$ 67(b)(6)(2000)$.

${ }^{311} I d . \S 213$.

${ }^{312} I d . \$ 21(\mathrm{a})$.

313 Id. $\$ 129$.

${ }^{314} I d . \$ 67(\mathrm{a})$.

${ }^{315}$ See id. $\$ 67$ (b) (failing to include work-related expenses among the list of exempted deductions).

${ }^{316} I d . \S 67(\mathrm{~d})$. 
vidual" is defined by cross-reference to $\S 190,{ }^{317}$ and therefore in a manner consistent with the Rehabilitation Act.

The exemption itself is consistent with comprehensive tax base theory, an ability-to-pay tax system, and the human variation paradigm. It is also consistent with the civil rights paradigm as implemented in the Americans with Disabilities Act. As a result of the exemption, people with disabilities are more likely to be able to deduct the extra costs they incur to earn a living. This more correctly measures their economic income for comprehensive tax base purposes, adjusts for ability to pay, and does so without granting people with disabilities a charitable preference. People with disabilities, like their non-disabled peers, are equally subject to the $2 \%$ floor with respect to ordinary employment-related costs like union dues. Finally, the exemption facilitates the reintegration of people with disabilities into the societal mainstream, as envisioned by the Americans with Disabilities Act. In effect, it renders it more likely that such taxpayers will be able to deduct accommodations required to enable them to work when they themselves pay for such accommodations.

The practical effects of $\S 67$ (b) (6), however, are modest. The section does not change the Code's characterization of such costs as below-the-line deductions, nor does it make those costs deductible for alternative minimum tax purposes. It is therefore only a beginning; its beneficial effects may easily be thwarted by the incoherence of the mechanical structure of the Code as a whole. In a first-best ability-topay system, all costs of producing income would be deductible in addition to, not in place of, the standard deduction for regular tax purposes and would be fully deductible for alternative minimum tax purposes (if any such tax continued to exist).

\section{Medical Expense Deduction}

Section 213 allows a deduction for expenses for "medical care of the taxpayer, his spouse, or a dependent... to the extent that such expenses exceed 7.5 percent of adjusted gross income." 318 "Medical care" originally referred only to amounts paid for the "diagnosis, cure, mitigation, treatment, or prevention of disease, or for the purpose of affecting any structure or function of the body. ..." 319 We commonly think of $\S 213$ as authorizing deduction of the costs of services pro-

\footnotetext{
${ }^{317} I d . \S 67(\mathrm{~d})(1)$; see also supra note 301 and accompanying text.

${ }^{318}$ I.R.C. $\$ 213(\mathrm{a})$.

319 Id. $\S 213(\mathrm{~d})(1)(\mathrm{A})$.
} 
vided by medically trained personnel, plus incidental expenses like drugs, eyeglasses, or crutches. In a development largely overlooked by tax scholars over the past half century, ${ }^{320}$ however, administrative interpretations and Congressional amendments have expanded the deduction to cover many of the extra costs that people with disabilities incur in the course of everyday life. Today it might more properly be referred to as the "medical and disability expense deduction." In effect, for people with disabilities, this change has converted the U.S. income tax into a tax based on ability to pay.

The transformation began in the late 1950s. In Revenue Ruling 55-261, when construing the predecessor to $\S 213$, the IRS gave the term "medical care" a narrow interpretation, disallowing the costs of a wheelchair to a totally disabled veteran on the ground that "transportation" was personal, not incurred primarily for the alleviation of a physical defect or illness. ${ }^{321}$ The ruling similarly denied the deduction of the special costs of transportation to and from a taxpayer's place of employment when necessitated by the taxpayer's disability, again on the ground that such costs were personal. ${ }^{322}$ In this latter regard, the ruling cited Bruton v. Commissioner ${ }^{323}$ and Ranstead v. Commissioner, ${ }^{324}$ which had held, based on regulations issued under the predecessor to $\S 162$, that commuting expenses were personal. Three years later, in Revenue Ruling 58-8, the IRS began to reverse course, holding that the cost of a wheelchair used "primarily for the alleviation of his sickness or disability, and not merely to provide transportation between his residence and place of employment" was a deductible medical expense. $^{325}$

Although the IRS did not so state, at issue was the meaning of the phrase "mitigation... of disease" in the definition of deductible "medical care." Read narrowly, that phrase might be limited to efforts to make a disease milder-much as, for example, insulin can be used to manage diabetes without curing it. Read more broadly, however, the phrase might include efforts to alleviate the impact of the disease on the victim's life-including her day-to-day personal activities. Thus, a wheelchair could be seen as reducing the impact of paralysis, thereby mitigating it, even though the purpose of the wheelchair was

${ }^{320}$ See, e.g., Colliton, supra note 110, at 1329-33 (not discussing this development).

${ }^{321}$ 1955-1 C.B. 307, 311.

${ }^{322}$ Id. at 309.

${ }^{323} 9$ T.C. 882 (1947).

32410 T.C.M. (CCH) 117 (1951).

${ }^{325}$ 1958-1 C.B. $154,155$. 
to permit transportation, a personal activity. The extra cost of a closed-caption television set (before closed-captioning was widely available) could be seen as reducing the impact of deafness, even though the purpose of the television set itself was entertainment, a personal activity. ${ }^{326}$ Amounts paid to have someone accompany a blind child throughout the school day could be seen as reducing the impact of blindness, even though the purpose was to facilitate education, again, a clearly personal activity. ${ }^{327}$ Over the past half century, in these and other contexts, the IRS has adopted this broader meaning of the statute. ${ }^{328}$ Today, the extra costs of enabling a person with disabilities to engage in ordinary activities notwithstanding her disability are generally deductible, even if those activities are "personal." The one major exception remains the extra cost of commuting to work, to which we return shortly.

A similar shift has occurred in the deductibility of household services, primarily as a result of congressional action. In a series of court cases $^{329}$ culminating in Revenue Ruling $76-106,{ }^{330}$ the IRS maintained, for the most part successfully, that

${ }^{326}$ See Rev. Rul. 80-340, 1980-2 C.B. 81, 82 (allowing such a deduction).

${ }^{327}$ Rev. Rul. 64-173, 1964-1 C.B. 121, 122.

${ }^{328}$ See, e.g., Rev. Rul. 75-318, 1975-2 C.B. 88, 88 (allowing deduction of the cost of Braille books and magazines to the extent such cost exceeds the cost of regular printed editions); Rev. Rul. 71-48, 1971-1 C.B. 99, 99, amplified by Rev. Rul. 73-53, 1973-1 C.B. 139 (stating that the cost of a text telephone that enables a deaf taxpayer to communicate by telephone is deductible as a medical expense); Rev. Rul. 70-606, 1970-2 C.B. 66, 66 (ruling that the amount paid for an automobile specially designed for transporting individuals confined to wheelchairs, which amount is attributable to its special design, is deductible as a medical expense); Rev. Rul. 58-223, 1958-1 C.B. 156, 156 (holding that costs of special aids to assist in education of a child becoming blind, such as tape recorder, special typewriter, projection lamp for enlarging written material, and special lenses, are to mitigate the condition of losing sight and therefore deductible as medical expenses); Rev. Rul. 55-261, 1955-1 C.B. 307, 308, modified by Rev. Rul. 58-8, 1958-1 C.B. 154, Rev. Rul. 58-280, 1958-1 C.B. 157, Rev. Rul. 63-91, 1963-1 C.B. 54, and Rev. Rul. 68-212, 1968-1 C.B. 91 (allowing costs of a seeing-eye dog to be deductible as medical expenses).

${ }^{329}$ See, e.g., McVicker v. United States, 194 F. Supp. 607, 608 (S.D. Cal. 1961) (refusing to allow a deduction for a "domestic servant"); Van Vechten v. Comm'r, 32 T.C.M. (CCH) 1363, 1365 (1973) (holding that a household employee was not a valid medical expense and therefore not deductible); Bye v. Comm'r, 31 T.C.M. (CCH) 238, 240 (1972) ("Domestic services performed in a home to permit an ill household member to have complete rest are not medical care; however, expenses attributable to services rendered directly to such household member which are of the type that would otherwise be performed in a hospital qualify as medical expenses.”).

${ }^{330}$ 1976-1 C.B. 71. 
household and other personal services are nonmedical services, payments for which are nondeductible under section $262 . \ldots$ Thus, an apportionment must be made as between the time spent by the attendant in performing nursing-type services, and the time spent performing household and other personal services. The portion of the attendant's wages allocable to the nursing-type services is deductible by the taxpayer as medical expenses within the limitations of section 213. The portion of the wages allocable to household and other personal services is nondeductible under section 262 . $^{331}$

The ruling in question involved a quadriplegic taxpayer who had undergone an ileostomy and was forced to hire an attendant to help care for the resulting condition and with dressing, grooming, bathing, cooking, and cleaning. The ruling held that the dressing, grooming, and bathing were deductible "nursing-type services," but that the cooking and cleaning were not. ${ }^{332}$

Then in 1996, the Health Insurance Portability and Accountability Act (HIPAA) expanded the definition of "medical care" $" 333$ to include "qualified long-term care services," defined in $\S 7702 \mathrm{~B}$ to mean: "necessary diagnostic, preventive, therapeutic, curing, treating, mitigating, and rehabilitative services, and maintenance or personal care services, which (A) are required by a chronically ill individual, and (B) are provided pursuant to a plan of care prescribed by a licensed health care practitioner." ${ }^{334}$ Of particular significance was the inclusion of "maintenance or personal care services" for "chronically ill individuals." "Chronically ill individual" was defined, inter alia, to mean

any individual who has been certified by a licensed health care practitioner as (i) being unable to perform (without substantial assistance from another individual) at least 2 activities of daily living for a period of at least 90 days due to a loss of functional capacity... or (iii) requiring substantial supervision to protect such individual from threats to health and safety due to severe cognitive impairment. ${ }^{335}$

${ }^{331} I d$. at 72 .

${ }^{332} I d$.

333 "Medical care" is now defined as amounts incurred:

(A) for the diagnosis, cure, mitigation, treatment, or prevention of disease, or for the purpose of affecting any structure or function of the body,

(B) for transportation primarily for and essential to medical care referred to in subparagraph (A),

(C) for qualified long-term care services ...., and

(D) for insurance . . . covering medical care ... .

I.R.C. $\S 213(\mathrm{~d})(1)(2000)$.

Id. $\$ 7702 \mathrm{~B}(\mathrm{c})(1)$.

${ }^{335} I d . \$ 7702 \mathrm{~B}(\mathrm{c})(2)(\mathrm{A})$. 
The relevant "activities of daily living" included eating, toileting, transferring from one activity to another, bathing, dressing, and continence. "Maintenance or personal care services" were defined to include "any care the primary purpose of which is the provision of needed assistance with any of the disabilities as a result of which the individual is a chronically ill individual . . .."337

It is unclear how much of Revenue Ruling 76-106 survived this amendment. Cooking, for example, is normally a prerequisite to eating, an included "activity of daily living" under HIPAA; washing the dishes normally follows. If an attendant cooks a meal for a chronically ill individual prior to feeding her and then washes the dishes afterwards, it would seem odd for the feeding but not the cooking or cleaning-up to constitute "maintenance or personal care services" within the meaning of the statute. To date, the IRS has issued no formal guidance on the scope of deductible "maintenance or personal care services." In Publication 502, it reconciles its ruling position with HIPAA in the following not-very-helpful terms:

Generally, only the amount spent for nursing services is a medical expense. If the attendant also provides personal and household services, amounts paid to the attendant must be divided between the time spent performing household and personal services and the time spent for nursing services. However, certain maintenance or personal care services provided for qualified long-term care can be included in medical expenses. $^{338}$

Clearly, for taxpayers who are not "chronically ill individuals," Revenue Ruling 76-106 remains in force. Where the attendant also provides services for family members of the "chronically ill individual," we expect the ruling to continue to disallow deduction of such services. We question, however, whether any administrable construction of that ruling remains possible with respect to household services provided to individuals eligible for qualified long-term care services. With respect to such individuals, the Association of Health Insurance Advisors gives the phrase qualified "long-term care services" an effectively unlimited construction: "all the assistance you could need if you ever

${ }^{336} I d . \S 7702 \mathrm{~B}(\mathrm{c})(2)(\mathrm{B})(\mathrm{i})-(\mathrm{vi})$.

${ }^{337}$ Id. $\$ 7702 \mathrm{~B}(\mathrm{c})(3)$.

${ }^{338}$ I.R.S. Publication 502: Medical and Dental Expenses 11 (2005), available at http://www.irs.gov/pub/irs-pdf/p502.pdf; see also id. at 14 (excluding from claimed medical expenses "the cost of household help, even if such help is recommended by a doctor" and noting that such expenses are personal and not deductible unless they are "paid to a person providing nursing-type services" or "certain maintenance or personal care services provided for qualified long-term care"). 
have a chronic illness or disability that leaves you unable to care for yourself for an extended period of time." 339

In any event, the effect of HIPAA and the Service's expanded interpretations of $\S 213$ has been to render a large portion of the unusual expenses people with disabilities routinely incur to engage in everyday activities deductible as medical expenses. According to Publication 502, deductible medical expenses now include the costs of artificial limbs, ${ }^{340}$ Braille books and magazines in excess of the costs of regular printed editions, ${ }^{341}$ improving a home for medical reasons to the extent such improvements do not increase its value (for example, constructing ramps, widening doors and hallways, installing railings or support bars, lowering kitchen cabinets and equipment, or installing porch lifts), ${ }^{342}$ special hand controls and other special equipment installed in a car for use by a person with a disability, ${ }^{343}$ some disabled dependent care ${ }^{344}$ a guide $\operatorname{dog},{ }^{345}$ a hearing aid, ${ }^{346}$ qualified long-term care services, ${ }^{347}$ special telephone equipment, ${ }^{348}$ special closedcaptioning equipment for televisions, ${ }^{349}$ and wheelchairs. ${ }^{350}$ In addition, the excess cost of any item purchased in special form to "alleviate a physical defect," where the item is one that in normal form is used for "personal, living, or family purposes," is also deductible as a medical expense. ${ }^{351}$

As a practical matter, the most important nondeductible unusual expenses still facing taxpayers with disabilities are the special costs of transportation to and from work ${ }^{352}$ and household help ${ }^{353}$ for taxpayers who do not qualify as "chronically ill individuals." The nondeductibility of unusual commuting expenses under $\S 213$ was estab-

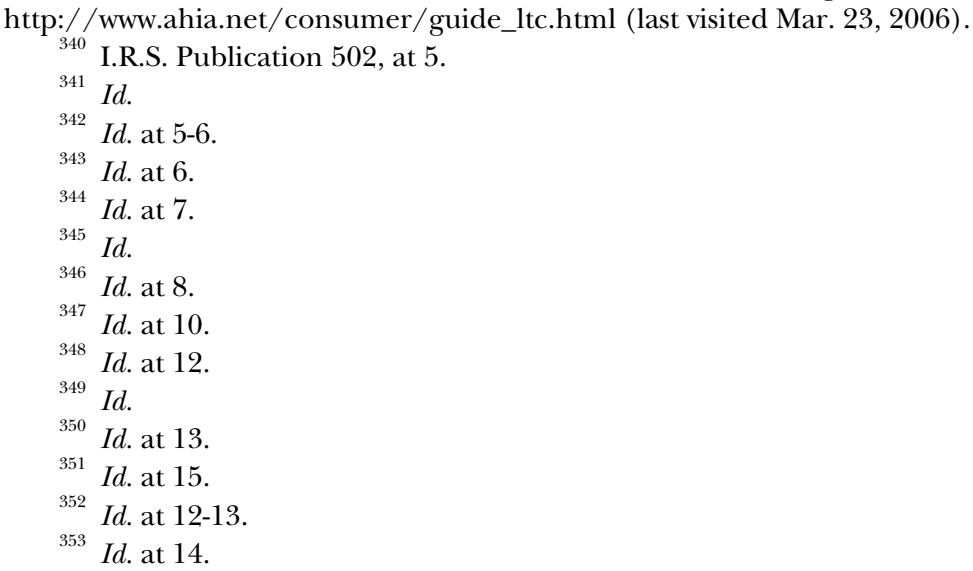


lished in Bruton v. Commissioner ${ }^{354}$ and Ranstead v. Commissioner ${ }^{355}$ before the modern expansive interpretation of $\S 213$. We doubt those cases would have been decided the same way today and believe they should be overruled or abandoned by the IRS. It is anomalous to permit people with disabilities to deduct the extra costs of reading or watching television at home and the extra costs of earning a living once at work, but not the extra costs of getting to work. It is also fundamentally inconsistent with the philosophy of the ADA.

The problem of household help for taxpayers who do not qualify as "chronically ill individuals" is more difficult. We do not know how large the problem is. We also recognize the potential for abuse reflected in early cases disallowing deduction of such expenses. Further work on this issue may be warranted.

3. Credit for Household and Dependent Care Services and Exclusion of Employer-Provided Dependent Care Assistance

The exemption of impairment-related work expenses from the $2 \%$ floor addresses the problem of extra expenses incurred by people with disabilities while working. The medical expense deduction deals with extra expenses incurred by people with disabilities in the course of everyday activities. Extra expenses incurred by a household member for care of a person with disabilities to enable the non-disabled household member to work are addressed by $\S \S 21$ and 129, which might therefore appear to represent part of Congress's effort to measure ability to pay in the disability context.

Deductibility of expenses for the care of disabled dependents was historically linked to the deductibility of expenses for the care of minor children. The latter issue was first raised in 1939 in Smith v. Commissioner, when the Board of Tax Appeals held that the expenses of hiring someone to care for a taxpayer's young children while she went to work were personal and therefore not deductible as business expenses. ${ }^{356}$ The 1954 Tax Code responded by introducing a deduction for child-care expenses of up to $\$ 600 .^{357}$ The Tax Reform Act of 1976 then repealed the deduction and substituted the $\S 44 \mathrm{~A}$ (now $\S 21$ ) credit for expenses for household and dependent care services necessary for gainful employment.

\footnotetext{
${ }^{354} 9$ T.C. 882,886 (1947).

35510 T.C.M. 117,117 (1951).

35640 B.T.A. $1038,1039-40$ (1939).

${ }^{357}$ I.R.C. $\$ 214$ (repealed 1976).
} 
Section 21 authorizes a credit against the tax liability of any taxpayer who maintains a household including one or more "qualifying individuals" in an amount equal to the "applicable percentage" of that taxpayer's "employment-related expenses." The portion of the definition of "qualifying individual" relevant to this Article reads as follows: "(B) a dependent of the taxpayer who is physically or mentally incapable of caring for himself, or $(\mathrm{C})$ the spouse of the taxpayer, if the spouse is physically or mentally incapable of caring for himself." ${ }^{358}$

The regulatory definition of physical or mental incapacity tracks, in more archaic language, the definition of "chronically ill individual" in $\S 7702 \mathrm{~B}$, discussed above in connection with the medical expense deduction:

An individual is considered to be physically or mentally incapable of selfcare if as a result of a physical or mental defect the individual is incapable of caring for his or her hygienical or nutritional needs, or requires full-time attention of another person for his or her own safety or the safety of others.... An individual who is physically handicapped or is mentally defective, and for such reason requires constant attention of another person, is considered to be physically or mentally incapable of self-care. $^{359}$

The "applicable percentage" equals 35\%, reduced, but not below $20 \%$, by one percentage point for each $\$ 2,000$ by which taxpayer's adjusted gross income exceeds $\$ 15,000$.

Finally, "employment-related expenses" means expenses for household services or for the care of a qualifying individual, but only if they are incurred to enable the taxpayer to be gainfully employed. "Household services" are defined by regulation as follows:

Expenses are considered to be paid for household services if they are paid for the performance in and about the taxpayer's home of ordinary and usual services necessary to the maintenance of the household. However, expenses are not considered as paid for household services unless the expenses are attributable in part to the care of the qualifying individual. Thus, amounts paid for the services of a domestic maid or cook are considered to be expenses paid for household services if a part of those services is provided to the qualifying individual. Amounts paid for the services of an individual who is employed as a chauffeur, bartender, or gardener, however, are not considered to be expenses paid for household services. ${ }^{360}$

\footnotetext{
${ }^{358}$ I.R.C. $§ 21(\mathrm{~b})(1)(2000)$.

359 Treas. Reg. § 1.44A-1 (b) (4) (2003).

${ }^{360} I d . \S 1.44 \mathrm{~A}-1$ (c) (2).
} 
"Expenses for the care of a qualifying individual," in turn, are defined in the following terms:

The primary purpose of expenses for the care of a qualifying individual must be to assure that individual's well-being and protection.... [A]mounts paid to provide food, clothing, or education are not expenses paid for the care of a qualifying individual. However, where the manner of providing care is such that the expense which is incurred includes expenses for other benefits which are incident to and inseparably a part of the care, the full amount of the expense is considered to be incurred for care.

Employment-related expenses are capped at $\$ 3,000$ for one qualifying individual or $\$ 6,000$ for two or more qualifying individuals, reduced by amounts paid or incurred by the taxpayer's employer for dependent care assistance, excludible under $\S 129$ as discussed below. ${ }^{362}$ They are further limited, in general, to the amount of the taxpayer's earned income. ${ }^{363}$

The net effect of all these rules is to authorize a credit of up to $\$ 1,050$ for one qualifying individual or $\$ 2,100$ for two or more qualifying individuals if the taxpayer's adjusted gross income is no greater than $\$ 15,000$, or of up to $\$ 600$ for one qualifying individual or $\$ 1,200$ for two qualifying individuals if the taxpayer's adjusted gross income equals or exceeds $\$ 45,000$.

Section 129, in turn, excludes amounts paid or incurred by an employer for dependent care assistance provided to the employee. For this purpose, dependent care assistance is defined by reference to $\S 21 .^{364}$ The $\S 129$ exclusion is limited to $\$ 5,000$ for a single taxpayer or a married taxpayer filing jointly or to $\$ 2,500$ in the case of a married taxpayer filing separately. ${ }^{365}$ An earned income limitation similar to that of $\S 21$ is also imposed. ${ }^{36}$

Where the qualifying individual is a person with a disability, the relationship between the $\S 21$ credit for household and dependent care services and the $\$ 213$ deduction for medical expenses is unclear. Presumably, one cannot claim both for the same expenses, although the Code nowhere so provides. The definitions of household and dependent care services for credit purposes may provide useful guidance

${ }^{361} I d . \S 1.44 \mathrm{~A}-1$ (c) (3).

${ }^{362}$ I.R.C. $\$ 21(\mathrm{c})(2000$ \& Supp. 2001).

${ }^{363}$ I.R.C. $\$ 21(\mathrm{~d})(1)(2000)$.

${ }^{364} I d . \S 129(\mathrm{e})(1)$.

${ }^{365}$ Id. $\$ 129$ (a) (2) (A).

${ }^{366}$ Id. $\$ 129$ (b) (1). 
in construing "maintenance and personal care services" under HIPAA, and vice versa.

Now that HIPAA permits deduction of expenses for "maintenance and personal care services" as "medical expenses," however, one might reasonably ask why allowance of a credit for household and dependent care services where the qualifying individual is a person with a disability is justified at all. The answer is simple: the stated purposes of $\S \S 21$ and 129 were not to measure ability to pay. They were rather to provide "a substantial work incentive for families with children ... directed particularly toward low- and middle-income taxpayers" and "incentives for employers to become more involved in the provision of dependent care for their employees." 367 Whether such purposes are worthy raises issues beyond the scope of this Article. Notwithstanding their relevance to persons with disabilities, therefore, we express no view whether they should be retained.

\section{Proposals FOR CHANGE}

We have used ability to pay as the organizing theme of this Article because we believe it most closely captures the popular moral intuitions that underlie provisions of particular relevance to people with disabilities and, indeed, significant features of the individual income tax system itself. Explicit consideration of ability to pay also allows the tax system to take individual differences into account. Not all taxpayers with equal incomes have equal abilities to pay taxes. A tax system structured to take into account only the needs and abilities of the "normal" majority is no more fair or just than a courthouse or other public facility built solely to accommodate the physical needs and abilities of that majority.

We acknowledge that ability-to-pay analysis is outside the mainstream of current tax scholarly thinking. As we have noted, contemporary tax scholarship is based primarily on utilitarian normative foundations and assumes, for the most part, that all taxpayers are identical in needs and abilities. In recent years, this has led many tax theorists to endorse conversion of the individual income tax into a tax

${ }^{367}$ STAFF OF J. COMM. ON TAXATION, GENERAL EXPLANATION OF THE ECONOMIC Recovery TAX ACT OF 1981, at 53-54 (Comm. Print 1981). 
on consumption ${ }^{368}$-effectively an income tax in which amounts saved are excluded from taxation and amounts borrowed are taxable.

We do not believe that such a tax would be normatively stablethat is, we do not believe that such a tax would be acceptable to the electorate in the long run. A simple example illustrates our problem. Assume that Ebenezer Scrooge earns $\$ 1$ million per year but spends only $\$ 10,000$-in other words, his income is $\$ 1$ million but his consumption is only $\$ 10,000$. Bob Cratchett, by contrast, earns $\$ 20,000$ per year, of which he spends $\$ 10,000$ on nondiscretionary medical and other unusual expenses required by the disability of his child, Tiny Tim, and the remaining $\$ 10,000$ on the other costs of maintaining himself and his family. Cratchett therefore "consumes" $\$ 20,000$ per year; Scrooge only $\$ 10,000$. Under a consumption tax, Cratchett should pay roughly twice as much tax as Scrooge-more if consumption is taxed progressively. Such a result would be inconsistent with our values and, we believe, the values of a vast majority of the electorate, as expressed over almost a century of U.S. tax history.

For this reason, we have limited ourselves in this Article to proposals for change within the context of a tax based on income. Because of the mechanical incoherence of the current Code, the recommendations we have made in Parts II and III have generally been made in the alternative-one approach if the Code as a whole were to be rationalized in a manner consist with ability to pay and a second if it were to retain its current form. This Part collects and summarizes our various recommendations. We first summarize our first-best preferences-proposals for the retention, amendment, or repeal of provisions of particular relevance to people with disabilities if the Code as a whole were to be rationalized in a manner consistent with nonutilitarian notions of ability to pay. Recognizing that this approach may be unrealistic, we then summarize our recommendations within the context of the current Code structure.

A. First-Best: Proposals for the Retention, Amendment, or Repeal of Tax Provisions of Particular Relevance to People with Disabilities Within the Context of an Ability-to-Pay Income Tax

Articulation of a full-blown ability-to-pay individual income tax system is beyond the scope of this Article. The general parameters of

368 See, e.g., Mitchell L. Engler, Progressive Consumption Taxes, 57 Hastings L.J. 55, 55 (2005) ("After years of debate, an academic consensus has emerged that favors the consumption tax ...."). 
such a system, however, would, for the most part, be consistent with those of a well-structured comprehensive tax base system. Computation of an ability-to-pay tax base would begin with comprehensive tax base income, accurately measured. All economic income would be includible; all current costs of producing such income would be currently deductible; all capital costs of producing such income would be amortized over realistic periods. Some initial amount of such income would be exempt from taxation, either by way of a formal zero-rate bracket or by use of the more familiar standard deduction and personal exemption mechanisms. The sole function of these mechanisms, however, would be to exempt some subsistence level of income from taxation. In our view, filing simplification should be accomplished by limiting non-income-measuring deductions to those necessary to measure ability to pay. For this reason, our first-best recommendations assume that the distinction between above-the-line and below-the-line deductions would be abolished. The alternative minimum tax would then become unnecessary.

An ability-to-pay tax system would differ from a comprehensive tax base system in that unusual nondiscretionary expenditures or losses, reflecting real individual differences in ability to pay, would be deductible. As noted in connection with our discussion of the $1966 \mathrm{Ca}-$ nadian Royal Commission on Taxation report, ${ }^{369}$ normal levels of such nondiscretionary expenditures and losses can be dealt with by use of a progressive rate structure. Unusual nondiscretionary expenditures and losses, however, must be deductible-not creditable-if the tax base is accurately to measure ability to pay. It is beyond the scope of this Article to explore which of the many current non-incomemeasuring deductions would be retained in such a system, but as we have noted, Congress already characterizes the medical expense deduction as available only with respect to unusual expenses. The stated purpose of the $7.5 \%$ floor is to prevent the deduction of medical expenses deemed normal at any given level of income. ${ }^{370}$ If personal deductions are allowed only with respect to unusual nondiscretionary expenditures and losses, we would expect similar floors to be instituted with respect to other such deductions. There would be no need for deduction caps or phase-outs, since personal deductions would constitute adjustments necessary to measure true ability to pay. Current credits intended to adjust for ability to pay would be restructured

${ }^{369}$ See supra notes $209-16$ and accompanying text.
See supra note 119. 
as floored deductions. Indeed, with the exception of the foreign tax credit, which helps to define the geographic boundaries of the U.S. income tax, and the earned income credit, which constitutes part of the current system's effective rate structure, all nonbusiness credits could be eliminated. Such a restructuring and reframing would permit a radically simpler individual computational and filing structure.

How then would existing tax provisions of particular relevance to people with disabilities fit within such a system?

As noted in Part III.A.1, the current scope of the general welfare doctrine is unclear. In particular, it is unclear whether the doctrine exempts benefits received in kind rather than cash. In any event, most governmental benefits received in kind-public schooling, police protection, and the like-should remain excludible under an ability-to-pay income tax. Their provision reflects a social decision that such benefits should be treated as non-discretionary. An ability-to-pay system might require that their value be included and then deducted, but it would be simpler just to exclude their value from the outset.

By contrast, cash payments currently excluded under the general welfare doctrine should probably be includible under a wellstructured ability-to-pay income tax. We realize that this recommendation is likely to be controversial and make it only with reservations. The recommendation assumes that a truly adequate core amount of income is excluded from taxation. It also assumes that unusual nondiscretionary expenditures and losses are made fully deductible. If both are true, low-income taxpayers and taxpayers who have incurred unusual expenditures or losses-the bulk of all taxpayers who receive governmental benefits currently excludible under the general welfare doctrine-should remain protected. Consistent with this recommendation and subject to the same reservations and assumptions, SSI, income replacement benefits from accident or health insurance, and income replacement recoveries by reason of personal injury would all become includible.

As noted in Part III.A.6, the current $§ 22$ credit for the elderly and the permanently and totally disabled accomplishes very little and should be repealed. Similarly, the additional standard deduction for the blind, authorized by $\S 63$ (f) (2), is discriminatory and now duplicative of the medical expense deduction insofar as it adjusts for the extra expenses of daily living incurred by taxpayers who are blind; it should therefore also be repealed.

We are agnostic about the continued utility of the disabled access credit of $\S 44$ and the barrier removal deduction of $\S 190$, but would 
make two points with regard to these and other business incentives. First, filing complexity is not as serious an issue for businesses as it is for individuals-businesses are accustomed to complexity, and business tax returns are typically prepared by professionals. Second, transparency and political accountability remain as important in the business context as in any other. Incentive deductions tend to distort reported income; their effective costs tend to be difficult to compute. Credits, by contrast, are transparent and easily tracked. For both these reasons, we do not believe that business credits pose the same threat to the viability and administrability of the tax system that nonincome-measuring deductions authorized for incentive purposes do. Should studies reveal that tax incentives to comply voluntarily with the ADA and similar laws are worth their costs, we would recommend retention of such incentives in credit form.

The $\S 62$ (a) (20) above-the-line deduction for attorney's fees in civil rights and similar actions is fully consistent with comprehensive tax base theory. The first-best ability-to-pay tax system this Subpart assumes would permit the deduction of all current costs of producing income and would eliminate the distinction between above- and below-the-line deductions. Section 62(a) (20) would appear to be unnecessary in such a system and could therefore be repealed. The same is true of the $\S 67(\mathrm{~b})(6)$ exemption of impairment-related work expenses from the $2 \%$ floor. All work expenses would be fully deductible in a first-best ability-to-pay tax system. Only unusual nondiscretionary personal expenditures and losses would be deductible. The $2 \%$ floor would therefore be unnecessary and, in any event, inappropriate to apply to income-measuring expenses.

As we noted in Part III.C.2, the medical expense deduction has evolved to a point where it now authorizes deduction of most of the extra costs people with disabilities must incur in the course of daily living. It would therefore remain an important component of any ability-to-pay tax system as applied to people with disabilities. We recommend one minor change and raise one further issue that we believe does not require statutory change. First, the extra costs incurred by people with disabilities in commuting to and from work should be deductible. All other impairment-related work expenses are already deductible, as are most other extra costs incurred by people with disabilities in the course of daily living. There is no longer any reason to disallow the deduction of the extra costs of commuting required by reason of a taxpayer's disability on the ground that such costs are "personal." 
Second, an ability-to-pay tax system should allow the deduction of all unusual nondiscretionary expenditures and losses. It might be argued that the extra costs of daily living incurred by reason of disability fall into this category and should therefore not be subject to a $7.5 \%$ floor-unlike other medical expenses. ${ }^{371}$ In our view, however, a line between "medical expenses" and extra expenses incurred by reason of disability is not easily drawn. A heart attack or catastrophic accident is arguably just as unusual and just as deserving of exemption from that floor. In addition, privileging the extra expenses incurred by reason of disability over other types of medical expenses may be inconsistent with the appeal to equality norms implicit in both the civil rights and human variation paradigms of disability rights. We therefore would not recommend drawing any such distinction.

Finally, we recommend the retention of the $\S 129$ exclusion of employer-provided dependent care assistance but are agnostic about the merits of the $\S 21$ credit for household and dependent services. Both are intended to adjust for the extra employment-related costs incurred by taxpayers with minor or disabled dependents. In a first-best ability-to-pay tax system, employment-related costs should be deductible; the $\S 129$ exclusion is the equivalent of including and then deducting the employer's contribution. We are agnostic about the $\S 21$ credit because of our view that the costs involved should theoretically be deductible and because of the complicating effects of nonbusiness credits on the individual tax system. At the same time, we acknowledge that the practical difficulties of structuring a deduction that fairly deals with the problem of child care across income classes may be difficult to surmount.

B. Second-Best: Proposals for the Retention, Amendment, or Repeal of Tax Provisions of Particular Relevance to People with Disabilities Within the Context of the Current Income Tax

In the more likely event that we remain stuck with an individual income tax system that looks roughly like our current system or that the Code is overhauled in ways inconsistent with ability to pay, we would retract and revise several of the recommendations summarized above. First, we would retain the general welfare doctrine, both generally and as applied to SSI. The current zero-bracket amount is inadequate and not consistently implemented. In addition, the kinds of losses that are often reimbursed tax-free under the doctrine are cur-

${ }^{371}$ David Duff raised this issue in comments on one of our drafts. 
rently only sporadically deductible, and then only below the line. On the other hand, we would continue to recommend repeal of the $\S 104$ exclusions of income replacement benefits and recoveries, the $\S 22$ credit for the elderly and the permanently and totally disabled, and the $\S 63(\mathrm{f})$ (2) additional standard deduction for the blind. Second, we would retain the $\S 62$ (a) (20) above-the-line deduction for attorney's fees in civil rights and similar actions and the $\$ 67$ (b) (6) exemption of impairment-related work expenses from the $2 \%$ floor. Ideally, impairment-related work expenses should be deductible above the line as well, but we are concerned about the political effects of privileging impairment-related work expenses over other employee expenses.

\section{CONCLUSION}

Tax provisions of particular relevance to people with disabilities pose serious challenges to both disability and tax theory. The problem for disability theorists is that many of the most important such provisions were originally justified by reference to the now-rejected medical/charity paradigm and are inconsistent with a strict civil rights approach. As a practical matter, such provisions remain profoundly important to people with disabilities. Fortunately, the most important such provisions can be reframed in a manner consistent with the new human variation paradigm of disability.

The challenge for mainstream tax theory is much more severe. Mainstream tax theory has always assumed that taxpayers are identical except with respect to income and family status. It is precisely this assumption that the human variation paradigm of disability contests. Wholly apart from any such theoretical disagreement, the reality of disability itself strains this assumption to the breaking point. A quadriplegic's decision to hire a personal assistant to help with bathing and personal hygiene cannot credibly be characterized as just another consumption choice, normatively indistinguishable from a decision to throw a big party. Our moral intuitions, reflected in the expansive modern medical expense deduction, tell us that at equivalent income levels the quadriplegic simply cannot afford to contribute as much to the costs of government as a taxpayer who can bathe and care for herself without assistance.

At the core of these intuitions lies a sense that a taxpayer's ability to pay really does matter. It may be that, as tax theorists have asserted repeatedly over the decades, ability to pay lacks the precision we would prefer in a guiding moral principle. Be that as it may, the 
vast majority of Americans continues to believe it relevant. If tax theory is to be useful, rather than merely "correct" in some academic sense, it has to at least nod in the direction of the electorate's notions of fairness.

We believe it impossible to give a coherent account of tax provisions of particular relevance to people with disabilities without explicitly considering ability to pay. If others disagree, we look forward to reading their competing accounts. More generally, our account of the history of the tension between standard tax theory and popular moral intuitions leads us to conclude that until those tensions are resolved, tax theorists are as likely to contribute to our tax system's incoherence as to resolve it. 